\title{
Recent Progress on Fullerene-Based Materials: Synthesis, Properties, Modifications, and Photocatalytic Applications
}

\author{
Sai Yao ${ }^{1,2}$, Xingzhong Yuan ${ }^{1,2, *}$, Longbo Jiang ${ }^{1,2, *}$, Ting Xiong ${ }^{1,2}$ and Jin Zhang ${ }^{1,2}$ \\ 1 College of Environmental Science and Engineering, Hunan University, Changsha 410082, China; \\ yaosai@hnu.edu.cn (S.Y.); xiongt@hnu.edu.cn (T.X.); zhangjinjodg@gmail.com (J.Z.) \\ 2 Key Laboratory of Environmental Biology and Pollution Control (Hunan University), Ministry of Education, \\ Changsha 410082, China \\ * $\quad$ Correspondence: yxz@hnu.edu.cn (X.Y.); jianglongbo@hnu.edu.cn (L.J.); Tel./Fax: +86-731-88821413 (X.Y.)
}

Received: 12 May 2020; Accepted: 22 June 2020; Published: 30 June 2020

\begin{abstract}
Solar light is an inexpensive energy source making up for energy shortage and solving serious environmental problems. For efficient utilization of solar energy, photocatalytic materials have attracted extensive attention over the last decades. As zero-dimensional carbon nanomaterials, fullerenes $\left(\mathrm{C}_{60}, \mathrm{C}_{70}\right.$, etc. $)$ have been extensively investigated for photocatalytic applications. Due to their unique properties, fullerenes can be used with other semiconductors as photocatalyst enhancers, and also as novel photocatalysts after being dispersed on non-semiconductors. This review summarizes fullerene-based materials (including fullerene/semiconductors and fullerene/non-semiconductors) for photocatalytic applications, such as water splitting, $\mathrm{Cr}$ (VI) reduction, pollutant degradation and bacterial disinfection. Firstly, the optical and electronic properties of fullerene are presented. Then, recent advances in the synthesis and photocatalytic mechanisms of fullerene-based photocatalysts are summarized. Furthermore, the effective performances of fullerene-based photocatalysts are discussed, mainly concerning photocatalytic $\mathrm{H}_{2}$ generation and pollutant removal. Finally, the current challenges and prospects of fullerene-based photocatalysts are proposed. It is expected that this review could bring a better understanding of fullerene-based photocatalysts for water treatment and environmental protection.
\end{abstract}

Keywords: fullerene; visible-light photocatalysis; synthesis; $\mathrm{H}_{2}$ production; wastewater treatment

\section{Introduction}

There is no denying that both environmental issues and the energy crisis are becoming serious threats to the sustainable development of human society, with the endless consumption of fossil fuels and the irregular discharge of anthropogenic action [1,2]. In order to solve these problems, industrial development must concentrate on clean energy alternatives, which reduce environmental pollution. As a renewable energy source, solar energy has been an intriguing option. Photocatalysts are an effective route to utilize solar energy for various chemical reactions, including photocatalytic pollutant degradation, disinfection, selective organic synthesis, reduction of $\mathrm{CO}_{2}$ and $\mathrm{H}_{2}$ generation. This is an attractive technology which could effectually utilize solar energy, generate clean production $\left(\mathrm{H}_{2}\right)$ and remediate the environment. Since the photocatalytic performance of $\mathrm{TiO}_{2}$ for water splitting was proposed for the first time by Fujishima and Honda in 1970s, much work has been done to study the photocatalytic mechanisms and develop novel photocatalysts [3]. Up to date, numerous appealing photocatalysts have been developed and extensively investigated, such as simple oxides ( $\mathrm{ZnO}$ ) [4], metal chalcogenides (CdS) [5], Ag-based compound $\left(\mathrm{Ag}_{3} \mathrm{PO}_{4}\right)$ [6], Bi-based compound $\left(\mathrm{BiVO}_{4}\right.$ and $\mathrm{Bi}_{2} \mathrm{MoO}_{6}$ ) [7,8], MOFs [9] and g- $\mathrm{C}_{3} \mathrm{~N}_{4}$ [10]. In addition to novel photocatalysts, cocatalysts such as 
precious metals (Pt), two-dimensional transition metal sulfides $\left(\mathrm{MoS}_{2}, \mathrm{WS}_{2}\right.$, etc.) and carbonaceous nanomaterials are also widely developed and applied in the field of photocatalysis [11-13].

Since the mid-1990s, carbonaceous nanomaterials have been attracting extensive attention, including fullerene, carbon nanotube (CNT) and graphene [14]. Due to uniquely optical and electrical properties, they have been extensively investigated in photocatalytic applications in the past decades. On one hand, they could enhance the photocatalytic efficiency of other semiconductors after combination. For example, CNTs could induce photocatalytic enhancement via three mechanisms: increasing the surface area, suppressing the recombination of hole $\left(\mathrm{h}^{+}\right)$-electron $\left(\mathrm{e}^{-}\right)$pairs and enhancing the adsorption of visible light) [15]. Similar to CNT, graphene covers all three of the mechanisms of photocatalytic enhancement above. On the other hand, carbonaceous nanomaterials display effective photocatalytic performance on their own without combining with other semiconductors and are applied alone as novel photocatalysts in some cases. For example, Luo, et al. [16] proposed a self-photocatalytic activity of multiwalled nanotubes (MWCNTs) in the visible range after highly defective modification. Moreover, modified graphene oxide (GO) with a band gap of 2.4-4.3 eV exhibits effective $\mathrm{H}_{2}$ generation ability within light illumination (UV or visible), which alone may be regarded as a next-generation photocatalyst $[17,18]$.

Among carbonaceous nanomaterials, fullerene exhibits appealing performances similar to CNT and graphene in the photocatalytic application. In previous studies, extensive attentions have been devoted to exploring the roles that fullerene plays in the photocatalytic processes. It was proven that fullerene can be used not only as a photocatalytic enhancer for other semiconductors but also as a novel photocatalyst itself, after being dispersed on a non-semiconductor support. This is ascribed to its distinct optical, photophysical and photochemical properties. Fullerene, a carbon allotrope, is a kind of zero-dimensional (OD) nanocarbon material discovered by Kroto et al., and it has a closed-cage spherical structure which consists of five-membered and six-membered rings [19]. It is well established that there are various forms of fullerene, such as $C_{60}, C_{70}, C_{76}, C_{82}$ and $C_{84}$. Among these forms, the $C_{60}$ and $\mathrm{C}_{70}$ were more extensively investigated than others. Owing to electron delocalization, fullerenes are used extensively as strong-affinity electron acceptor, and for instance $\mathrm{C}_{60}$ is able to reversibly absorb six electrons [20]. The band gap energy (Eg) of solid fullerenes (such as $\mathrm{C}_{60}, \mathrm{C}_{70}, \mathrm{C}_{84}$ etc.) are from 1.5 to $1.98 \mathrm{eV}$ between the highest occupied molecular orbital (HOMO) and the lowest unoccupied molecular orbital (LUMO) [4]. Ascribed to the narrow Eg, fullerenes have intensive absorption of UV light and moderate but extensive adsorption of visible light, which make them appealing options for photocatalytic application. Additionally, fullerenes have been previously reported as an excellent photosensitizer as well, with a high quantum efficiency around 1.0 [21]. Fullerene solutions can induce photochemical reactive oxygen species (ROS) generation via two pathways. Under light irradiation (UV or visible), single oxygen $\left({ }^{1} \mathrm{O}_{2}\right)$ will be formed in fullerene-toluene solution (pathway II), and superoxide anion radical $\left(\mathrm{O}_{2}^{-\bullet}\right)$ and hydroxyl radical $(\bullet \mathrm{OH})$ can be generated in solvent in the presence of electron donors such as ethylenediamine tetraacetic acid (EDTA) and nicotinamide adenine dinucleotide (NADH) [22]. Typically, ROS is a class of active materials that easily induce chemical reaction, which could play an effective role in photocatalytic application. However, easy aggregation is the main obstacle of fullerene in water treatment applications, which suppresses the photoactivity of fullerene. Namely, when dispersed in water, fullerene tends to form nanoscale aggregates (termed $\mathrm{nC}_{60}$, $\mathrm{nC}_{70}$, etc.) with the quenching of excited states of neighboring fullerene molecules which are brought into close contact via aggregation. For retaining fullerene's photoactivity in aqueous systems, it is necessary for immobilization of fullerene onto solid supports.

Nowadays, many fullerene-semiconductor materials have been successfully built for photocatalytic applications, such as $\mathrm{TiO}_{2} / \mathrm{C}_{60}\left(\mathrm{C}_{70}\right), \mathrm{ZnO} / \mathrm{C}_{60}, \mathrm{CdS} / \mathrm{C}_{60}$ and $\mathrm{C}_{3} \mathrm{~N}_{4} / \mathrm{C}_{60}\left(\mathrm{C}_{70}\right)$ [23-25]. These photocatalysts have been extensively investigated in photocatalytic pollutant degradation, disinfection and water splitting for $\mathrm{H}_{2}$ evolution. Note that fullerene can obviously enhance the photocatalytic efficiency. At the same time, a variety of fullerene-support (non-semiconductor) materials were successfully fabricated and used for photodegradation of organic pollutant, photocatalytic organic 
synthesis and disinfection, such as silica/ $\mathrm{C}_{60}, \gamma-\mathrm{Al}_{2} \mathrm{O}_{3} / \mathrm{C}_{60}, \mathrm{MCM}-41 / \mathrm{C}_{70}$ and polysiloxane-supported fullerene derivative [26-28]. Apart from high-efficient photocatalytic activity, these photocatalysts not only exhibited more stable than the pristine fullerene in solution but also had superior recyclability.

Previously, Yeh, Cihlář, Chang, Cheng and Teng [13] have reviewed the roles of graphene oxide (GO) in photocatalytic water splitting, which mainly introduces strategies for tuning the electronic structure of GO for photocatalytic water splitting. Gangu, Maddila and Jonnalagadda [15] have reported a review on the MWCNTs mediated semiconducting materials as photocatalysts in water treatment. In another review, Ge, Zhang and Park [14] have discussed recent advances in carbonaceous photocatalysts and the developmental direction for them, such as activated carbon, carbon dots, carbon nanotubes, graphene and fullerene. To our knowledge, no papers have reviewed the fullerene/semiconductor and fullerene/support photocatalysts for wastewater treatment and water splitting. Therefore, the present review provides a comprehensive understanding of fullerene-based photocatalysts, including fullerene/semiconductor photocatalysts and fullerene/support photocatalysts. The optical, photochemical and electronic properties of fullerene are generally presented. Then, recent advances in the synthesis methods and photocatalytic application of fullerene-based photocatalysts are summarized. Meanwhile, the photocatalytic efficiency of these-prepared photocatalysts are discussed in wastewater treatment and water splitting for $\mathrm{H}_{2}$ evolution, wherein the mechanisms of the fullerene-based photocatalysts are underlined in detail. In the end, the current challenges and prospects of fullerene-based photocatalysts are proposed.

\section{Role of Fullerene}

\subsection{Basic Principles of Semiconducting Photocatalysis}

In the photocatalytic procedure of semiconductors, there are three main factors, i.e., light resources, photocatalysts and reaction mediums [14]. The photocatalytic process could be initiated only by the light (i.e., UV, infrared and visible light) with energy equal to or over the band gap energy (Eg) of the photocatalyst. Typically, it could be briefly presented as follows. Upon irradiation by light resource, the electrons in the valence band (VB) could be excited to the conduction band (CB) of the photocatalyst and holes leave in $\mathrm{VB}$, resulting in the separation of photogenerated hole-electron pairs. Immediately, most of them recombine with heat generation while a small fraction can transfer to the semiconductor's surface to induce redox reactions. Generally, for photocatalytic decontamination, the separated holes and electrons of the semiconductor can react with ambient substances (i.e., $\mathrm{H}_{2} \mathrm{O}$ and $\mathrm{O}_{2}$ ) to produce free radicals (i.e., $\bullet \mathrm{OH}, \bullet \mathrm{O}_{2}{ }^{-}, \mathrm{HO}_{2} \bullet, \mathrm{H}_{2} \mathrm{O}_{2}$ ). Then, the highly oxidative holes and reactive radicals will intensively degrade organic pollutants into small molecules or inorganic materials through addition/substitution reaction and electron transfer between contaminants and free radicals [29]. Through the processes above, the pollution is mitigated or eliminated. Compared with pollutant degradation, the photocatalytic $\mathrm{H}_{2}$ generation over semiconductor share some similarities. In detail, the generating processes of the photoinduced charges and formation of partial radicals are identical between pollutant degradation and $\mathrm{H}_{2}$ generation. The difference in photocatalytic $\mathrm{H}_{2}$ generation is that photoinduced charges react with $\mathrm{H}^{+}$adsorbed on the photocatalyst or in surroundings to produce $\mathrm{H}_{2}$ rather than $\bullet \mathrm{O}_{2}{ }^{-}$[30]. In this process, additives are usually required to facilitate the efficiency of photocatalytic $\mathrm{H}_{2}$ generation, such as hole scavenger and (or) sacrificial donor.

In the past decades, a number of semiconductors were developed for photocatalysis applications, such as $\mathrm{TiO}_{2}, \mathrm{ZnO}, \mathrm{CdS}$, Ag-based semiconductors, Bi-based semiconductors and g- $\mathrm{C}_{3} \mathrm{~N}_{4}$. However, many problems limit the photocatalytic efficiency of the current photocatalysts, including insufficient visible light utilization, wide bandgap, rapid recombination of photoinduced holes and electrons and poor stability. Various strategies were proved to be effective in enhancing the photocatalytic activity, such as morphology control, element doping, heterojunction construction and coupling with carbonaceous nanomaterials [10]. 


\subsection{The Role of Fullerene in Semiconductor/Fullerene Photocatalysts}

For effective semiconductor/fullerene photocatalysts, the introduction of fullerene generally enhances the photocatalytic performance through various aspects as follows. For instance, fullerene could capture electrons from $\mathrm{CB}$ of semiconductor due to its high-affinity for electrons, which significantly retard the recombination of photoinduced hole-electron pairs [31,32]. As a result, more separated photogenerated holes and electrons could take part in photocatalytic reaction, increasing photocatalytic efficiency. Then, fullerene could enhance the light absorption (both UV and visible light) because it is an excellent photo-response material (300 700 nm), wherein elevated light energy utilization excites more electrons from VB to CB [33,34]. In respect to photo-response characteristics, it must also be mentioned that fullerene could not shift the adsorption edge of pristine photocatalyst unless the introduction of fullerene changed the structure of semiconductor [35-37]. In other words, if the fullerene does not change the crystalline structure of semiconductor in the synthesis procedure, which was typically affected by a stronger bonding force other than simply physically blending, it could not change the conduction band (Eg) at all. Undoubtedly, the introduction of fullerene could change the specific surface area BET (Brunauer-Emmett-Teller), while it does not always present the same results of change trend. In previous studies, it increased or decreased the BET of the photocatalyst depending on the specific situation [38-40]. So, it was controversial that the fullerene enhances the BET of photocatalyst to contribute to high adsorption ability for reactant.

Fullerene is virtually insoluble in water, but soluble in nonpolar organic solvents, such as toluene and 1,2-dichlorobenzen [41]. Hence, it performs a good stability in water solution. After dissolved in nonpolar solvent, fullerene could be coupled with semiconductor to form stable semiconductor/fullerene composite by various methods, wherein no fullerene is leached out even after the as-prepared composite is repeatedly rinsed with the aforementioned solvent. Additionally, fullerene exhibits superior potentials for stabilizing semiconductors which deeply suffers photocorrosion, such as $\mathrm{ZnO}, \mathrm{CdS}$ and $\mathrm{Ag}_{3} \mathrm{PO}_{4}$. For example, a significant increase of stabilization was observed for $\mathrm{ZnO} / \mathrm{C}_{60}$ nanocomposite in previous studies [42]. The photogenerated holes of $\mathrm{ZnO}$ could easily react with surface oxygen atoms during the photocatalysis process, leading to fast decline of photocatalytic activity. When $\mathrm{C}_{60}$ was covered on $\mathrm{ZnO}$, the activity of surface oxygen atoms was effectively reduced so that photocorrosion effect was effectively inhibited. Similarly, high stabilization of $\mathrm{AgPO}_{4} / \mathrm{C}_{60}$ was also observed, because $\mathrm{C}_{60}$ could obviously suppress the transform of $\mathrm{Ag}^{+}$into $\mathrm{Ag}$ of bare $\mathrm{Ag}_{3} \mathrm{PO}_{4}$ composite [6]. Moreover, Cai, et al. [43] fabricated $\mathrm{CdS} / \mathrm{C}_{60}$ nanocomposite in which $\mathrm{C}_{60}$ has shown effectively inhibition of photocorrosion of CdS. In order to estimate the stability of the as-prepared sample, the released $\mathrm{Cd}^{2+}$ concentration was determined in remaining solution after three cycles for rhodamine $(\mathrm{RhB})$ degradation. The $\mathrm{Cd}^{2+}$ concentration was $381.3 \mu \mathrm{g} / \mathrm{L}$ in solution with naked CdS while it was $51.9 \mu \mathrm{g} / \mathrm{L}$ in solution with $0.4 \mathrm{C}_{60} / \mathrm{CdS}$ nanocomposite, and the former was 7.3-times of the later. This means that $\mathrm{C}_{60}$ could effectively inhibit the photocorrosion to enhance the stability of CdS.

\section{Synthesis of Semiconductor/Fullerene Photocatalysts}

A number of fullerene/semiconductors $\left(\mathrm{TiO}_{2}, \mathrm{ZnO}, \mathrm{CdS}, \mathrm{C}_{3} \mathrm{~N}_{4}\right.$, etc.) have been fabricated for photocatalytic wastewater treatment and water splitting. It is unquestionable that synthetic process plays an important role in determining the size, morphology and physicochemical characteristic of a photocatalyst. Fullerene/semiconductor photocatalysts can be constructed via a series of synthetic methods, including simple adsorption, hydrothermal/solvothermal synthesis, sol-gel procedure and mechanical ball-milling. These synthetic methods are summarized and illustrated briefly as follows.

\subsection{Simple Adsorption Method}

Simple adsorption method has been extensively used to fabricate semiconductor/fullerene nanocomposites. This procedure is cost-effective without complicated external condition. It is well established that pure fullerene $\left(\mathrm{C}_{60}\right.$ or $\left.\mathrm{C}_{70}\right)$ is extremely hydrophobic but dissolves in some 
organic solvents (benzene, toluene, 1,2-dichlorobenzen etc.), which are mainly used to dissolve fullerene for preparing fullerene/semiconductor photocatalysts [4,44]. Typically, the semiconductor is added into the fullerene solution to form adequately dispersed suspensions, and then the newly generating fullerene/semiconductor nanocomposite is obtained through evaporating the solvent. Many semiconductor/fullerene nanocomposites have been synthesized through this method, such as $\mathrm{TiO}_{2} / \mathrm{C}_{60}$, $\mathrm{ZnO} / \mathrm{C}_{60}$, Bi-based oxides $/ \mathrm{C}_{60}$ and $\mathrm{C}_{3} \mathrm{~N}_{4} / \mathrm{C}_{60}$ [45-47]. Note that the simple adsorption method differs from direct mechanical mixture, because no fullerene is leached out when the nanocomposite is added into the aforementioned organic solvent.

\subsection{Hydrothermal Synthesis Method}

Hydrothermal synthesis is an appealing method for preparing semiconductor/fullerene nanomaterials. In the synthetic procedure, pretreatment of fullerene is imperative and acid-treatment is extensively applied to produce several oxygen-containing active sites on the surface of fullerene. For instance, nitric acid is a common agent to oxide fullerene under reflux condition, further facilitating more efficient combination of fullerene with other semiconductors through hydrothermal procedure. $\mathrm{Yu}$, et al. [48] constructed $\mathrm{TiO}_{2} / \mathrm{C}_{60}$ nanocomposite using this acid-treated $\mathrm{C}_{60}$ via a hydrothermal method. Activated $\mathrm{C}_{60}$ and $\mathrm{Ti}\left(\mathrm{OC}_{4} \mathrm{H}_{9}\right)_{4}$ (titanium source) were mixed into ethanol/water solution $(1: 2 \mathrm{v} / \mathrm{v})$ and then the reaction mixture solution was transferred into stainless steel autoclave at $180{ }^{\circ} \mathrm{C}$ for $10 \mathrm{~h}$. Similarly, $\mathrm{TiO}_{2} / \mathrm{C}_{70}$ was fabricated by a hydrothermal procedure as well [49]. Very recently, several semiconductor/fullerene photocatalysts were obtained by the hydrothermal method, such as $\mathrm{CdS} / \mathrm{C}_{60}, \mathrm{PbMoO}_{4} / \mathrm{C}_{60}, \mathrm{BiOCl} / \mathrm{C}_{70}$ and $\mathrm{C}_{3} \mathrm{~N}_{4} /\left(\mathrm{C}_{60}, \mathrm{C}_{70}\right)[50,51]$. For example, $\mathrm{Cai}, \mathrm{Hu}$, Zhang, $\mathrm{Li}$ and Shen [43] constructed $\mathrm{CdS} / \mathrm{C}_{60}$ photocatalyst via a facile one-pot hydrothermal method,

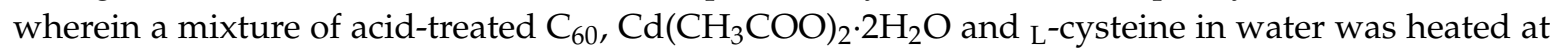
$200{ }^{\circ} \mathrm{C}$ for $10 \mathrm{~h}$ in autoclave. Moreover, $\mathrm{Ma}$, Zhong, Li, Wang and Peng [39] synthesized BiOCl/C 70 photocatalyst via a hydrothermal method and the procedure was presented as follow. Acid-treated $\mathrm{C}_{70}$ and $\mathrm{Bi}\left(\mathrm{NO}_{3}\right)_{3} \cdot 5 \mathrm{H}_{2} \mathrm{O}$ were dissolved in glacial acetic acid and $\mathrm{KCl}$ solution was slowly added into, and then the mixture solution was transferred into stainless autoclave maintaining at $180^{\circ} \mathrm{C}$ for $24 \mathrm{~h}$.

In addition to nitric acid, meta-chloroperoxybenzoic acid (MCPBA) is an effectively alternative oxidizing agent to pretreat fullerene before hydrothermal method. Typically, fullerene and MCPBA are dissolved into benzene, followed by heating reflux for hours to activated the surface of fullerene. For instance, $\mathrm{CoS} / \mathrm{C}_{60}$ nanocomposite was prepared by using the MCPBA-oxidized $\mathrm{C}_{60}$ via hydrothermal method [52]. Namely, MCPBA-oxidized $\mathrm{C}_{60}, \mathrm{CoCl}_{2}$ and $\mathrm{Na}_{2} \mathrm{~S}_{2} \mathrm{O}_{3}$ mixture water solution was heated at $150{ }^{\circ} \mathrm{C}$ for $12 \mathrm{~h}$ in autoclave, and the $\mathrm{CoS} / \mathrm{C}_{60}$ nanocomposite was obtained through filter. Similarly, other semiconductor/fullerene nanocomposites were prepared via hydrothermal method with MCPBA-oxidized $\mathrm{C}_{60}$, including $\mathrm{CdSe} / \mathrm{C}_{60}$ and $\mathrm{WO}_{3} / \mathrm{C}_{60}[36,53]$.

\subsection{Ball Milling Method}

Ball-milling is a facile and eco-friendly method to structure solid-solid composites, which could generate stronger intermolecular interactions than physical blends. Recently, the hybridized $\mathrm{MoS}_{2} / \mathrm{C}_{60}$ nanocomposite was obtained through a planetary ball-milling machine [54]. Mixture of $\mathrm{MoS}_{2}$ and $\mathrm{C}_{60}$ powders was transferred into a ball-milling jar together with stainless steel balls under $\mathrm{Ar}$ atmosphere. After operation at $500 \mathrm{rmp}$ for $48 \mathrm{~h}$, the reactant was Soxhlet extracted by $\mathrm{CS}_{2}$ to remove the unreacted $C_{60}$. The strong van der Waals (vdW) interactions contributed to formation of $\mathrm{MoS}_{2} / \mathrm{C}_{60}$ heterostructure rather than a covalent conformation, resulting in elevated photocatalytic activity of pure $\mathrm{MoS}_{2}$. In addition, a g- $\mathrm{C}_{3} \mathrm{~N}_{4} / \mathrm{C}_{60}$ nanocomposite was fabricated via a ball-milling route as well [55]. Additional $\mathrm{LiOH}$ was needed as a catalyst before ball-milling process and the detailed synthetic process of the g- $\mathrm{C}_{3} \mathrm{~N}_{4} / \mathrm{C}_{60}$ was presented in Figure 1. It was firstly proposed in fullerene chemistry that the covalent bonding forms via a four-membered ring of azetidine between $\mathrm{C}_{60}$ and $\mathrm{g}-\mathrm{C}_{3} \mathrm{~N}_{4}$ nanosheets. The $\mathrm{LiOH}$ as catalyst breaks $\pi-\pi$ carbon bonds of $\mathrm{C}_{60}$ to produce $\mathrm{C}_{60}$ radicals, then ball-milling activates g- $\mathrm{C}_{3} \mathrm{~N}_{3}$ and results in the covalent reaction between g- $\mathrm{C}_{3} \mathrm{~N}_{4}$ and $\mathrm{C}_{60}$ (Figure 1). 


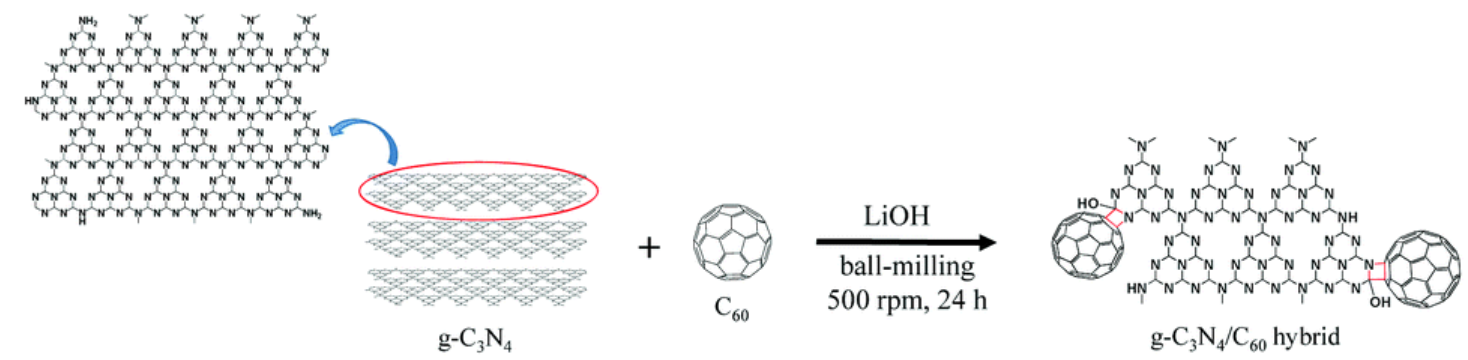

Figure 1. Schematic illustration of the mechanochemical reaction between $g-C_{3} N_{4}$ and $C_{60}$ in the presence of the $\mathrm{LiOH}$ catalyst in a sealed ball-mill crusher. Reproduced with permission from Reference [55]. Copyright 2017, RSC.

\subsection{Other Techniques}

Sol-gel approach has been used to prepare fullerene- $\mathrm{TiO}_{2}$-semiconductor ternary photocatalysts. Meng, et al. [56] fabricated CdS- $\mathrm{C}_{60} / \mathrm{TiO}_{2}$ photocatalyst by a sol-gel method. Firstly, $\mathrm{NaS}_{2}$ solution was dropwise added into oxidized $\mathrm{C}_{60}$ and $\left(\mathrm{CH}_{3} \mathrm{COO}\right)_{2} \mathrm{Cd} \cdot 2 \mathrm{H}_{2} \mathrm{O}$ mixed ethanol solution and the collected solids were calcinated at $300^{\circ} \mathrm{C}$ to obtain CdS- $\mathrm{C}_{60}$ particles. Then, $\mathrm{CdS}-\mathrm{C}_{60}$ particles were added into titanium (IV) n-butoxide (TNB) solution with constant stirring and $\mathrm{CdS}-\mathrm{C}_{60} / \mathrm{TiO}_{2}$ gels were produced in mixed solution under reflux at $70{ }^{\circ} \mathrm{C}$. Finally, the $\mathrm{CdS}-\mathrm{C}_{60} / \mathrm{TiO}_{2}$ nanoparticles were obtained after heat treatment at $400{ }^{\circ} \mathrm{C}$. Bai, Wang, Wang, Yao and Zhu [35] proposed a facile thermal treatment method for fabricating $\mathrm{g}-\mathrm{C}_{3} \mathrm{~N}_{4} / \mathrm{C}_{60}$ photocatalyst. The procedure was presented as follow: ball-milled $\mathrm{C}_{60}$ and dicyandiamide mixture was transferred into a muffle furnace and held at $550{ }^{\circ} \mathrm{C}$ for $4 \mathrm{~h}$. Moreover, Li and Ko [57] successfully prepared $\mathrm{MoS}_{2} / \mathrm{C}_{60}$ nanocomposite by a facile heating treatment procedure. The wetness impregnation method is also an effective method for building semiconductor/fullerene photocatalysts. Apostolopoulou, et al. [58] prepared $\mathrm{TiO}_{2} / \mathrm{C}_{60}$ nanoparticles using 1,2-dichloro-benzene as a solvent via a successive incipient wetness impregnation followed by heating at $180^{\circ} \mathrm{C}$. Similarly, a polyhydroxyfullerene (PHF)/titanium dioxide nanotube was prepared by incipient wetness impregnation [59]. Firstly, fullerene was functionalized by $\mathrm{NaOH}$ and $\mathrm{H}_{2} \mathrm{O}_{2}$ to obtain PHF (or called fullerenol). Then, PHF was added to $\mathrm{TiO}_{2}$ nanotube solution under a wetness impregnation followed by heating at $400^{\circ} \mathrm{C}$. Hence, this provides a new route for coupling fullerenol with other semiconductors to obtain effective photocatalysts.

\section{The Photocatalytic Application of Fullerene/Semiconductor Photocatalysts}

The fullerene/semiconductor photocatalysts have been extensively used for photocatalytic wastewater treatment (pollutant degradation, $\mathrm{Cr}(\mathrm{VI})$ reduction, disinfection etc.) and water splitting for $\mathrm{H}_{2}$ generation [49,60,61]. Among them, photocatalytic degradation of organic pollutant is ascribed to decomposition of organic molecule structure and photocatalytic disinfection depends on inactivation of microorganisms. However, photocatalytic $\mathrm{Cr}(\mathrm{VI})$ reduction focuses on the transformation from $\mathrm{Cr}(\mathrm{VI})$ to $\mathrm{Cr}$ (III). It is generally believed that chromium $(\mathrm{Cr})$ is among the sixteen most toxic contaminants due to its carcinogenic and teratogenic effect on human. Hence, the World Health Organization (WHO) and the United State Environmental Protection Agency (USEPA) have set the maximum permissible concentration of $\mathrm{Cr}$ in drinking water at $0.05 \mathrm{mg} / \mathrm{L}$ and $0.1 \mathrm{mg} / \mathrm{L}$ [62]. Note that the reduced $\mathrm{Cr}$ (III) is far less toxic and more stable than $\mathrm{Cr}(\mathrm{VI})$, so the photocatalytic $\mathrm{Cr}(\mathrm{VI})$ reduction is a promising method to reduce the chromium toxicity in water.

Furthermore, Tables 1 and 2 summarize the photocatalytic efficiency in pollutant degradation and $\mathrm{H}_{2}$ generation over all kinds of fullerene/semiconductor photocatalysts, respectively. Next, detailed photocatalytic activity and mechanisms will be discussed for various types of semiconductor/fullerene photocatalysts, which is accompanied with analyses of electron transfer routes, free radical reactions and stability of photocatalysts. 


\subsection{Fullerene Based $\mathrm{TiO}_{2}$ Photocatalysts}

$\mathrm{TiO}_{2}$ is the most extensively used photocatalyst due to its easy availability, strong oxidizing ability, and superior photoelectronic properties [63,64]. With a wide band gap $(\sim 3.2 \mathrm{eV}), \mathrm{TiO}_{2}$ could only be excited under UV light, which limits efficient utilization of solar light [65]. Meanwhile, the fast recombination of photoinduced hole-electron pairs restricts the photocatalytic efficiency of $\mathrm{TiO}_{2}$ [66]. It has been proven that coupling fullerene with $\mathrm{TiO}_{2}$ is a helpful way to boost the photocatalytic efficiency of pure $\mathrm{TiO}_{2}$ both under $\mathrm{UV}$ light and visible light irradiation.

Oh, et al. [67] prepared $\mathrm{TiO}_{2} / \mathrm{C}_{60}$ photocatalyst by a heat treatment method with $700{ }^{\circ} \mathrm{C}$. It was shown that the $\mathrm{TiO}_{2} / \mathrm{C}_{60}$ exhibited a more significant effect towards $\mathrm{MB}$ degradation with an increase of $-\ln \left(\mathrm{C} / \mathrm{C}_{0}\right)$ values than that of the original $\mathrm{TiO}_{2}$ under UV light illumination. Yu, Ma, Liu and Cheng [48] successfully fabricated mesoporous $\mathrm{TiO}_{2} / \mathrm{C}_{60}$ powders via a hydrothermal method, which demonstrated that $\mathrm{C}_{60}$ molecules could be dispersed as monolayer or few layers onto bimodal mesoporous $\mathrm{TiO}_{2}$ via covalent bonding. The $0.5 \mathrm{wt} \% \mathrm{TiO}_{2} / \mathrm{C}_{60}$ exhibited the best photocatalytic efficiency for acetone decomposition under UV light irradiation and the degradation rate constant $(\mathrm{k})$ was $13.9 \times 10^{-3}$, reaching 3.3-times that of the pure $\mathrm{TiO}_{2}$. In this UV-light-driven photocatalytic system, the dominant role of $\mathrm{C}_{60}$ is an inhibitor of rapid recombination of photogenerated hole-electron pairs, leading to boost the quantum efficiency of $\mathrm{TiO}_{2}$. With respect to $\mathrm{TiO}_{2} / \mathrm{C}_{60}$ photocatalyst, the excited electrons will transfer from $\mathrm{TiO}_{2}$ to $\mathrm{C}_{60}$ because the conduction band potential of $\mathrm{TiO}_{2}\left(-0.5 \mathrm{~V}\right.$ vs. NHE) is more negative than that of $\mathrm{C}_{60} / \mathrm{C}_{60}{ }^{\circ-}$ $(-0.2 \mathrm{~V}$ vs. NHE). Under UV light irradiation, the photogenerated electrons are excited from the VB of $\mathrm{TiO}_{2}$ to the $\mathrm{CB}$, leaving holes in the VB. Generally, these holes and electrons incline to fast recombination and only partial carriers take part in redox. However, after $\mathrm{C}_{60}$ is tightly coupled with $\mathrm{TiO}_{2}$, excited electrons could further transfer to $\mathrm{C}_{60}$ due to its excellent electron adsorption capacity, which effectively inhibits recombination of photoinduced carriers and supplies more carriers participating in photocatalytic reaction. Besides, $\mathrm{C}_{60}$ derivative $\left(\mathrm{C}_{60}(\mathrm{CHCOOH})_{2}\right)$ modified $\mathrm{TiO}_{2}$ nanoparticles fabricated by $\mathrm{Mu}$, Long, Kang and $\mathrm{Mu}$ [61] showed superior photocatalytic efficiency in $\mathrm{Cr}$ (VI) reduction under UV light illumination. Compared with pristine $\mathrm{TiO}_{2}$, the $\mathrm{C}_{60}$-derivative-modified $\mathrm{TiO}_{2}$ nanocomposites exhibited a higher photocatalytic efficiency of $97 \%$ for $\mathrm{Cr}(\mathrm{VI})$ reduction within $1.5 \mathrm{~h} \mathrm{UV}$ irradiation. The electron transfer and radical formation procedure is presented as follows, in Equations (1)-(3):

$$
\begin{gathered}
\mathrm{TiO}_{2} / \mathrm{C}_{60}{ }^{h} \rightarrow{ }^{v} \mathrm{C}_{60}\left(\mathrm{e}^{-}\right) / \mathrm{TiO}_{2}\left(\mathrm{~h}^{+}\right) \\
\mathrm{TiO}_{2}\left(\mathrm{~h}^{+}\right)+\mathrm{OH}^{-} \rightarrow \mathrm{TiO}_{2}+{ }^{\bullet} \mathrm{OH} \\
\mathrm{C}_{60}\left(\mathrm{e}^{-}\right)+\mathrm{O}_{2} \rightarrow \mathrm{C}_{60}+{ }^{\bullet} \mathrm{O}_{2}^{-}
\end{gathered}
$$


Table 1. Summary of fullerene based photocatalysts for pollutant degradation.

\begin{tabular}{|c|c|c|c|c|c|c|}
\hline $\begin{array}{l}\text { Photocatalyst } \\
\text { (Additive Amount) }\end{array}$ & $\begin{array}{l}\text { Synthesis Method } \\
\text { (Fullerene Content) }\end{array}$ & Pollutants & $\begin{array}{c}\text { Experimental Conditions } \\
\text { (Light Source, Pollutant } \\
\text { Concentration and React } \\
\text { Time) }\end{array}$ & $\begin{array}{l}\text { Photocatalytic } \\
\text { Activity }\end{array}$ & Enhancement Factor & Reference \\
\hline $\begin{array}{l}\mathrm{TiO}_{2} / \mathrm{C}_{60} \\
(1 \mathrm{~g} / \mathrm{L})\end{array}$ & $\begin{array}{l}\text { In-situ growth } \\
\quad(2.0 \mathrm{wt} \%)\end{array}$ & Methylene blue (MB) & $\begin{array}{c}\text { UV irradiation, } \\
1.0 \times 10^{-4} \mathrm{~mol} / \mathrm{L}, 60 \mathrm{~min}\end{array}$ & $99 \%$ & around $75 \%$ for $\mathrm{TiO}_{2}$ & [67] \\
\hline $\begin{array}{c}\mathrm{TiO}_{2} / \mathrm{C}_{60} \\
(1 \mathrm{~g} / \mathrm{L})\end{array}$ & $\begin{array}{c}\text { Ultrasonication-evaporation } \\
(1.0 \mathrm{wt} \%)\end{array}$ & RhB & $\begin{array}{l}500 \mathrm{~W} \text { Xe-lamp (>400 nm), } \\
10 \mathrm{mg} / \mathrm{L}, 150 \mathrm{~min}\end{array}$ & $95 \%$ & below $5 \%$ for $\mathrm{TiO}_{2}$ & [68] \\
\hline $\begin{array}{l}\mathrm{TiO}_{2} / \mathrm{C}_{70} \\
(1 \mathrm{~g} / \mathrm{L})\end{array}$ & $\begin{array}{l}\text { Hydrothermal synthesis } \\
\qquad(8.5 \mathrm{wt} \%)\end{array}$ & Sulfathiazole & $\begin{array}{c}300 \mathrm{~W} \text { Xenon lamp } \\
(>420 \mathrm{~nm}), 10 \mathrm{mg} / \mathrm{mL}, \\
180 \mathrm{~min}\end{array}$ & $80 \%$ & $10 \%$ for $\mathrm{TiO}_{2}$ & [69] \\
\hline $\begin{array}{l}\mathrm{ZnO} / \mathrm{C}_{60} \\
(0.5 \mathrm{~g} / \mathrm{L})\end{array}$ & $\begin{array}{l}\text { Simple adsorption } \\
(1.5 \mathrm{wt} \%)\end{array}$ & MB & $\begin{array}{c}8 \mathrm{~W} \text { UV lamp }(\lambda=254 \mathrm{~nm}), \\
8 \mathrm{mg} / \mathrm{L}\end{array}$ & $\mathrm{k}=0.0569 \mathrm{~min}^{-1}$ & 3-times than $\mathrm{ZnO}$ & [70] \\
\hline $\begin{array}{l}\mathrm{ZnO} / \mathrm{C}_{60} \\
(0.83 \mathrm{~g} / \mathrm{L})\end{array}$ & $\begin{array}{l}\text { Chemical vapor } \\
(16.7 \mathrm{wt} \%)\end{array}$ & Phenol & $\begin{array}{l}1500 \mathrm{~W} \text { xenon lamp } \\
\text { simulating solar light, } \\
20 \mathrm{mg} / \mathrm{L}\end{array}$ & $\mathrm{k}=0.160 \mathrm{~min}^{-1}$ & 1.22-times than $\mathrm{ZnO}$ & [42] \\
\hline $\begin{array}{l}\mathrm{ZnFe}_{2} \mathrm{O}_{4} @ \mathrm{C}_{60} \\
(1 \mathrm{~g} / \mathrm{L})\end{array}$ & Hydrothermal synthesis & Norfloxacin & $\begin{array}{l}\text { Solar irradiation, } 20 \mathrm{~mL} \text { of } 50 \\
\text { ppm norfloxacin, } 90 \mathrm{~min}\end{array}$ & $85 \%$ & $60 \%$ for $\mathrm{ZnFe}_{2} \mathrm{O}_{4}$ & [71] \\
\hline $\begin{array}{c}\text { ZnAlTi-LDH@C } \mathrm{C}_{60} \\
(\mathrm{ZnAlTi}-\mathrm{LDO}) 0.5 \mathrm{~g} / \mathrm{L}\end{array}$ & Precipitation (5\%) & Bisphenol A (BPA) & $\begin{array}{l}300 \mathrm{~W} \text { xenon lamp simulating } \\
\text { visible light, } 10 \mathrm{mg} / \mathrm{L}, 60 \mathrm{~min}\end{array}$ & $80 \%$ & $\begin{array}{l}\text { below } 10 \% \text { for } \\
\text { ZnAlTi-LDH }\end{array}$ & [38] \\
\hline $\begin{array}{c}\mathrm{CdS} / \mathrm{C}_{60} \\
(1 \mathrm{~g} / \mathrm{L})\end{array}$ & $\begin{array}{l}\text { One-pot hydrothermal } \\
\text { method }(0.4 \mathrm{wt} \%)\end{array}$ & RhB & $\begin{array}{c}300 \mathrm{~W} \text { xenon lamp }(>420 \mathrm{~nm}) \\
20 \mathrm{~mL}, 10 \mathrm{ppm} \text { of } \mathrm{RhB}\end{array}$ & $\mathrm{k}=0.089 \mathrm{~min}^{-1}$ & 1.5-times than CdS & [43] \\
\hline $\begin{array}{l}\mathrm{C}_{3} \mathrm{~N}_{4} / \mathrm{C}_{60} \\
(0.6 \mathrm{~g} / \mathrm{L})\end{array}$ & $\begin{array}{l}\text { Simple adsorption } \\
\quad(1.0 \mathrm{wt} \%)\end{array}$ & RhB & $\begin{array}{c}500 \mathrm{~W} \text { xenon lamp }(>420 \mathrm{~nm}) \\
50 \mathrm{~mL}, 1.0 \times 10^{-5} \mathrm{~mol}^{-1} \\
\mathrm{RhB}, 60 \mathrm{~min}\end{array}$ & $97 \%$ & $54 \%$ for $\mathrm{C}_{3} \mathrm{~N}_{4}$ & [45] \\
\hline $\begin{array}{l}\mathrm{g}-\mathrm{C}_{3} \mathrm{~N}_{4} / \mathrm{C}_{60} \\
(0.5 \mathrm{~g} / \mathrm{L})\end{array}$ & Calcination $(0.03$ wt \%) & MB, phenol & $\begin{array}{c}500 \mathrm{~W} \text { xenon lamp }(>420 \mathrm{~nm}) \\
\mathrm{MB}(50 \mathrm{~mL}, 0.01 \mathrm{mM}), \text { phenol } \\
\quad(50 \mathrm{~mL}, 5 \mathrm{ppm}) .\end{array}$ & $\begin{array}{l}\mathrm{k}_{1}=1.036 \mathrm{~h}^{-1} \\
\mathrm{k}_{2}=0.093 \mathrm{~h}^{-1}\end{array}$ & $\begin{array}{l}\text { 3.2- and 2.9-times } \\
\text { than } \mathrm{C}_{3} \mathrm{~N}_{4}\end{array}$ & [35] \\
\hline
\end{tabular}


Table 1. Cont.

\begin{tabular}{|c|c|c|c|c|c|c|}
\hline $\begin{array}{l}\text { Photocatalyst } \\
\text { (Additive Amount) }\end{array}$ & $\begin{array}{l}\text { Synthesis Method } \\
\text { (Fullerene Content) }\end{array}$ & Pollutants & $\begin{array}{c}\text { Experimental Conditions } \\
\text { (Light Source, Pollutant } \\
\text { Concentration and React } \\
\text { Time) }\end{array}$ & $\begin{array}{l}\text { Photocatalytic } \\
\text { Activity }\end{array}$ & Enhancement Factor & Reference \\
\hline $\begin{array}{l}\mathrm{Ag}_{3} \mathrm{PO}_{4} / \mathrm{C}_{60} \\
(0.5 \mathrm{~g} / \mathrm{L})\end{array}$ & Precipitation $(2.0 \mathrm{wt} \%)$ & Acid red 18 (AR18) & $\begin{array}{c}400 \mathrm{~W} \text { halogen lamp } \\
(420-780 \mathrm{~nm}, \\
\left.21.5-23.0 \mathrm{~mW} \mathrm{~cm}{ }^{-2}\right), 50 \mathrm{~mL} \\
6.5 \times 10^{-5} \mathrm{~mol} / \mathrm{L} \text { of } \mathrm{AR} 18 \\
60 \mathrm{~min}\end{array}$ & $90 \%$ & $53 \%$ for $\mathrm{Ag}_{3} \mathrm{PO}_{4}$ & [31] \\
\hline $\begin{array}{c}\mathrm{Ag}_{3} \mathrm{PO}_{4} / \mathrm{C}_{60} \\
(1 \mathrm{~g} / \mathrm{L}) \\
\end{array}$ & Precipitation $(5.0$ mg/L) & Methyl Orange (MO) & $\begin{array}{c}300 \mathrm{~W} \text { xenon lamp }(>420 \mathrm{~nm}), \\
10 \mathrm{mg} / \mathrm{L}\end{array}$ & $\mathrm{k}=0.453 \mathrm{~min}^{-1}$ & $\begin{array}{c}\mathrm{k}=0.028 \mathrm{~min}^{-1} \text { for } \\
\mathrm{Ag}_{3} \mathrm{PO}_{4}\end{array}$ & [72] \\
\hline $\begin{array}{l}\mathrm{PbMoO}_{4} / \mathrm{C}_{60} \\
(0.4 \mathrm{~g} / \mathrm{L})\end{array}$ & $\begin{array}{l}\text { Hydrothermal synthesis } \\
\qquad(0.5 \mathrm{wt} \%)\end{array}$ & RhB & $\begin{array}{c}18 \mathrm{~W} \text { low-pressure mercury } \\
\text { lamp as the UV light source, } \\
50 \mathrm{~mL} \text { of } \mathrm{RhB}\left(1 \times 10^{-5} \mathrm{M}\right) \\
2 \mathrm{~h}\end{array}$ & $99 \%$ & $37 \%$ for $\mathrm{PbMoO}_{4}$ & [50] \\
\hline $\begin{array}{l}\mathrm{Bi}_{2} \mathrm{WO}_{6} / \mathrm{C}_{60} \\
\quad(1 \mathrm{~g} / \mathrm{L})\end{array}$ & $\begin{array}{l}\text { Simple adsorption } \\
\quad(1.25 \mathrm{wt} \%)\end{array}$ & MB, RhB & $\begin{array}{c}500 \mathrm{~W} \text { xenon lamp }(>420 \mathrm{~nm}) \\
1 \times 10^{-5} \mathrm{~mol} / \mathrm{L} \mathrm{RhB} \text { or } \mathrm{MB} \\
(100 \mathrm{~mL})\end{array}$ & $\begin{array}{l}\mathrm{k}_{1}=0.0099 \mathrm{~min}^{-1} \\
\mathrm{k}_{2}=0.0454 \mathrm{~min}^{-1}\end{array}$ & $\begin{array}{l}\text { 5.0- and 1.5-times } \\
\text { than } \mathrm{Bi}_{2} \mathrm{WO}_{6}\end{array}$ & [40] \\
\hline $\begin{array}{l}\mathrm{BiOCl} / \mathrm{C}_{70} \\
(1 \mathrm{~g} / \mathrm{L})\end{array}$ & In-situ growth (1.0 wt \%) & RhB & $\begin{array}{c}500 \mathrm{~W} \text { xenon lamp (>420 nm), } \\
10 \mathrm{mg} / \mathrm{L}, 30 \mathrm{~min}\end{array}$ & $99.8 \%$ & $\begin{array}{l}49.7 \% \text { and } 66.4 \% \text { for } \\
\mathrm{BiOCl} \text { and } \mathrm{P} 25\left(\mathrm{TiO}_{2}\right)\end{array}$ & [39] \\
\hline $\mathrm{Bi}_{2} \mathrm{TiO}_{4} \mathrm{~F}_{2} / \mathrm{C}_{60}$ & $\begin{array}{l}\text { Solvothermal method } \\
\qquad(1.0 \mathrm{wt} \%)\end{array}$ & RhB & $\begin{array}{l}\text { Visible light, } 20 \mathrm{ppm} \mathrm{RhB}, \\
120 \mathrm{~min}\end{array}$ & $93 \%$ & $65 \%$ for $\mathrm{Bi}_{2} \mathrm{TiO}_{4} \mathrm{~F}_{2}$ & [73] \\
\hline $\begin{array}{l}\mathrm{CNTs} / \mathrm{BiVO}_{4}-\mathrm{C}_{60} \\
\quad(2 \mathrm{~g} / \mathrm{L})\end{array}$ & $\begin{array}{l}\text { Hydrothermal synthesis } \\
\qquad(2.5 \mathrm{wt} \%)\end{array}$ & RhB & $\begin{array}{l}300 \mathrm{~W} \text { xenon lamp }(>420 \mathrm{~nm}) \\
100 \mathrm{~mL}, 0.01 \mathrm{mmol} / \mathrm{L} \mathrm{RhB}, \\
30 \mathrm{~min}\end{array}$ & $96.1 \%$ & $74.0 \%$ for $\mathrm{BiVO}_{4}$ & [51] \\
\hline $\begin{array}{c}\mathrm{CNTs} / \mathrm{Bi}_{2} \mathrm{MoO}_{6}-\mathrm{C}_{60} \\
(2 \mathrm{~g} / \mathrm{L})\end{array}$ & $\begin{array}{l}\text { Hydrothermal synthesis } \\
\qquad(2.5 \mathrm{wt} \%)\end{array}$ & RhB & $\begin{array}{l}300 \mathrm{~W} \text { xenon lamp }(>420 \mathrm{~nm}) \\
100 \mathrm{~mL}, 0.01 \mathrm{mmol} / \mathrm{L} \mathrm{RhB}, \\
30 \mathrm{~min}\end{array}$ & $88.4 \%$ & $43.7 \%$ for $\mathrm{Bi}_{2} \mathrm{MoO}_{6}$ & [51] \\
\hline $\begin{array}{c}\mathrm{Ag}_{3} \mathrm{PO}_{4} / \mathrm{Fe}_{3} \mathrm{O}_{4} / \mathrm{C}_{60} \\
(1 \mathrm{~g} / \mathrm{L})\end{array}$ & $\begin{array}{l}\text { Hydrothermal synthesis } \\
\qquad(5.0 \mathrm{wt} \%)\end{array}$ & MB & $\begin{array}{c}400 \mathrm{~W} \text { mercury lamp }(>420 \\
\mathrm{nm}), 50 \mathrm{~mL} \text { of } \mathrm{MB}(25 \mathrm{mg} / \mathrm{L}) \\
300 \mathrm{~min}\end{array}$ & $95 \%$ & $33 \%$ for $\mathrm{Ag}_{3} \mathrm{PO}_{4}$ & [74] \\
\hline
\end{tabular}


Table 1. Cont.

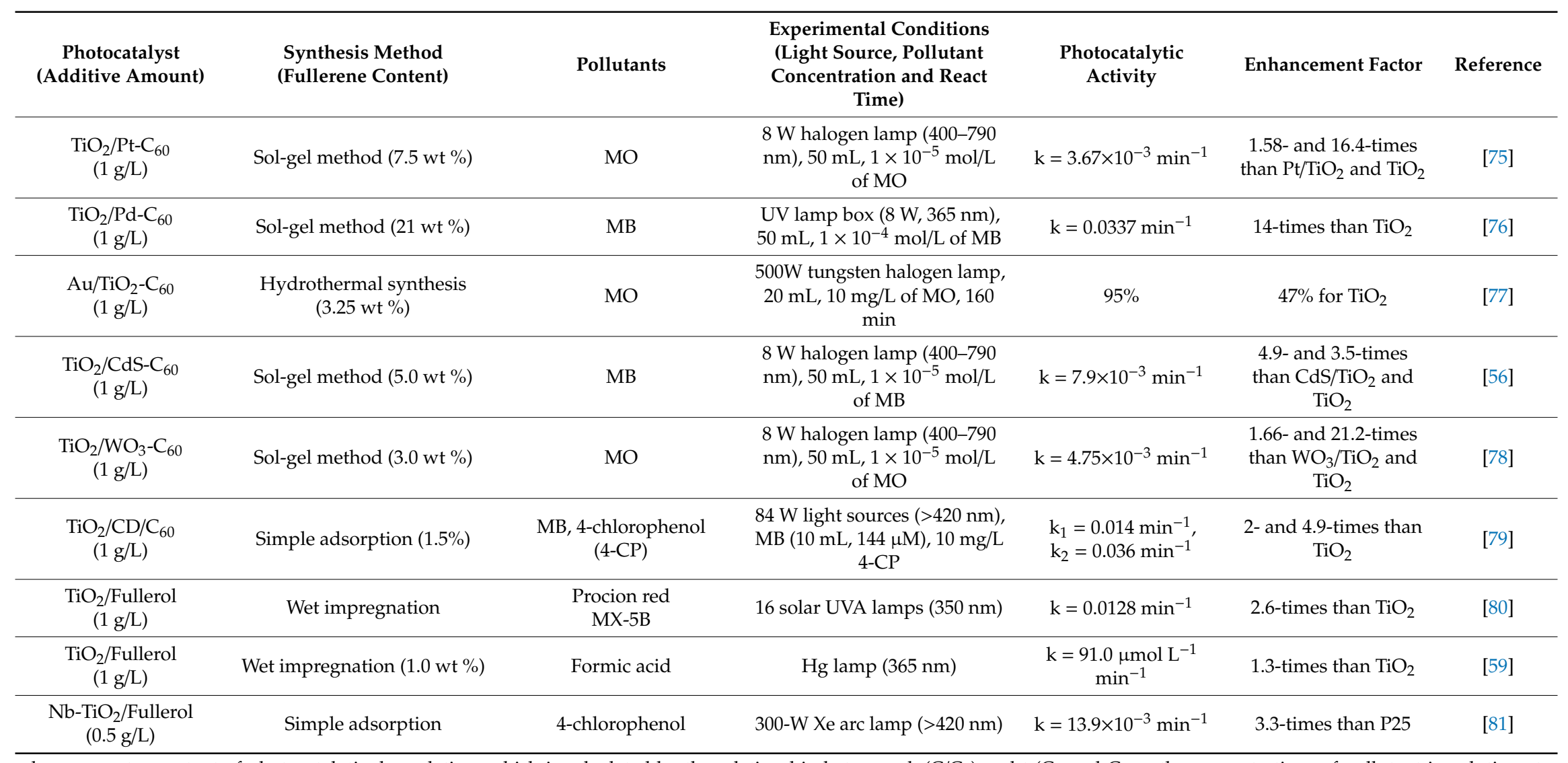

$\mathrm{k}$ means rate constant of photocatalytic degradation, which is calculated by the relationship between $-\ln \left(\mathrm{C} / \mathrm{C}_{0}\right)$ and $\mathrm{t}\left(\mathrm{C}_{0}\right.$ and $\mathrm{C}$ are the concentrations of pollutant in solution at times 0 and $t$, respectively). 
Table 2. Summary of fullerene based photocatalysts for photocatalytic $\mathrm{H}_{2}$ generation.

\begin{tabular}{|c|c|c|c|c|c|}
\hline $\begin{array}{c}\text { Photocatalyst } \\
\text { (Additive Amount) }\end{array}$ & $\begin{array}{l}\text { Synthesis Method } \\
\text { (Fullerene Content) }\end{array}$ & Experimental Conditions & $\begin{array}{c}\text { Photocatalytic Rate of } \mathbf{H}_{2} \\
\text { Generation }\end{array}$ & Enhancement Factor & Reference \\
\hline $\begin{array}{l}\mathrm{CdS} / \mathrm{C}_{60} \\
(0.5 \mathrm{~g} / \mathrm{L})\end{array}$ & $\begin{array}{c}\text { Hydrothermal } \\
\text { synthesis }(0.4 \mathrm{wt} \%)\end{array}$ & $\begin{array}{c}300 \mathrm{~W} \text { xenon lamp }(>420 \mathrm{~nm}), \\
50 \mathrm{~mL} \text { aqueous solution } \\
\text { containing } 10 \mathrm{vol} \% \text { lactic acid } \\
\text { and } 1 \mathrm{wt} \% \mathrm{Pt}\end{array}$ & $1.73 \mathrm{mmol} \mathrm{h}^{-1} \mathrm{~g}^{-1}$ & 2.3 Times of pure CdS & [43] \\
\hline $\begin{array}{c}\mathrm{WO}_{3} @ \mathrm{C}_{60} \\
(0.5 \mathrm{~g} / \mathrm{L})\end{array}$ & $\begin{array}{c}\text { Hydrothermal } \\
\text { synthesis (4 wt \%) }\end{array}$ & $\begin{array}{c}300 \mathrm{~W} \text { xenon lamp }(>420 \mathrm{~nm}) \\
\text { Triethanolamine (TEA) }\end{array}$ & $154 \mu \mathrm{mol} \mathrm{h}^{-1} \mathrm{~g}^{-1}$ & 2 times of pure $\mathrm{WO}_{3}$ & [53] \\
\hline $\begin{array}{l}\mathrm{MoS}_{2} / \mathrm{C}_{60} \\
(0.5 \mathrm{~g} / \mathrm{L})\end{array}$ & $\begin{array}{l}\text { Ball milling method } \\
(2.8 \mathrm{wt} \%)\end{array}$ & $\begin{array}{l}300 \mathrm{~W} \text { xenon lamp }(>420 \mathrm{~nm}) \\
20 \mathrm{~mL} \text { aqueous solution } \\
\text { containing } 3.5 \mathrm{mg} \text { Eosin } \mathrm{Y} \\
\text { (EY) and } 1 \mathrm{~mL} \text { TEA }\end{array}$ & $6.89 \mathrm{mmol} \mathrm{h}^{-1} \mathrm{~g}^{-1}$ & $\begin{array}{l}9.3 \text { times of ball-milled } \\
\qquad \mathrm{MoS}_{2}\end{array}$ & [54] \\
\hline $\begin{array}{l}\mathrm{g}-\mathrm{C}_{3} \mathrm{~N}_{4} / \mathrm{C}_{60} \\
\quad(1 \mathrm{~g} / \mathrm{L})\end{array}$ & $\begin{array}{l}\text { Ball milling method } \\
(12 \mathrm{wt} \%)\end{array}$ & $\begin{array}{c}300 \mathrm{~W} \text { xenon lamp }(>420 \mathrm{~nm}) \\
100 \mathrm{~mL} \text { aqueous solution } \\
\text { containing } 17.5 \mathrm{mg} \text { EY and } \\
5 \mathrm{~mL} \text { TEA }\end{array}$ & $266 \mu \mathrm{mol} \mathrm{h}^{-1} \mathrm{~g}^{-1}$ & $\begin{array}{l}4.0 \text { times higher than } \\
\text { pristine } \mathrm{C}_{3} \mathrm{~N}_{4}\end{array}$ & [55] \\
\hline $\begin{array}{l}\mathrm{Cr}_{1.3} \mathrm{Fe}_{0.7} \mathrm{O}_{3}-\mathrm{C}_{60} \\
\quad(5 \mathrm{mg} / 78 \mathrm{~mL})\end{array}$ & $\begin{array}{c}\text { Simple adsorption } \\
(3 \%)\end{array}$ & $\begin{array}{c}300 \mathrm{~W} \text { xenon lamp }(>420 \mathrm{~nm}) \\
78 \mathrm{~mL} 10 \mathrm{vol} \% \text { TEA aqueous } \\
\text { solution }\end{array}$ & $220.5 \mu \mathrm{mol} \mathrm{h}^{-1} \mathrm{~g}^{-1}$ & 2 times of the $\mathrm{Cr}_{1.3} \mathrm{Fe}_{0.7} \mathrm{O}_{3}$ & [82] \\
\hline $\begin{array}{c}\mathrm{Fe}_{2} \mathrm{O}_{3} / \mathrm{C}_{60} \\
(5 \mathrm{mg} / 78 \mathrm{~mL})\end{array}$ & $\begin{array}{l}\text { Simple adsorption } \\
\quad(0.5 \sim 1 \mathrm{wt} \%)\end{array}$ & $\begin{array}{c}300 \mathrm{~W} \text { xenon lamp }(>420 \mathrm{~nm}) \\
78 \mathrm{~mL} 10 \mathrm{vol} \% \text { TEA aqueous } \\
\text { solution }\end{array}$ & $\begin{array}{l}\beta-\mathrm{Fe}_{2} \mathrm{O}_{3} / \mathrm{C}_{60}: 1665 \mu \mathrm{mol} \mathrm{h}^{-1} \mathrm{~g}^{-1} \\
\alpha-\mathrm{Fe}_{2} \mathrm{O}_{3} / \mathrm{C}_{60}: 202.9 \mu \mathrm{mol} \mathrm{h}^{-1} \mathrm{~g}^{-1} \\
\gamma-\mathrm{Fe}_{2} \mathrm{O}_{3} / \mathrm{C}_{60}: 169.4 \mu \mathrm{mol} \mathrm{h}^{-1} \mathrm{~g}^{-1}\end{array}$ & $\begin{array}{c}\beta-\mathrm{Fe}_{2} \mathrm{O}_{3}: \\
169.4 \mu \mathrm{mol} \mathrm{h}^{-1} \mathrm{~g}^{-1} \\
\alpha-\mathrm{Fe}_{2} \mathrm{O}_{3}: \\
80.6 \mu \mathrm{mol} \mathrm{h}^{-1} \mathrm{~g}^{-1} \\
\gamma-\mathrm{Fe}_{2} \mathrm{O}_{3}: \\
252 \mu \mathrm{mol} \mathrm{h}^{-1} \mathrm{~g}^{-1} ; \\
\mathrm{C}_{3} \mathrm{~N}_{4}: 82.7 \mu \mathrm{mol} \mathrm{h}^{-1} \mathrm{~g}^{-1}\end{array}$ & [83] \\
\hline $\begin{array}{l}\mathrm{CdS} / \mathrm{TiO}_{2}-\mathrm{C}_{60} \\
(50 \mathrm{mg} / 80 \mathrm{~mL})\end{array}$ & $\begin{array}{l}\text { An ion-exchanged } \\
\text { method }(0.5 \mathrm{wt} \%)\end{array}$ & $\begin{array}{c}\text { Low power UV-LEDs } \\
(420 \mathrm{~nm}), 80 \mathrm{~mL} \text { solution } \\
\left(0.25 \mathrm{M} \mathrm{Na}_{2} \mathrm{~S}, 0.25 \mathrm{M} \mathrm{Na}_{2} \mathrm{SO}_{3}\right)\end{array}$ & $120.6 \mu \mathrm{mol} \mathrm{h}^{-1} \mathrm{~g}^{-1}$ & 8.5 times of $\mathrm{CdS} / \mathrm{TiO}_{2}$ & [84] \\
\hline $\begin{array}{c}\mathrm{TiO}_{2} / \mathrm{C}_{60}-\mathrm{d}-\mathrm{CNTs} \\
(1 \mathrm{~g} / \mathrm{L})\end{array}$ & $\begin{array}{c}\text { Hydrothermal } \\
\text { synthesis (5 wt \%) }\end{array}$ & $\begin{array}{c}300 \mathrm{~W} \text { xenon lamp }(>420 \mathrm{~nm}) \\
100 \mathrm{~mL} 10 \text { vol } \% \text { TEA aqueous } \\
\text { solution }\end{array}$ & $651 \mu \mathrm{mol} \mathrm{h}{ }^{-1} \mathrm{~g}^{-1}$ & $\begin{array}{c}208 \mu \mathrm{mol} \mathrm{h}{ }^{-1} \mathrm{~g}^{-1} \text { for pure } \\
\mathrm{TiO}_{2}\end{array}$ & [85] \\
\hline
\end{tabular}


Table 2. Cont.

\begin{tabular}{|c|c|c|c|c|c|}
\hline $\begin{array}{c}\text { Photocatalyst } \\
\text { (Additive Amount) }\end{array}$ & $\begin{array}{l}\text { Synthesis Method } \\
\text { (Fullerene Content) }\end{array}$ & Experimental Conditions & $\begin{array}{c}\text { Photocatalytic Rate of } \mathbf{H}_{2} \\
\text { Generation }\end{array}$ & Enhancement Factor & Reference \\
\hline $\begin{array}{c}\text { g- } C_{3} \mathrm{~N}_{4} / \text { graphene } / \mathrm{C}_{60} \\
(2 \mathrm{~g} / \mathrm{L})\end{array}$ & Wet impregnation & $\begin{array}{c}\text { Light-emitting diode } \\
(>420 \mathrm{~nm}), 50 \mathrm{~mL} \text { solution } \\
\text { containing } 1 \mathrm{wt} \% \text { o Pt and } \\
10 \mathrm{vol} \% \text { TEA }\end{array}$ & $545 \mu \mathrm{mol} \mathrm{h}^{-1} \mathrm{~g}^{-1}$ & $\begin{array}{c}50.8 \text { and } 4.24 \text { times of } \\
\text { graphene/g- } \mathrm{C}_{3} \mathrm{~N}_{4} \text { and } \\
\mathrm{C}_{60} / \mathrm{g}-\mathrm{C}_{3} \mathrm{~N}_{4}\end{array}$ & [19] \\
\hline $\begin{array}{l}\text { (2TPABTz)-metal } \\
\text { complex } / \mathrm{C}_{60}\end{array}$ & $\begin{array}{l}\text { Simple adsorption } \\
\quad(2 \mathrm{wt} \%)\end{array}$ & $\begin{array}{c}300 \mathrm{~W} \text { xenon lamp }(>420 \mathrm{~nm}) \\
\text { an aqueous lactic acid (LA) }\end{array}$ & $\begin{array}{c}\text { 2TPABTz-Cu/C } \mathrm{C}_{60}: \\
4.05 \mathrm{mmol} \mathrm{h} \mathrm{g}^{-1} \\
\text { 2TPABTz-Co/C } \mathrm{C}_{60}: \\
3.77 \mathrm{mmol} \mathrm{h}^{-1} \mathrm{~g}^{-1} \\
\text { 2TPABTz-Ru/C } \\
6.12 \mathrm{mmol} \mathrm{h}^{-1} \mathrm{~g}^{-1}\end{array}$ & $\begin{array}{c}\text { 2TPABTz-Cu: } \\
4.05 \mathrm{mmol} \mathrm{h}^{-1} \mathrm{~g}^{-1} \\
\text { 2TPABTz-Co: } \\
\text { 3.77 } \mathrm{mmol} \mathrm{h}^{-1} \mathrm{~g}^{-1} \\
\text { 2TPABTz-Ru: } \\
\text { 6.12 } \mathrm{mmol} \mathrm{h}^{-1} \mathrm{~g}^{-1} \\
\mathrm{TiO}_{2}\left(\mathrm{P}^{25}\right): \\
0.072 \mathrm{mmol} \mathrm{h}^{-1} \mathrm{~g}^{-1}\end{array}$ & [86] \\
\hline $\begin{array}{c}\mathrm{WO}_{3} / \mathrm{C}_{60} @ \mathrm{Ni}_{3} \mathrm{~B} / \mathrm{Ni}(\mathrm{OH})_{2} \\
2 \mathrm{~g} / \mathrm{L}\end{array}$ & $\begin{array}{l}\text { Photo-deposition } \\
\text { technique }\end{array}$ & $\begin{array}{c}500 \mathrm{~W} \text { xenon lamp }(>420 \mathrm{~nm}) \\
100 \mathrm{~mL} 10 \text { vol } \% \text { TEA aqueous } \\
\text { solution }\end{array}$ & $1.578 \mathrm{mmol} \mathrm{h}^{-1} \mathrm{~g}^{-1}$ & $\begin{array}{l}9.6 \text { times of pure } \\
\text { photocatalyst }\end{array}$ & [87] \\
\hline
\end{tabular}


In addition to UV-light-driven photocatalytic activity, $\mathrm{TiO}_{2} / \mathrm{C}_{60}$ nanocomposites also exhibit superior photocatalytic capacity under visible light irradiation. In this visible-light-driven photocatalytic system, the introduced $\mathrm{C}_{60}$ could typically enhance the photocatalytic activity in two ways at the same time: one is to increase the visible light adsorption, the other is to prolong the lifetimes of photoinduced carriers for participating redox reaction. For example, an investigation was conducted into the visible-light-induce photocatalytic activity of $\mathrm{TiO}_{2} / \mathrm{C}_{60}$ towards $\mathrm{MB}$ degradation [88]. In this study, two crystals of $\mathrm{TiO}_{2}$ (anatase and rutile) were coupled with $\mathrm{C}_{60}$ to assemble photocatalysts and the rutile- $\mathrm{C}_{60}$ exhibited significantly superior efficiency than pristine rutile under visible illumination. Grandcolas, et al. [89] synthesized $\mathrm{C}_{60}$ modified $\mathrm{TiO}_{2}$ nanotubes via a simple impregnation method using ethanol and toluene as co-solvents, and the as-prepared sample exhibited superior efficiency in photocatalytic isopropanol degradation under visible light irradiation. More recently, a polycarboxylic acid functionalized fullerene $\left(\mathrm{C}_{60}-(\mathrm{COOH})_{\mathrm{n}}\right)$ was coupled with $\mathrm{TiO}_{2}$ to obtain a novel photocatalyst $\mathrm{TiO}_{2} / \mathrm{C}_{60}$ nanocomposite via ultrasonication-evaporation method for the first time [68]. For the as-prepared photocatalysts, the introduction of $\mathrm{C}_{60}$ obviously decreased the aggregation of pure $\mathrm{TiO}_{2}$ nanocomposites (Figure $2 \mathrm{a}, \mathrm{b}$ ), and the $\mathrm{C}_{60}$ particles were well-dispersed and closely contacted onto the surface of $\mathrm{TiO}_{2}$ (Figure 2c). Compared with pure $\mathrm{TiO}_{2}$, the $1 \mathrm{wt} \% \mathrm{TiO}_{2} / \mathrm{C}_{60}$ exhibited stronger both UV and visible light absorption, resulting in improving the utilization of light energy (Figure 2d). In order to trace oxidative species involved in the photocatalytic reaction, in situ radical trapping experiments were made, wherein EDTA was used for trapping holes and 1,4-benzoquinone (BQ) was a scavenger for $\bullet \mathrm{O}_{2}{ }^{-}$. In the presence of EDTA, the photocatalytic degradation efficiency to $\mathrm{RhB}$ was dramatically retarded, and a similar trend was also observed with $B Q$ addition (Figure 2e). These results meant that the photoinduced $\mathrm{h}^{+}$and $\bullet \mathrm{O}_{2}{ }^{-}$were involved in the photocatalytic reaction. Under visible light illumination for $150 \mathrm{~min}, 1 \mathrm{wt} \% \mathrm{TiO}_{2} / \mathrm{C}_{60}$ nanocomposite showed $95 \%$ degradation efficiency to $\mathrm{RhB}$, which was significantly higher than pristine $\mathrm{TiO}_{2}$ (Figure 2f). To further check the stability of the $\mathrm{TiO}_{2} / \mathrm{C}_{60}$ photocatalyst, the recovered composite was used for repeatedly photocatalytic degradation experiment towards RhB. After five repeated experiments under visible light irradiation for $150 \mathrm{~min}$, the degradation efficiency decreased from $95 \%$ to around $80 \%$. There is no doubt that the long-term stability of photocatalysts is particularly vital to practical application. Therefore, future work could focus on the synthesis method of $\mathrm{TiO}_{2}$ to improve the stability of $\mathrm{TiO}_{2} / \mathrm{C}_{60}$ photocatalysts. For example, Bastakoti, et al. [90] reported a high-efficiency method to fabricate more stable mesoporous metal oxides (including $\mathrm{TiO}_{2}, \mathrm{Ta}_{2} \mathrm{O}_{5}$ and $\mathrm{Nb}_{2} \mathrm{O}_{5}$ ).

Compared to $\mathrm{TiO}_{2}, \mathrm{C}_{70}$ is a close-shell configuration consisting of 35 bonding molecular orbitals with $70 \mathrm{p}$-electrons [91]. Similar to $\mathrm{C}_{60}, \mathrm{C}_{70}$ has higher electron acceptability and higher efficiency of light harvesting over $\mathrm{TiO}_{2}[92,93]$. Thus, $\mathrm{C}_{70}$ is a promising alternative to boost the photocatalytic efficiency of $\mathrm{TiO}_{2}$. Cho, et al. [94] fabricated both $\mathrm{TiO}_{2} / \mathrm{C}_{60}$ and $\mathrm{TiO}_{2} / \mathrm{C}_{70}$ nanowire to estimate their photocatalytic activity. In this study, $\mathrm{TiO}_{2} / \mathrm{C}_{70}$ showed a significantly stronger absorbance within $400 \sim 650 \mathrm{~nm}$ and a lower photoluminescence spectra (PL) than $\mathrm{TiO}_{2} / \mathrm{C}_{60}$. This means the $\mathrm{C}_{70}$ displayed better efficiency in boosting visible light absorption and inhibiting recombination of hole-electron pairs than $\mathrm{C}_{60}$. Accordingly, the $\mathrm{TiO}_{2} / \mathrm{C}_{70}$ nanowire displayed higher photocatalytic activity for $\mathrm{MB}$ degradation than $\mathrm{TiO}_{2} / \mathrm{C}_{60}$ in the visible light irradiation. Furthermore, Wang, Liu, Dai, Cai, Chen, Yang and Huang [69] assembled $\mathrm{TiO}_{2}-\mathrm{C}_{70}$ hybrids using acid-treated $\mathrm{C}_{70}, \mathrm{Ti}\left(\mathrm{SO}_{4}\right)_{2}$ and cetyltrimethylammonium bromide (CTAB) by a hydrothermal method. It was proven that the $8.5 \mathrm{wt} \% \mathrm{TiO}_{2}-\mathrm{C}_{70}$ showed the best photodegradation efficiency to sulfathiazole under visible light, which was 4.2 times that of $\mathrm{TiO}_{2}+\mathrm{C}_{70}$ mixture and 1.6 times that of the corresponding $\mathrm{TiO}_{2}-\mathrm{C}_{60}$ nanocomposite, respectively. The SEM and TEM images of $18 \mathrm{wt} \% \mathrm{TiO}_{2}-\mathrm{C}_{70}$ nanocomposite are shown in Figure $3 \mathrm{a}, \mathrm{b}$. After $\mathrm{C}_{70}$ introduction, the surface of $\mathrm{TiO}_{2}-\mathrm{C}_{70}$ nanocomposites were uneven, which could increase the BET of the as-prepared samples. The $\mathrm{C}_{70}$ particles were well-dispersed onto the outer boundary of $\mathrm{TiO}_{2}$ composites, and it was estimated that a monolayer of $\mathrm{C}_{70}$ was covered onto the surface of $\mathrm{TiO}_{2}$. Additionally, the $\mathrm{TiO}_{2}-\mathrm{C}_{70}$ exhibited better light absorption and higher separation efficiency of hole-electron pairs than those of $\mathrm{TiO}_{2}-\mathrm{C}_{60}$ and pure $\mathrm{TiO}_{2}$ (Figure $\left.3 c, d\right)$. It is important to highlight that novel mechanisms of $\mathrm{TiO}_{2} /$ fullerene were proposed for photocatalytic pollutant 
degradation [69]. From two aspects, UV light and visible light irradiation, the mechanisms are described as follows. Under UV light illumination, electrons are excited from $\mathrm{VB}$ to $\mathrm{CB}$ of $\mathrm{TiO}_{2}$, leaving holes in the VB. Then the $\mathrm{CB}$ electrons of $\mathrm{TiO}_{2}$ could rapidly transfer to $\mathrm{C}_{70}$, because the $\mathrm{CB}$ potential of $\mathrm{TiO}_{2}$ ( $0.5 \mathrm{~V}$ vs. NHE) is more negative relative to $\mathrm{C}_{70} / \mathrm{C}_{70}{ }^{-}(0.2 \mathrm{~V}$ vs. NHE). In the meantime, the ground-state $\mathrm{C}_{70}$ is excited to a transient-state ${ }^{1} \mathrm{C}_{70}{ }^{*}$, then undergoes rapid intersystem crossing (ISC) to a lower lying triplet state ${ }^{3} \mathrm{C}_{70}{ }^{*}$. In this system, excited electrons can be injected into the three-states transform procedure of $\mathrm{C}_{70}$, resulting in suppression of their falling back to the $\mathrm{VB}$ of $\mathrm{TiO}_{2}$. Hence, this process effectively inhibits the recombination of photoinduced hole-electron pairs, so as to elevate the photocatalytic activity of $\mathrm{TiO}_{2} / \mathrm{C}_{70}$ nanocomposite (Figure 3e). On the other hand, a viewpoint of mid-gap band was proposed for $\mathrm{TiO}_{2} / \mathrm{C}_{70}$ with respect to the visible-light-driven photocatalytic mechanism. It was pointed out that the mid-gap band came into being between $\mathrm{TiO}_{2}$ and $\mathrm{C}_{70}$ ascribing to the strong chemical boning of these two materials. The electron transfer route was obviously distinct from those $\mathrm{TiO}_{2} /$ fullerene photocatalysts in previous studies. Namely, visible light excites electrons from the $\mathrm{VB}$ of $\mathrm{TiO}_{2}$ to the mid-gap band and then from the mid-band to the $\mathrm{CB}$ of $\mathrm{TiO}_{2}$, leaving holes in the $\mathrm{VB}$ (Figure 3e). This procedure significantly prolongs the lifetime of the photoinduced carriers and facilitates the separation of hole-electron pairs for participating in photocatalytic reaction. Accordingly, the effectively separated holes and electrons participate in generation of reactive radical species. The $\mathrm{e}^{-}$could react with dissolved $\mathrm{O}_{2}$ to produce $\bullet \mathrm{O}_{2}{ }^{-}$ and $\mathrm{h}^{+}$react with $\mathrm{H}_{2} \mathrm{O}$ to produce $\bullet \mathrm{OH}$, then these radical species cause the degradation of sulfathiazole. To research the stability of $\mathrm{TiO}_{2} / \mathrm{C}_{70}$ nanocomposite, the recycled sample was dried for subsequently repeated experiments. After 5 runs (totally $15 \mathrm{~h}$ visible light illumination), the degradation efficiency to sulfathiazole over $\mathrm{TiO}_{2} / \mathrm{C}_{70}$ slightly declined, remaining over $90 \%$. This evidenced that the aforementioned hydrothermal method was effective in building stable $\mathrm{TiO}_{2} /$ fullerene photocatalysts.

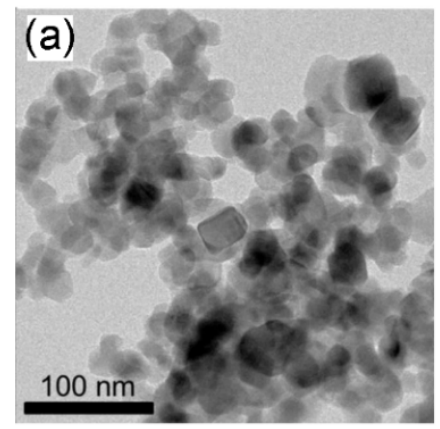

(d)

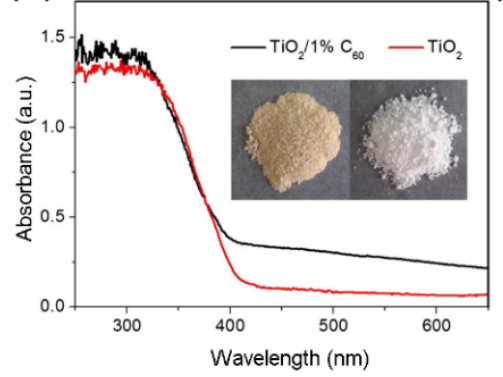

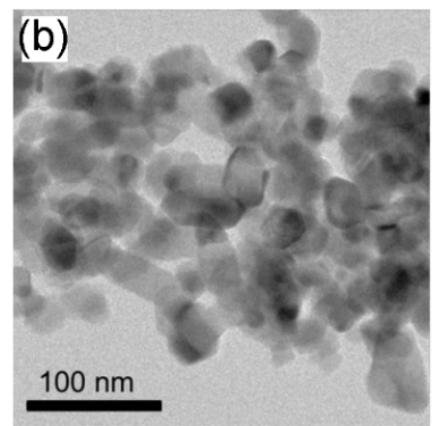

(e)

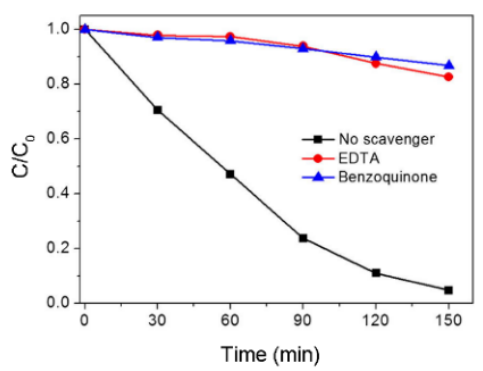

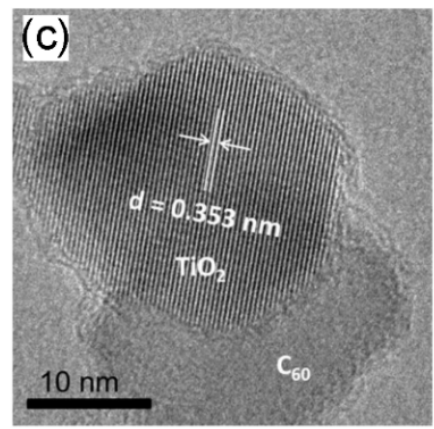

(f)

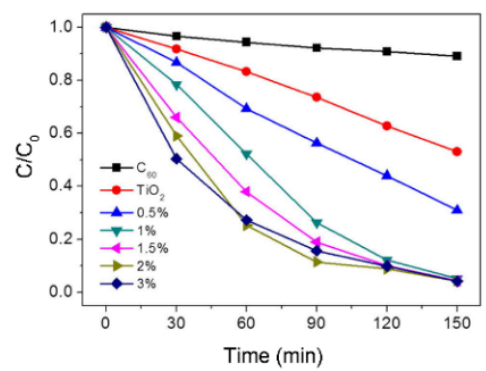

Figure 2. TEM images of $\mathrm{TiO}_{2}(\mathbf{a})$ and $\mathrm{TiO}_{2} / \mathrm{C}_{60}$ (b). (c) HR-TEM image of $\mathrm{TiO}_{2} / \mathrm{C}_{60}$. (d) Diffuse reflectance spectroscopy (DRS) of $\mathrm{TiO}_{2} / \mathrm{C}_{60}$ and pure $\mathrm{TiO}_{2}$. (e) Free radical capture experiment within photocatalytic degradation of $\mathrm{RhB}$. (f) Photocatalytic degradation towards $\mathrm{RhB}$ over the $\mathrm{TiO}_{2} / \mathrm{fullerene}$ nanocomposite under the visible light irradiation. Reproduced with permission from Reference [68]. Copyright 2016, Elsevier.

Oh and Ko [95] fabricated Pt-fullerene/ $/ \mathrm{TiO}_{2}$ nanocomposites via in-situ growth method using Pt-treated oxidized fullerene and TNB. Firstly, fullerene was oxidized by MCPBA and treated through ion exchange using potassium hexachloroplatinate (IV) $\left(\mathrm{K}_{2}\left[\mathrm{PtCl}_{6}\right]\right)$, wherein Pt-treated oxidized 
fullerene was obtained. Then, Pt-fullerene was added into TNB solution (titanium source) for fabricating Pt-fullerene/ $/ \mathrm{TiO}_{2}$ nanocomposite via a sol-gel method under mild condition $\left(50{ }^{\circ} \mathrm{C}\right)$. The as-prepared sample exhibited elevated performance under UV light and the order of photocatalytic efficiency for $\mathrm{MB}$ degradation was: Pt-fullerene/ $/ \mathrm{TiO}_{2}>$ fullerene $/ \mathrm{TiO}_{2}>$ pristine $\mathrm{TiO}{ }_{2}$, due to the synergetic effects of $\mathrm{Pt}$, oxidized-fullerene and $\mathrm{TiO}_{2}$. In this study, it was proposed that Pt-fullerene was homogeneously covered with $\mathrm{TiO}_{2}$ particles, wherein $\mathrm{TiO}_{2}$ would be mounted in a 3-dimensional matrix. It was concluded that three factors contributed to the superior photocatalytic activity of Pt-fullerene/ $\mathrm{TiO}_{2}$, including photocatalytic reaction of the supported $\mathrm{TiO}_{2}$, decomposition of the organo-metallic reaction by the Pt compound and energy transfer effects of fullerene. Through the same method, a number of metal-treated fullerene/ $\mathrm{TiO}_{2}$ composites were prepared for photocatalytic application as well, such as $\mathrm{Fe}-\mathrm{C}_{60} / \mathrm{TiO}_{2}, \mathrm{~V}-\mathrm{C}_{60} / \mathrm{TiO}_{2}$ and $\mathrm{Pd}-\mathrm{C}_{60} / \mathrm{TiO}_{2}$ [96,97]. For instance, Meng, Zhang, Zhu, Park, Ghosh, Choi and Oh [76] fabricated M-fullerene/TiO 2 (M representing Pt, Y or Pd) composites to compare their photocatalytic efficiency. Among these samples, the Pd-fullerene/TiO 2 showed the best photocatalytic activity for MB decomposition under UV light, due to its better dispersion and larger BET surface over the Pt-fullerene/ $\mathrm{TiO}_{2}$ and Y-fullerene/ $\mathrm{TiO}$. Further results indicated that the synergistic effects between $\mathrm{Pd}$ and fullerene improves the photocatalytic activity of $\mathrm{TiO}_{2}$, including enhancement of light adsorption by fullerene and $\mathrm{Pd}$ as the final electron-acceptor. More recently, Islam, Hangkun, Ting, Zubia, Goos, Bernal, Botez, Narayan, Chan and Noveron [77] prepared AuNPs- $\mathrm{TiO}_{2}-\mathrm{C}_{60}$ composites, wherein the introduction of $\mathrm{C}_{60}$ significantly boosts the photoactivity and photostability of AuNPs- $\mathrm{TiO}_{2}$. It was reported that $\mathrm{C}_{60}$ played threefold roles in the preparation of AuNPs- $\mathrm{TiO}_{2}-\mathrm{C}_{60}$. The introduction of $\mathrm{C}_{60}$ decreased the size of AuNPs $(5 \mathrm{~nm})$ and effectively prevented its agglomeration on the surface of $\mathrm{TiO}_{2}$, as well as linked $\mathrm{AuNPs}$ to $\mathrm{TiO}_{2}$ surface without any functionalization. The AuNPs- $\mathrm{TiO}_{2}-\mathrm{C}_{60}$ had a broader light adsorption region over pristine $\mathrm{TiO}_{2}$ and AuNPs- $\mathrm{TiO}_{2}$ nanocomposites, ranging from 500 to $650 \mathrm{~nm}$. The $4.76 \%$ optimal AuNPs-TiO $2-\mathrm{C}_{60}$ sample showed 95\% photodegradation efficiency towards $\mathrm{MO}$ after visible light irradiation for $160 \mathrm{~min}$, which was 2 times higher than pristine $\mathrm{TiO}_{2}$.

Meng and his co-workers assembled a series of semiconductor/fullerene/ $/ \mathrm{TiO}_{2}$ ternary photocatalysts via sol-gel method, such as $\mathrm{TiO}_{2} / \mathrm{CdS} / \mathrm{C}_{60}, \mathrm{TiO}_{2} / \mathrm{CdSe} / \mathrm{C}_{60}$ and $\mathrm{TiO}_{2} / \mathrm{WO}_{3} / \mathrm{C}_{60}$ nanocomposite $[56,78,98]$. For example, the $\mathrm{TiO}_{2} / \mathrm{CdS} / \mathrm{C}_{60}$ photocatalyst exhibited superior efficiency in photocatalytic pollution degradation and the $\mathrm{MO}$ degradation rate $(\mathrm{K})$ of these as-formed nanocomposites was in an order: $\mathrm{TiO}_{2} / \mathrm{CdS} / \mathrm{C}_{60}>\mathrm{TiO}_{2} / \mathrm{C}_{60}>\mathrm{TiO}_{2}>\mathrm{TiO}_{2} / \mathrm{CdS}$. In addition, Lian, $\mathrm{Xu}$, Wang, Zhang, Xiao, $\mathrm{Li}$ and $\mathrm{Li}$ [84] successfully fabricated $\mathrm{C}_{60}$ decorated $\mathrm{TiO}_{2} / \mathrm{CdS}$ mesoporous photocatalyst via an evaporation combined with ion-exchanged method. It is noteworthy that the BET of the $\mathrm{TiO}_{2} / \mathrm{CdS} / \mathrm{C}_{60}$ photocatalyst was actually lower than that of the $\mathrm{TiO}_{2} / \mathrm{CdS}$ composite, which resulted from the fact that the $\mathrm{C}_{60}$ was inset into the pore of this mesoporous composite. Compared with $\mathrm{CdS} / \mathrm{TiO}_{2}$, the $\mathrm{TiO}_{2} / \mathrm{CdS} / \mathrm{C}_{60}$ presented stronger visible light adsorption, lower recombination of photogenerated hole-electron pairs and higher photocurrent density, thus resulting in highly effectively photocatalytic ability for $\mathrm{H}_{2}$ production (Figure $4 \mathrm{a}-\mathrm{c}$ ). In $\mathrm{Na}_{2} \mathrm{~S}-\mathrm{Na}_{2} \mathrm{SO}_{3}$ reaction solution, the $\mathrm{H}_{2}$ generation rate of the optimal $0.5 \mathrm{wt} \% \mathrm{TiO}_{2} / \mathrm{CdS} / \mathrm{C}_{60}$ photocatalyst was $6.03 \mu \mathrm{mol} \mathrm{h}^{-1} \mathrm{~g}^{-1}$ with $2.0 \%$ quantum efficiency (QE) under visible light, which was obviously higher than the rate of $\mathrm{TiO}_{2} / \mathrm{CdS}$ $\left(0.71 \mu \mathrm{mol} \mathrm{h}^{-1} \mathrm{~g}^{-1}\right)$. As concluded in this study, $\mathrm{C}_{60}$ could enhance the light adsorption and facilitate the separation of photogenerated hole-electron pairs, as well as serve as $\mathrm{H}_{2}$ generation site for adsorbing and reducing $\mathrm{H}^{+}$ions. The electron transfer route and reaction mechanism are presented in Figure $4 \mathrm{~d}$. Under visible light illumination, electrons in the VB of CdS are excited into the CB firstly. Then the excited electrons in the $\mathrm{CB}$ of $\mathrm{CdS}$ rapidly transfer into the $\mathrm{CB}$ of $\mathrm{TiO}_{2}$, because the conduction band potential of the former is more negative than that of the later. Finally, the electrons in the $\mathrm{CB}$ of $\mathrm{TiO}_{2}$ transfer to $\mathrm{C}_{60}$, which provide reaction sites for reducing $\mathrm{H}^{+}$to $\mathrm{H}_{2}$. Meanwhile, the leaving holes in the VB of the CdS are consumed by $\mathrm{S}^{2-}$ and $\mathrm{SO}_{3}{ }^{2-}$ to facilitate $\mathrm{H}_{2}$ generation efficiency. Moreover, Chai, Peng, Zhang, Mao, Li and Zhang [85] developed a $\mathrm{TiO}_{2}-\mathrm{C}_{60}-\mathrm{dCNTs}$ photocatalyst, which was reported 
to enhance the photocatalytic $\mathrm{H}_{2}$ production under UV light illumination. At a $5 \mathrm{wt} \%$ loading amount of $\mathrm{C}_{60}$, it exhibited the highest $\mathrm{H}_{2}$ production rate of $651 \mu \mathrm{mol} \mathrm{h}{ }^{-1}$, which is 2.9 times that of bare $\mathrm{TiO}_{2}$.
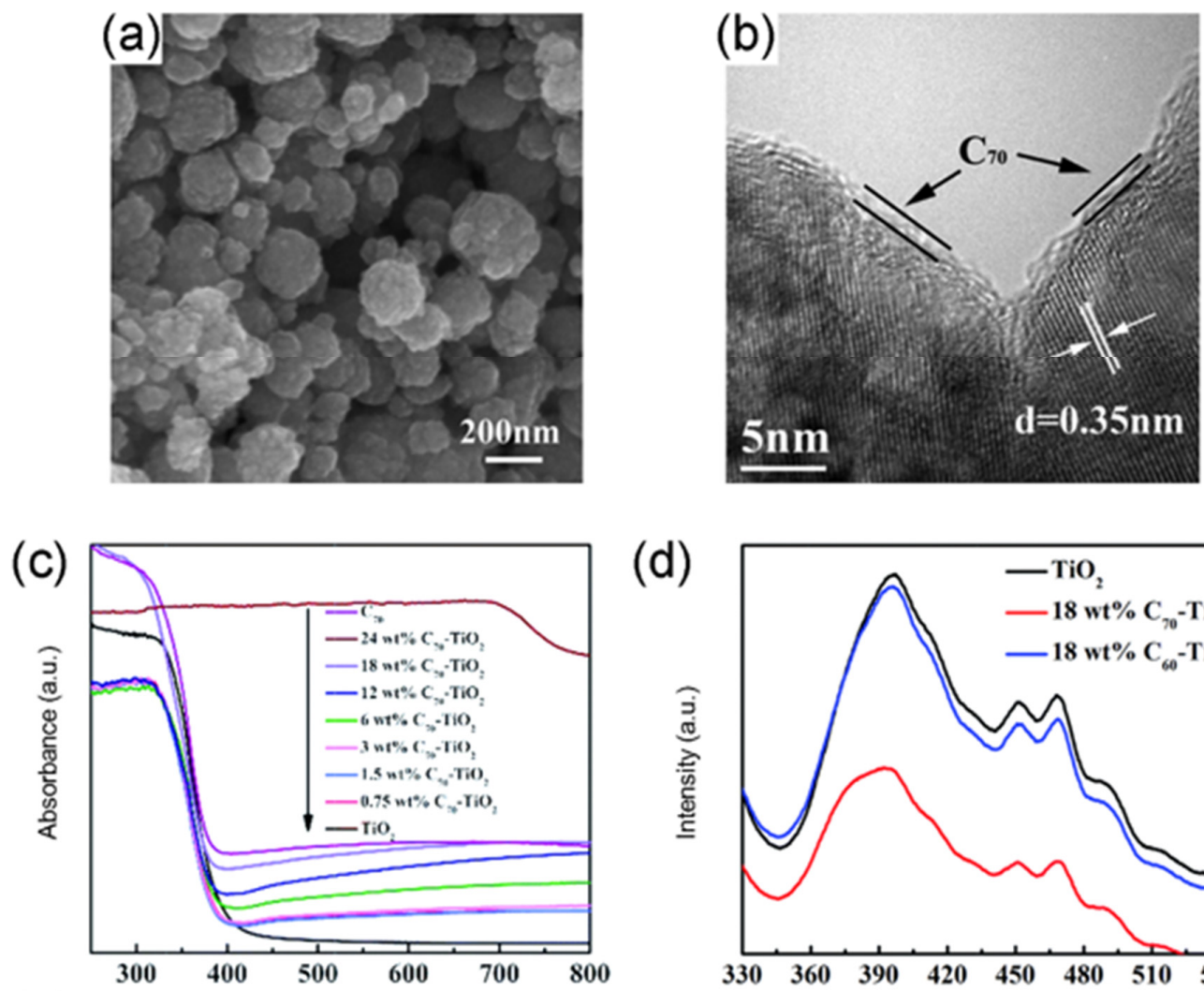

(e)
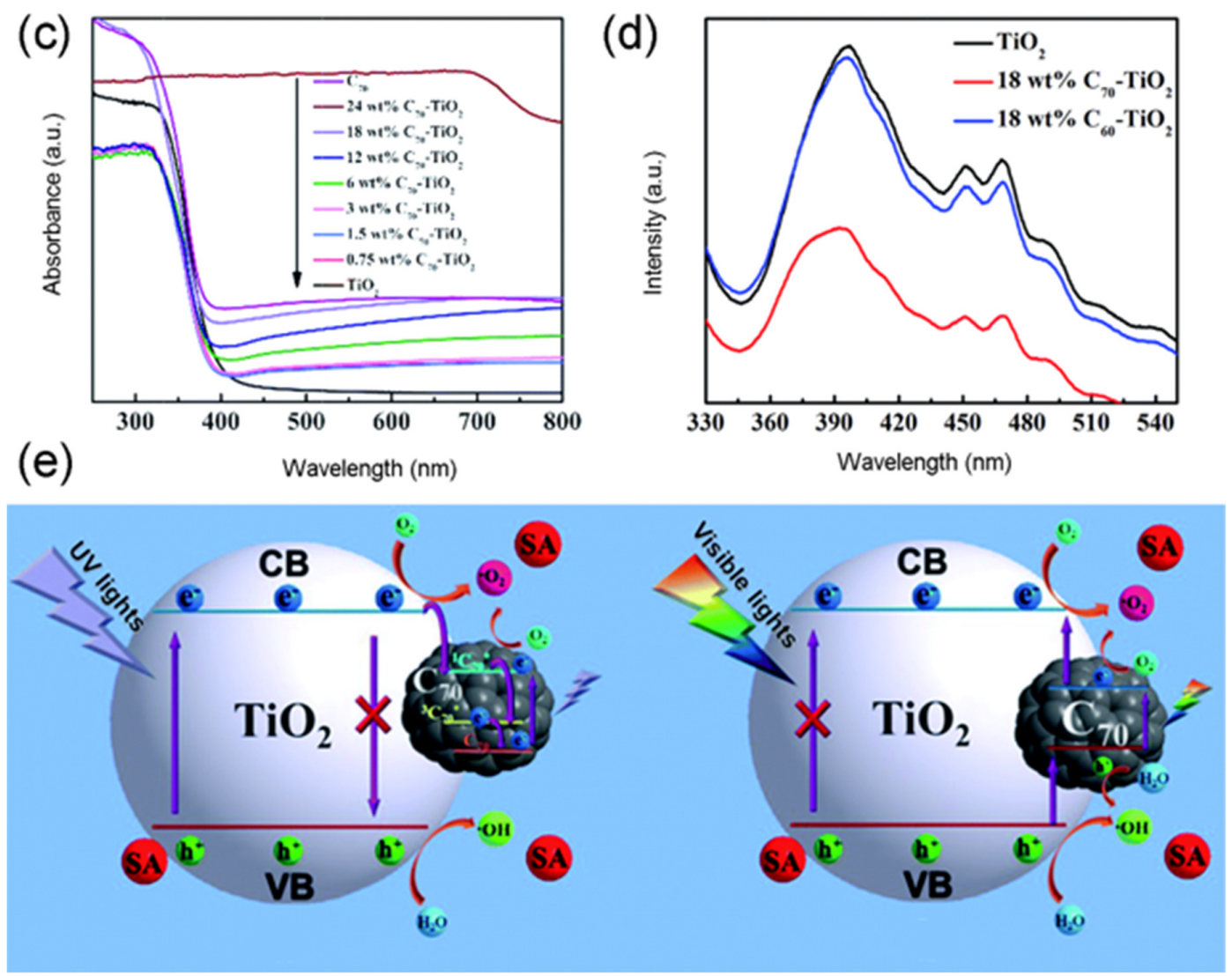

Figure 3. SEM (a) and TEM (b) images of $18 \mathrm{wt} \% \mathrm{C}_{70}-\mathrm{TiO}_{2}$. (c) $\mathrm{UV}-\mathrm{Vis}$ DRS of the $\mathrm{C}_{70}-\mathrm{TiO}_{2}$ and pure $\mathrm{TiO}_{2}$. (d) Comparison of PL spectra over $\mathrm{C}_{70}-\mathrm{TiO}_{2}, \mathrm{C}_{60}-\mathrm{TiO}_{2}$ and $\mathrm{TiO}_{2}$. (e) Photocatalytic mechanisms of $\mathrm{C}_{70}-\mathrm{TiO}_{2}$ under UV and visible light illumination. Reproduced with permission from Reference [69]. Copyright 2015, RCS. 
(a)

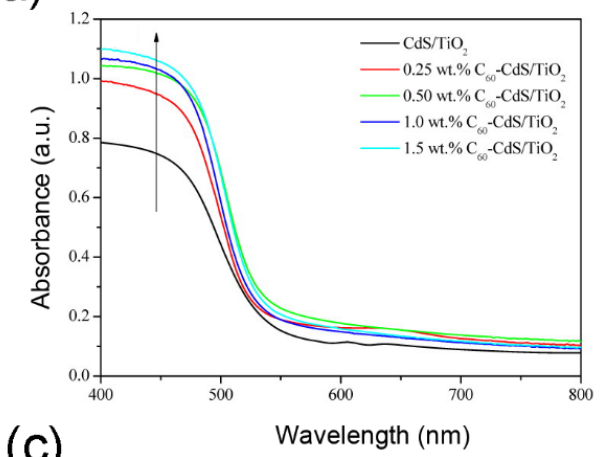

(c)

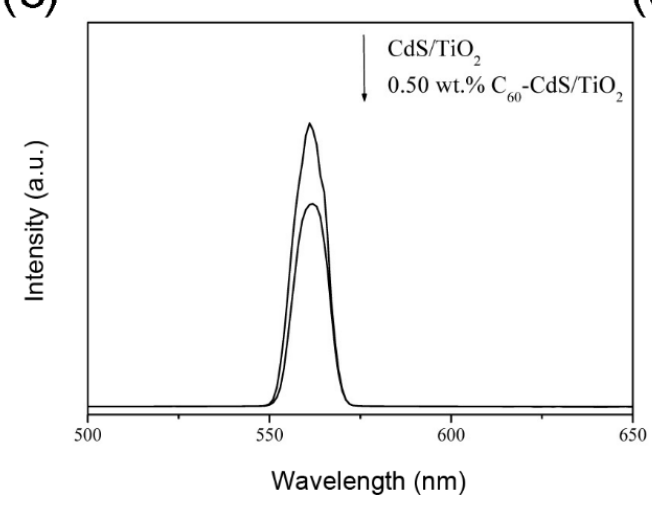

(b)

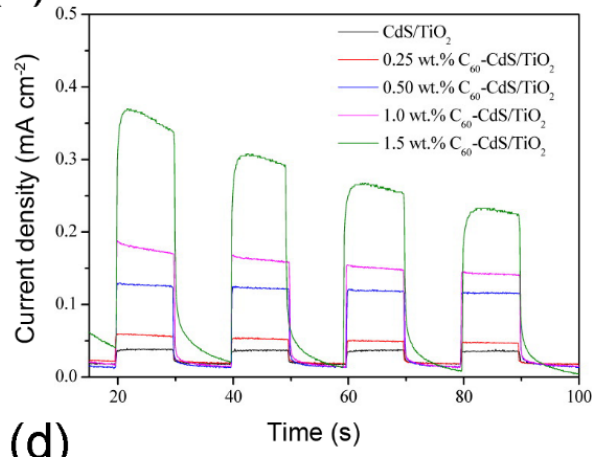

(d)

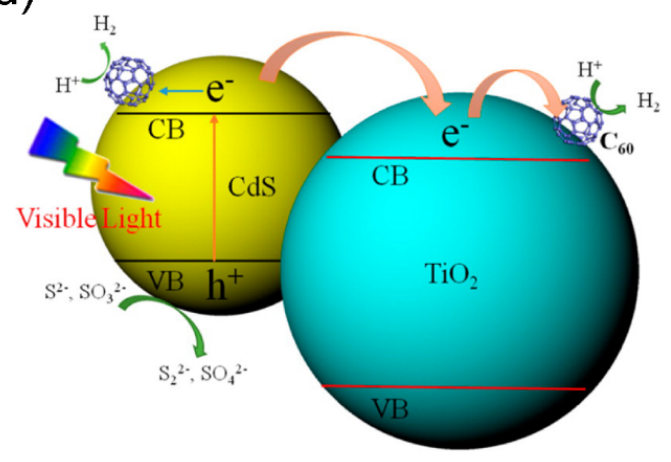

Figure 4. UV-vis spectra (a), photocurrent density measured at $0.5 \mathrm{~V}$ in a $0.5 \mathrm{M}$ aqueous $\mathrm{Na}_{2} \mathrm{SO}_{4}$ electrolyte (b) and PL spectra (c) excited by $280 \mathrm{~nm}$ of $\mathrm{CdS} / \mathrm{TiO}_{2}$ and $\mathrm{C}_{60}-\mathrm{CdS} / \mathrm{TiO}_{2}$ nanocomposites. (d) The mechanism of photocatalytic $\mathrm{H}_{2}$ generation over $\mathrm{C}_{60}-\mathrm{CdS} / \mathrm{TiO}_{2}$. Reproduced with permission from Reference [84]. Copyright 2015, ACS.

Fullerenol $\left(\mathrm{C}_{60}(\mathrm{OH})_{\mathrm{x}}\right)$, also called polyhydroxyfullerene $(\mathrm{PHF})$, is a water-soluble fullerene derivative $[99,100]$. Typically, PHF could be prepared using fullerene via acid hydrolysis or alkali hydrolysis method [101-103]. In the earlier time, Krishna and his co-workers found that the addition of PHF in solution could elevate the photocatalytic activity of $\mathrm{TiO}_{2}$ under UV light illumination [104]. The reaction solution with $\mathrm{PHF}+\mathrm{TiO}_{2}$ showed 2.6 times faster of photocatalytic organic dye degradation and 1.9 times faster of Escherichia coli inactivation than that of solution with $\mathrm{TiO}_{2}$ alone. While the hydroxylated fullerene (PHF) changes the electronic properties and decreases the electron affinity of fullerene, further studies were conducted by his group to explore the mechanisms of PHF to enhance the photocatalytic activity of $\mathrm{TiO}_{2}$ [105]. It was proposed that PHF covers onto the surface of $\mathrm{TiO}_{2}$ by electrostatic interactions in solution. The electron paramagnetic resonance (EPR) results showed that higher production rate of $\bullet \mathrm{OH}$ was achieved under UV light after addition of PHF in solution, which contributed to enhancement of $\mathrm{TiO}_{2}$ photocatalytic activity. However, PHF alone in solution did not generate $\bullet \mathrm{OH}$ under UV light, which suggested that synergistic effects come into being between $\mathrm{PHF}$ and $\mathrm{TiO}_{2}$. A hypothesis was proposed that PHF can scavenge the photo-generated electrons from $\mathrm{TiO}_{2}$ and meanwhile the synergistic effects of $\mathrm{PHF}$ and $\mathrm{TiO}_{2}$ can induce more $\bullet \mathrm{OH}$ generation for enhancing the photodegradation activity. Furthermore, Park, et al. [106] proposed a new approach of

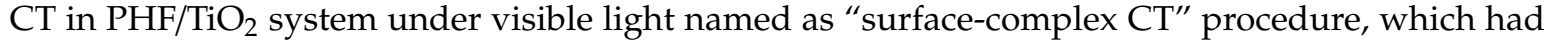
not yet been proposed in $\mathrm{TiO}_{2} / \mathrm{C}_{60}$ system before. Note that fullerol has numerous hydroxyl groups which may link to the surface of $\mathrm{TiO}_{2}$ through the CT-complex route (Equation (4)). The photocurrents $\left(\mathrm{I}_{\mathrm{ph}}\right)$ of the $\mathrm{PHF} / \mathrm{TiO}_{2}$-coated electrodes were examined, confirming that the transfer orientation of photogenerated electrons was from $\mathrm{PHF}$ to $\mathrm{TiO}_{2}$. In such surface-complex CT procedure, PHF serves as a photosensitizer in which electrons could be excited into $\mathrm{CB}$ of $\mathrm{TiO}_{2}$ under visible light irradiation, hence elevating the photocatalytic efficiency of $\mathrm{TiO}_{2}$. The reaction mechanism of radical generation is 
presented in Equations (5)-(8). Similar CT situations have been proposed in benzene/ $/ \mathrm{TiO}_{2}$ system and even polycyclic aromatic hydrocarbons $(\mathrm{PAH})$ physical-adsorbed $\mathrm{TiO}_{2}$ system as well $[107,108]$.

$$
\begin{gathered}
\mathrm{C}_{60}(\mathrm{OH})_{\mathrm{x}}+\equiv \mathrm{Ti}-\mathrm{OH} \rightarrow \equiv \mathrm{Ti}-\mathrm{O}-\mathrm{C}_{60}(\mathrm{OH})_{\mathrm{x}-1}+\mathrm{H}_{2} \mathrm{O} \\
\text { Fullerol } / \mathrm{TiO}_{2}+h v(\lambda>420 \mathrm{~nm}) \rightarrow\left(\text { fullerol }^{\bullet}\right) / \mathrm{TiO}_{2}\left(\mathrm{e}_{\mathrm{cb}}{ }^{-}\right) \\
\left(\text {fullerol }^{\bullet+}\right) / \mathrm{TiO}_{2}\left(\mathrm{e}_{\mathrm{cb}}{ }^{-}\right) \rightarrow \text { fullerol } / \mathrm{TiO}_{2} \\
\text { Fullerol } / \mathrm{TiO}_{2}\left(\mathrm{e}_{\mathrm{cb}}{ }^{-}\right) \rightarrow \mathrm{TiO}_{2} /(\text { fullerol } \\
\end{gathered}
$$

Bai, Krishna, Wang, Moudgil and Koopman [80] assembled a $\mathrm{PHF} / \mathrm{TiO}_{2}$ nanocomposite by a physically mixing method in aqueous suspension and then coated the as-prepared sample onto grout substrate to examine its photocatalytic activity. The nanocomposite coating at a $\mathrm{TiO}_{2} / \mathrm{PHF}$ ratio of 0.01 exhibited the best photocatalytic efficiency under UV light irradiation. Accordingly, the $0.01 \mathrm{TiO}_{2} / \mathrm{PHF}$ photocatalyst coating exhibited 2 times higher of Procion red MX-5B photocatalytic degradation efficiency and 3 times higher of photocatalytic spores of Aspergillus niger inactivation than these of bare $\mathrm{TiO}_{2}$ coating. Similarly, Hamandi, Berhault, Dappozze, Guillard and Kochkar [59] fabricated $\mathrm{TiO}_{2} / \mathrm{PHF}$ nanotubes using $\mathrm{PHF}$ and $\mathrm{TiO}_{2}$ nanotubes via wetness impregnation together with heat treated at $400{ }^{\circ} \mathrm{C}$ Under UV light illumination, the optimum $1 \% \mathrm{TiO}_{2} / \mathrm{PHF}$ nanotubes showed a rate constant values $\left(\mathrm{K}_{\exp }\right)$ of $94.7 \mu \mathrm{molL}^{-1} \mathrm{~min}^{-1}$ for photocatalytic degradation towards formic acid, while $\mathrm{TiO}_{2}$ nanotubes alone exhibited the $\mathrm{K}_{\exp }$ of $72.6 \mu \mathrm{molL}^{-1} \mathrm{~min}^{-1}$. Moreover, $\mathrm{Lim}$, Monllor-Satoca, Jang, Lee and Choi [81] developed a $\mathrm{Nb}^{-\mathrm{TiO}_{2}} /$ fullerol nanocomposite, which proved an elevated visible-light-driven photocatalytic performance. In brief, $\mathrm{Nb}$-doped $\mathrm{TiO}_{2}$ was fabricated by a sol-gel method then the $\mathrm{Nb}-\mathrm{TiO}_{2}$ was dispersed into fullerol solution buffered at $\mathrm{pH} 3$ with $\mathrm{HClO}_{4}$. After stirring for $3 \mathrm{~h}$, the filtered solids were dried at $80^{\circ} \mathrm{C}$ to acquire brownish particles designated as $\mathrm{Nb}-\mathrm{TiO}_{2} /$ fullerol. The $\mathrm{Nb}-\mathrm{TiO}_{2} /$ fullerol showed more effectively photocatalytic performance for the reduction of $\mathrm{Cr}(\mathrm{VI})$, oxidation of iodide and degradation of 4-chlorophenol than naked $\mathrm{TiO}_{2}, \mathrm{Nb}-\mathrm{TiO}_{2}$ and $\mathrm{TiO}_{2} /$ fullerol under visible light. These results indicated that the synergistic effects between fullerol and $\mathrm{Nb}$ improved the photocatalytic activity of $\mathrm{TiO}_{2}$. It was proved that $\mathrm{Nb}$ doping induced vacancies of $\mathrm{TiO}_{2}$ by ionic substitution of $\mathrm{Nb}^{5+}$ in $\mathrm{Ti}^{4+}$ position, which could suppress the photoinduced hole-electron pairs recombination by trapping electrons. Notably, the fullerol significantly enhanced the visible light absorption of $\mathrm{Nb}-\mathrm{TiO}_{2}$ through a surface-complex $\mathrm{CT}$ mechanism. Under visible light irradiation, electrons will be excited from $\mathrm{HOMO}$ of fullerol to $\mathrm{CB}$ of $\mathrm{TiO}_{2}$ and then from $\mathrm{CB}$ to vacancies, which effectively enhances the charge transport and prolongs the lifetime of photoinduced carriers. Another advantage was proposed that the $\mathrm{Nb}-\mathrm{TiO}_{2} /$ fullerol showed more highly photochemical stability over typical dye-sensitized- $\mathrm{TiO}_{2}$.

\subsection{Metal Oxides (except $\mathrm{TiO}_{2}$ )/Fullerene Photocatalyst}

In addition to $\mathrm{TiO}_{2}$, other metal oxides have also been promising materials in photocatalytic application [109-111]. Fullerene $\left(\mathrm{C}_{60}\right.$ and $\left.\mathrm{C}_{70}\right)$ has some advantages to enhance the photocatalytic efficiency of these metal oxides, such as enhancing the light absorption and inhibiting recombination of photogenerated hole-electron pairs. Accordingly, a number of metal-oxide/fullerene photocatalysts have been successfully synthesized and extensively applied in photocatalytic pollutant degradation and $\mathrm{H}_{2}$ evolution via water splitting, such as $\mathrm{ZnO} / \mathrm{C}_{60}\left(\mathrm{C}_{70}\right), \mathrm{WO}_{3} / \mathrm{C}_{60}$ and $\mathrm{SnO}_{2} / \mathrm{C}_{60}$ [25,112].

Similar to $\mathrm{TiO}_{2}, \mathrm{ZnO}$ is an alternative photocatalyst with a band gap of $3.3 \mathrm{eV}$ [113]. Generally, the absorption edge of pristine $\mathrm{ZnO}$ locates the near $\mathrm{UV}$ region, which usually restricts its photocatalytic efficiency. Meanwhile, the susceptibility to photocorrosion is also another barrier of $\mathrm{ZnO}$ for satisfactory photocatalytic performance. $\mathrm{Fu}, \mathrm{Xu}, \mathrm{Zhu}$ and $\mathrm{Zhu}$ [70] successfully prepared a $\mathrm{C}_{60}$ hybridized $\mathrm{ZnO}$ nanocomposite by a simple absorption method, and the sample with $1.5 \mathrm{wt} \% \mathrm{C}_{60}$ exhibited the 
best photocatalytic sufficiency in MB degradation. The $1.5 \mathrm{wt} \% \mathrm{ZnO} / \mathrm{C}_{60}$ composite showed $95 \%$ photocatalytic degradation sufficiency towards MB under UV light, which was 3-times as high as that of bare ZnO. In such system, the elevated performance was ascribed to the improved light adsorption and a higher separation efficiency of photoinduced hole-electron pairs. During the photocatalysis process, the photogeneration holes could easily react with surface oxygen atom, leading to fast decline of photocatalytic activity of $\mathrm{ZnO}$. When $\mathrm{C}_{60}$ was covered on $\mathrm{ZnO}$, the activity of surface oxygen atoms was effectively reduced so that more holes could participate in photocatalytic reaction. Furthermore, the photocorrosion experiment indicated that the $\mathrm{C}_{60}$-hybridized $\mathrm{ZnO}$ nanocomposite did not show obviously decline of photocatalytic sufficiency even after illumination under UV light for $50 \mathrm{~h}$, which was highly superior in stabilization than bare ZnO. Hence, the introduction of $\mathrm{C}_{60}$ effectually suppress photocorrosion of ZnO. Similarly, Hong, et al. [114] successfully prepared a $\mathrm{ZnO} / \mathrm{C}_{70}$ nanocomposite via a heat treatment method, which exhibited superior photocatalytic degradation of organic dyes.

Recently, Tahir, Nabi, Rafique and Khalid [53] proposed the elevated photocatalytic efficiency of $\mathrm{WO}_{3} / \mathrm{C}_{60}$ nanocomposite for dye degradation and $\mathrm{H}_{2}$ evolution. The optimized $4 \mathrm{wt} \% \mathrm{WO}_{3} / \mathrm{C}_{60}$ sample showed the best photodegradation ability and the degradation efficiency in $\mathrm{MB}, \mathrm{RhB}$ and $\mathrm{MO}$ under visible light illumination was $93 \%, 92 \%$ and $91 \%$, respectively. Meanwhile, the $\mathrm{H}_{2}$ evolution rate of the $4 \mathrm{wt} \% \mathrm{WO}_{3} / \mathrm{C}_{60}$ was 2-times higher than that of bare $\mathrm{WO}_{3}$. After coupling with $\mathrm{C}_{60}$, the band gap of $\mathrm{WO}_{3} / \mathrm{C}_{60}$ nanocomposites were lower than that of bare $\mathrm{WO}_{3}$, which could excite more electrons of semiconductor $\mathrm{WO}_{3}$ from VB to CB. The BET surface area of these composites was also significantly increased, which could enhance the adsorption reaction. Based on the aforementioned study, Shahzad, Tahir and Sagir [87] constructed a novel heterogeneous photocatalyst $\mathrm{WO}_{3} /$ fullerene@Ni $3 / \mathrm{Ni}(\mathrm{OH})_{2}$ for $\mathrm{H}_{2}$ production. As a co-catalyst, $\mathrm{Ni} 3 \mathrm{~B} / \mathrm{Ni}(\mathrm{OH})_{2}$ was loaded onto $\mathrm{WO}_{3} /$ fullerene thin film by a facile photo-deposition technique. The optimal $\mathrm{WO}_{3} /$ fullerene@1.5\%Ni $3 \mathrm{~B} / \mathrm{Ni}(\mathrm{OH})_{2}$ presented an outstanding photocatalytic efficiency in $\mathrm{H}_{2}$ generation, reaching $1578 \mu \mathrm{mol} \mathrm{h}^{-1} \mathrm{~g}^{-1}$. In this system, it was proposed that three factors mainly contributed to the superior performance, including inhibition for recombination of photogeneration hole-electron pairs, more active sites for photocatalytic reaction and synergistic effect between nanocomposite and co-catalyst. Even earlier, a ternary photocatalyst $\mathrm{WO}_{3} / \mathrm{C}_{60} / \mathrm{TiO}_{2}$ was successfully prepared via a sol-gel method. Its photocatalytic performance in $\mathrm{MO}$ degradation was higher than that of $\mathrm{WO}_{3} / \mathrm{C}_{60}$ or $\mathrm{TiO}_{2} / \mathrm{C}_{60}$, which means these three materials synergistically enhance the photocatalytic activity [78].

In addition, Song, Zhang, Zeng, Wang, Ali and Zeng [83] fabricated a series $\mathrm{C}_{60}$ modified $\mathrm{Fe}_{2} \mathrm{O}_{3}$ polymorphs $\left(\alpha-, \gamma\right.$ - and $\left.\beta-\mathrm{Fe}_{2} \mathrm{O}_{3}\right)$ photocatalysts via a simple adsorption method. These as-prepared samples showed superior photocatalytic efficiency in $\mathrm{H}_{2}$ production and even extremely outstanding effects were observed in the presence of fluorescein. Under visible light irradiation, the photocatalytic capacity was in the order: $1 \mathrm{C}_{60} / \beta-\mathrm{Fe}_{2} \mathrm{O}_{3}>1 \mathrm{C}_{60} / \gamma-\mathrm{Fe}_{2} \mathrm{O}_{3}>\gamma-\mathrm{Fe}_{2} \mathrm{O}_{3}>1 \mathrm{C}_{60} / \alpha-\mathrm{Fe}_{2} \mathrm{O}_{3}>\beta-\mathrm{Fe}_{2} \mathrm{O}_{3}>g-\mathrm{C}_{3} \mathrm{~N}_{4}$ $>\alpha-\mathrm{Fe}_{2} \mathrm{O}_{3}$. Behera, Mansingh, Das and Parida [71] proposed a $\mathrm{ZnFe}_{2} \mathrm{O}_{4}$-fullerene photocatalyst for norfloxacin decomposition and $\mathrm{Cr}$ (VI) reduction, wherein fullerene introducing significantly improved the photocatalytic capacity of $\mathrm{ZnFe}_{2} \mathrm{O}_{4}$. Moreover, Song, Huo, Liao, Zeng, Qin and Zeng [82] successfully prepared a novel photocatalyst $\mathrm{Cr}_{2-\mathrm{x}} \mathrm{Fe}_{\mathrm{x}} \mathrm{O}_{3} / \mathrm{C}_{60}$ via a simple adsorption method. In this study, $\alpha-\mathrm{Fe}_{2} \mathrm{O}_{3}(\sim 2.2 \mathrm{eV})$ and $\mathrm{Cr}_{2} \mathrm{O}_{3}(\sim 3.4 \mathrm{eV})$ were integrated through a sol-gel method in order to construct $\mathrm{Cr}_{2-x} \mathrm{Fe}_{\mathrm{x}} \mathrm{O}_{3}$ with a suitable band gap for $\mathrm{H}_{2}$ generation. While poor electron conducting ability limited its further application, the introducing of $\mathrm{C}_{60}$ was an effective way. The optimal $3 \% \mathrm{C}_{60} / \mathrm{Cr}_{1.3} \mathrm{Fe}_{0.7} \mathrm{O}_{3}$ sample presented the $\mathrm{H}_{2}$ generation rate of $220.5 \mu \mathrm{mol} \mathrm{h}{ }^{-1} \mathrm{~g}^{-1}$, which was about 2-times of the bare $\mathrm{Cr}_{1.3} \mathrm{Fe}_{0.7} \mathrm{O}_{3}$ composite.

\subsection{Metal Sulfide/Fullerene Nanocomposites}

Nowadays, metal sulfide semiconductors have attracted extensive attentions in photocatalytic application due to their distinctive optical-electrical characteristic [115-117]. CdS is an appealing photocatalyst with narrow bandgap (2.2 2.4 eV) exhibiting superior visible-light respond [118]. 
While fast recombination of hole-electron pairs and photocorrosion effect are the two main obstacles of naked CdS, which inhibits its photocatalytic efficiency. Coupling with fullerene was proved to be an effective way to boost the photocatalytic performance of CdS. Accordingly, Cai, Hu, Zhang, $\mathrm{Li}$ and Shen [43] successfully assembled a $\mathrm{CdS} / \mathrm{C}_{60}$ nanocomposite via one-pot hydrothermal synthesis. The as-prepared samples showed better separation efficiency of photoinduced hole-electron pairs and higher photocurrent density than pure CdS (Figure 5a,b). Thus, the improvement of the aforementioned features contributed to a highly photocatalytic activity over $\mathrm{CdS} / \mathrm{C}_{60}$ nanocomposite. The optimal $\mathrm{H}_{2}$ production rate of $0.4 \mathrm{wt} \% \mathrm{CdS} / \mathrm{C}_{60}$ was $1.73 \mathrm{mmol} \mathrm{h}^{-1} \mathrm{~g}^{-1}$ under visible light illumination, which was 2.3-times higher than that of naked CdS (Figure $5 \mathrm{c}$ ). Its photocatalytic degradation efficiency towards RhB achieved $97 \%$ in 40 min (Figure 5d). Furthermore, the photostability of CdS was significantly boosted after $\mathrm{CdS}$ combining with $\mathrm{C}_{60}$, and $97.8 \%$ of RhB degradation efficiency actually retained after three recycles (Figure $5 \mathrm{e}$ ). In order to estimate the stability of $\mathrm{CdS} / \mathrm{C}_{60}$, the released $\mathrm{Cd}^{2+}$ concentration was determined in remaining solution after three cycles for RhB degradation (Figure $5 \mathrm{f}$ ). The $\mathrm{Cd}^{2+}$ concentration was $381.3 \mu \mathrm{g} / \mathrm{L}$ in solution with naked CdS while it was $51.9 \mu \mathrm{g} / \mathrm{L}$ in solution with $0.4 \mathrm{wt} \% \mathrm{CdS} / \mathrm{C}_{60}$ nanomaterial, in which the former was 7.3 times of the later. The results above indicated that $\mathrm{C}_{60}$ could effectively inhibit the photocorrosion and boost the stability of CdS. Furthermore, Meng, Peng, Zhu, Oh and Zhang [56] assembled a novel ternary $\mathrm{CdS}_{\mathrm{TiO}} / \mathrm{C}_{60}$ photocatalyst via a sol-gel method. The introduction of $\mathrm{C}_{60}$ definitely induced $56 \%$ increasement of the BET surface of the $\mathrm{CdS} / \mathrm{TiO}_{2}$ composite, which could enhance the adsorption effect. Under the same condition, the $\mathrm{MO}$ degradation rate $(\mathrm{K})$ of these nanocomposites was in an order: $\mathrm{CdS} / \mathrm{TiO}_{2} / \mathrm{C}_{60}>$ $\mathrm{TiO}_{2} / \mathrm{C}_{60}>\mathrm{TiO}_{2}>\mathrm{CdS} / \mathrm{TiO}_{2}$. This meant the $\mathrm{CdS} / \mathrm{TiO}_{2} / \mathrm{C}_{60}$ composite obtained superior photocatalytic capacity owing to the synergistic reaction of $\mathrm{C}_{60}, \mathrm{TiO}_{2}$ and $\mathrm{CdS}$. It was concluded in this study that the synergistic effects were as follows: (1) $C_{60}$ could increase the quantum efficiency and charge transfer, as well as enhance the adsorption effect of the ternary photocatalyst; (2) Combining CdS with $\mathrm{TiO}_{2}$ endows the photocatalyst with a suitable bandgap for visible-light respond and a more effective electron transfer route for generating more $\bullet \mathrm{OH}$ and $\bullet \mathrm{O}_{2}{ }^{-}$.

In addition, Meng and co-workers assembled $\mathrm{CoS} / \mathrm{C}_{60}$ and $\mathrm{AgS} / \mathrm{C}_{60}$ nanocomposites for pollutant decomposition $[52,119]$. Superior photocatalytic efficiency was obtained in these photocatalysts after the introduction of $\mathrm{C}_{60}$, since $\mathrm{C}_{60}$ is an energy sensitizer that could improve the quantum efficiency and boost charge transfer efficiency. More recently, Guan, Wu, Jiang, Zhu, Guan, Lei, Du, Zeng and Yang [54] fabricated a $\mathrm{MoS}_{2} / \mathrm{C}_{60}$ heterostructure photocatalyst via a ball milling method. The method does not need solvent to dissolve $\mathrm{MoS}_{2}$ and $\mathrm{C}_{60}$ and can significantly increase the BET surface of product. In this study, it was the first time to propose that a van der Waals heterostructure formed between $\mathrm{MoS}_{2}$ and $\mathrm{C}_{60}$ through ball milling, detailly wherein $\mathrm{C}_{60}$ nanoparticles bounded onto the edge of the exfoliated $\mathrm{MoS}_{2}$ nanosheet by non-covalent bond. Noteworthily, the $\mathrm{CB}$ minimum of $\mathrm{MoS}_{2} / \mathrm{C}_{60}$ was more negative than that of ball-milled $\mathrm{MoS}_{2}$ and the VB maximum of the former was more positive than that of the later. Thus, the as-prepared $\mathrm{MoS}_{2} / \mathrm{C}_{60}$ photocatalyst featured more suitable band gap for elevating the $\mathrm{H}_{2}$ evolution. Under visible light irradiation, the optimal $2.8 \mathrm{wt} \% \mathrm{MoS}_{2} / \mathrm{C}_{60}$ sample exhibited the photocatalytic $\mathrm{H}_{2}$ production rate of $6.89 \mathrm{mmol} \mathrm{h}^{-1} \mathrm{~g}^{-1}$ in the presence of EY as a photosensitizer, which was 9.5 times higher than that of ball-milled $\mathrm{MoS}_{2}$ without $\mathrm{C}_{60}$. 
(a)

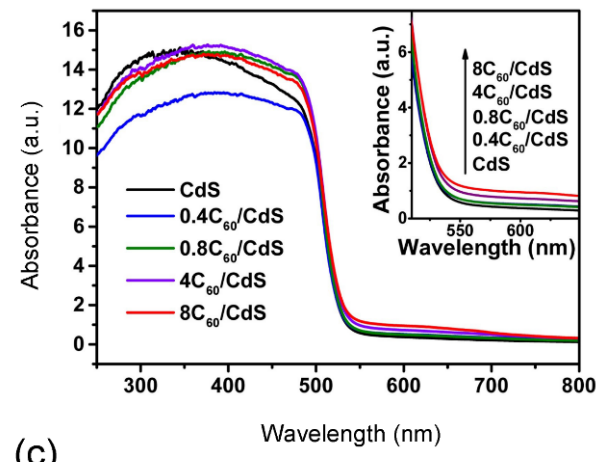

(c)

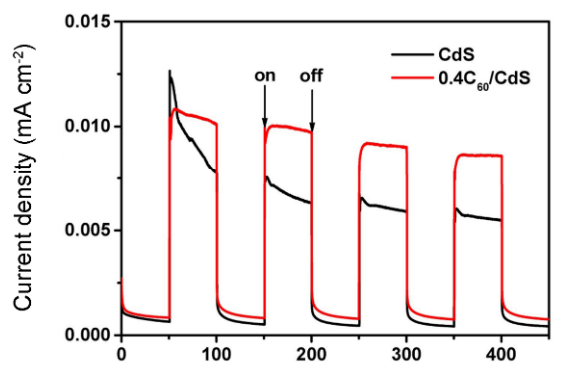

(e)

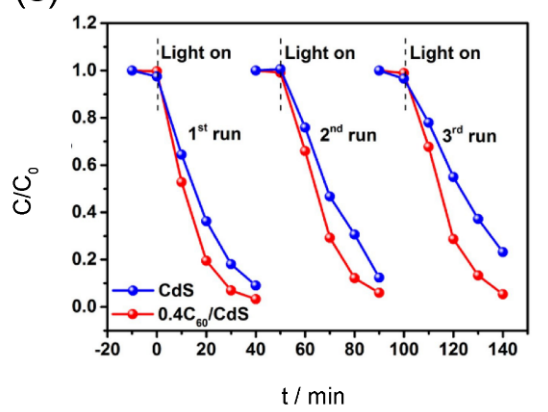

(b)

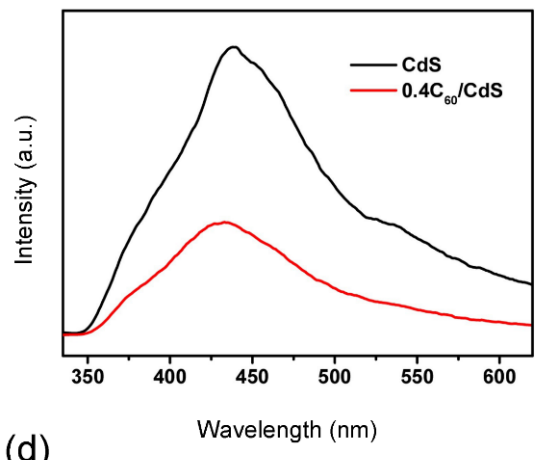

(d)

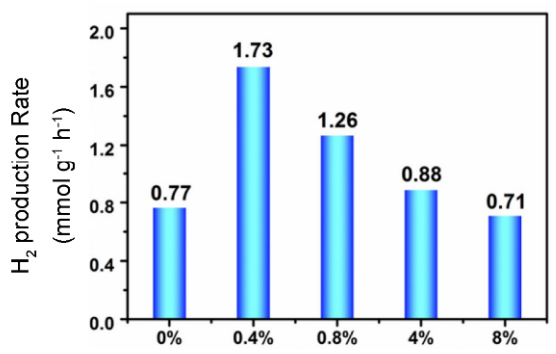

(f)

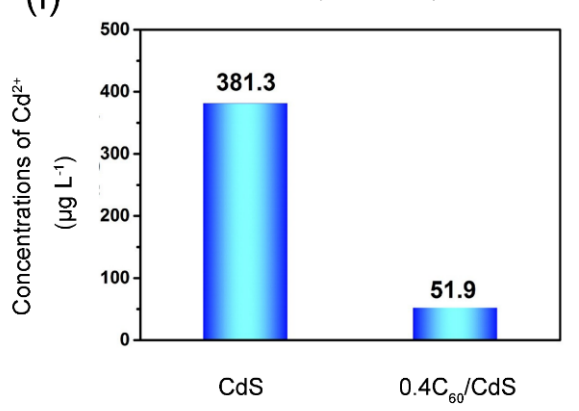

Figure 5. UV-vis spectra (a), PL emission spectra (b) and transient photocurrent responses (c) in $0.5 \mathrm{M} \mathrm{Na}_{2} \mathrm{SO}_{4}$ solution of $\mathrm{CdS}$ and $\mathrm{C}_{60} / \mathrm{CdS}$ nanocomposites. (d) The photocatalytic rate of $\mathrm{H}_{2}$ generation over $\mathrm{C}_{60} / \mathrm{CdS}$ samples under visible light illumination. (e) Recyclability test of photodegradation towards $\mathrm{RhB}$ under visible light illumination over $\mathrm{CdS}$ and $0.4 \mathrm{C}_{60} / \mathrm{CdS}$ composite. (f) Comparison of $\mathrm{Cd}^{2+}$ concentrations in the solutions of $\mathrm{CdS}$ and $0.4 \mathrm{C}_{60} / \mathrm{CdS}$ photocatalysts after three cycles for RhB degradation. Reproduced with permission from Reference [43]. Copyright 2017, Elsevier.

\subsection{Bismuth-Based Semiconductor/Fullerene Composites}

Bismuth-based semiconductors have been proven promising materials for photocatalytic application, including $\mathrm{BiOX}(\mathrm{X}=\mathrm{Br}, \mathrm{Cl}$ and $\mathrm{I}), \mathrm{Bi}_{2} \mathrm{WO}_{6}, \mathrm{BiVO}_{4}, \mathrm{Bi}_{2} \mathrm{MoO}_{6}$, and so on $[2,120,121]$. Considerable research efforts have been devoted to couple these bismuth-based semiconductors with fullerene $\left(\mathrm{C}_{60}\right.$ or $\left.\mathrm{C}_{70}\right)$ and enhanced photocatalytic performance could be obtained. For example, $\mathrm{Zhu}, \mathrm{Xu}, \mathrm{Fu}$, Zhao and $\mathrm{Zhu}[40]$ successfully prepared $\mathrm{C}_{60}$ modified $\mathrm{Bi}_{2} \mathrm{WO}_{6}$ photocatalyst via a simple absorbing process, and $1.25 \mathrm{wt} \% \mathrm{Bi}_{2} \mathrm{WO}_{6} / \mathrm{C}_{60}$ displayed 5.0-times the photocatalytic degradation activity towards $\mathrm{MB}$ with respect to unmodified $\mathrm{Bi}_{2} \mathrm{WO}_{6}$. Similarly, Ma, Zhong, $\mathrm{Li}$, Wang and Peng [39] fabricated $\mathrm{C}_{70}$ modified $\mathrm{BiOCl}$ by an in-situ preparation procedure and superior photocatalytic performance was observed. Under solar irradiation for $30 \mathrm{~min}, 49.7 \%$ of $\mathrm{RhB}$ was degraded over pure $\mathrm{BiOCl}$ while $99.8 \%$ of $\mathrm{RhB}$ could be degraded over $1 \mathrm{wt} \% \mathrm{BiOCl} / \mathrm{C}_{70}$. In addition, $\mathrm{Li}$, Jiang, Li, Lian, Xiao, Zhu, Zhang and $\mathrm{Li}\left[73\right.$ ] successfully developed $\mathrm{Bi}_{2} \mathrm{TiO}_{4} \mathrm{~F}_{2} / \mathrm{C}_{60}$ photocatalyst via a solvothermal method, which was a hierarchical microsphere structure. The introduction of $\mathrm{C}_{60}$ can increase the photocurrent of the as-prepared sample, resulting from more efficient mobility efficiency of the charge 
carriers (Figure 6a). Owing to strong combining and heterojunction formation, the $\mathrm{Bi}_{2} \mathrm{TiO}_{4} \mathrm{~F}_{2} / \mathrm{C}_{60}$ nanocomposite showed obviously elevated photocatalytic capacity for degrading $\mathrm{RhB}$ relative to bare $\mathrm{Bi}_{2} \mathrm{TiO}_{4} \mathrm{~F}_{2}$ under visible light irradiation (Figure 6b). Meanwhile, the photocatalyst exhibited excellent stabilization as well and highly photocatalytic efficiency of $\mathrm{RhB}$ degradation $(\approx 80 \%)$ was maintained even after eight circles (Figure $6 \mathrm{c}$ ). The photocatalytic mechanisms of $\mathrm{Bi}_{2} \mathrm{TiO}_{4} / \mathrm{C}_{60}$ nanocomposite are described in Figure 6d. Apart from organic pollutant, bromate $\left(\mathrm{BrO}^{3-}\right)$ also exhibits biotoxicity to aquatic organisms and human since its properties non-biodegradation and accumulation. A strategy for controlling $\mathrm{BrO}^{3-}$ pollution is to reduce it to $\mathrm{Br}^{-}$which is naturally present in surface water bodies. Therefore, Zhao, $\mathrm{Liu}$, Shen and $\mathrm{Qu}[46]$ studied the photocatalytic performance of $\mathrm{Bi}_{2} \mathrm{MoO}_{6} / \mathrm{C}_{60}$ for removal $\mathrm{BrO}^{3-}$ under visible light. After modification with $\mathrm{C}_{60}, \mathrm{Bi}_{2} \mathrm{MoO}_{6} / \mathrm{C}_{60}$ exhibited sharply increase in photocatalytic reduction of $\mathrm{BrO}^{3-}$, attributed to the enhanced separation rate of photogenerated electron-hole pairs.

\subsection{Carbon Nitride/Fullerene Composites}

Graphitic carbon nitride $\left(\mathrm{g}-\mathrm{C}_{3} \mathrm{~N}_{4}\right)$ is an attractive metal-free photocatalyst, which was developed by Wang et al. in 2009 [122]. The pristine g- $\mathrm{C}_{3} \mathrm{~N}_{4}$ features a medium band gap (2.5 2.7 eV) with good visible light response [123]. Currently, this effective organo-photocatalyst has been widely used for pollutant degradation, water splitting and $\mathrm{CO}_{2}$ reduction [124,125]. However, pristine $\mathrm{g}-\mathrm{C}_{3} \mathrm{~N}_{4}$ exhibits insufficient solar absorption and rapid recombination of photogenerated carriers, which limits its photocatalytic efficiency. It has been proven that coupling $g-\mathrm{C}_{3} \mathrm{~N}_{4}$ with fullerene is an effective way to enhance the photocatalytic sufficiency in pollutant degradation and $\mathrm{H}_{2}$ evolution. Recently, a series of $\mathrm{g}-\mathrm{C}_{3} \mathrm{~N}_{4} /$ fullerene nanocomposites have been fabricated and they showed elevated photocatalytic efficiency.

Chai, Liao, Song and Zhou [45] prepared g- $\mathrm{C}_{3} \mathrm{~N}_{4} / \mathrm{C}_{60}$ nanocomposites via a simple adsorption method. After $\mathrm{C}_{60}$ introduction, $\mathrm{g}-\mathrm{C}_{3} \mathrm{~N}_{4} / \mathrm{C}_{60}$ nanocomposites enhanced the visible light absorption without changing the absorption edge of $\mathrm{g}-\mathrm{C}_{3} \mathrm{~N}_{4}$, as well as lowered the recombination of photogenerated hole-electron pairs. The $1 \mathrm{wt} \% \mathrm{C}_{3} \mathrm{~N}_{4} / \mathrm{C}_{60}$ showed the highest photodegradation performance towards $\mathrm{RhB}$, which could reach $97 \%$ degradation efficiency under visible light after $60 \mathrm{~min}$. The reaction process could be proposed as follows (Equations (9)-(12)):

$$
\begin{gathered}
\mathrm{C}_{60} / \mathrm{C}_{3} \mathrm{~N}_{4}{ }^{h} \rightarrow{ }^{v} \mathrm{C}_{60}\left(\mathrm{e}^{-}\right) / \mathrm{C}_{3} \mathrm{~N}_{4}\left(\mathrm{~h}^{+}\right) \\
\mathrm{C}_{60}\left(\mathrm{e}^{-}\right)+\mathrm{O}_{2} \rightarrow \mathrm{C}_{60}+{ }^{\bullet} \mathrm{O}_{2}^{-} \\
\mathrm{O}_{2}{ }^{-}+2 \mathrm{e}^{-}+2 \mathrm{H}^{+} \rightarrow{ }^{\bullet} \mathrm{OH}+\mathrm{OH}^{-} \\
\mathrm{RhB}+\mathrm{h}^{+}\left({ }^{\bullet} \mathrm{OH},{ }^{\bullet} \mathrm{O}_{2}^{-}\right) \rightarrow \text { products }
\end{gathered}
$$

Bai, Wang, Wang, Yao and Zhu [35] introduced $C_{60}$ into g- $C_{3} N_{4}$ matric via thermal treatment of $C_{60}$ and dicyandiamide mixture at $550^{\circ} \mathrm{C}$ and the obtained nanocomposites exhibited higher photooxidation degradation efficiency towards phenol and MB. Relative to physical blend, this thermal treatment gave rise to strong interface interaction between g- $C_{3} N_{4}$ and $C_{60}$. The g- $C_{3} N_{4} / C_{60}$ nanocomposite exhibited higher specific surface area than pristine g- $\mathrm{C}_{3} \mathrm{~N}_{4}$, leading to more active sites for catalytic reaction. The photocurrent value of $\mathrm{g}-\mathrm{C}_{3} \mathrm{~N}_{4} / \mathrm{C}_{60}$ is 4 .0-times that of g- $\mathrm{C}_{3} \mathrm{~N}_{4}$, which was highly responsible for enhancing the photocatalytic activity of pristine g- $\mathrm{C}_{3} \mathrm{~N}_{4}$. Moreover, the introduction of $\mathrm{C}_{60}$ decreased the band gap of $\mathrm{C}_{3} \mathrm{~N}_{4}$, wherein the value of g- $\mathrm{C}_{3} \mathrm{~N}_{4}$ and g- $\mathrm{C}_{3} \mathrm{~N}_{4} / \mathrm{C}_{60}$ were severally $2.70 \mathrm{eV}$ and $2.58 \mathrm{eV}$, respectively. The calculation results showed that the valence band maximum (VBM) of $C_{3} N_{4} / C_{60}$ is $0.17 \mathrm{~V}$ lower than that of $\mathrm{g}-\mathrm{C}_{3} \mathrm{~N}_{4}$, which meant a stronger oxidizing capacity. Under visible light, the degradation ability of g- $\mathrm{C}_{3} \mathrm{~N}_{4} / \mathrm{C}_{60}$ towards phenol and $\mathrm{MB}$ were 2.9- and 3.2-times as high as that of pristine g- $\mathrm{C}_{3} \mathrm{~N}_{4}$, respectively. In addition, a series of $\mathrm{C}_{3} \mathrm{~N}_{4} /$ fullerene $\left(\mathrm{C}_{60}, \mathrm{C}_{70}\right)$ photocatalysts were prepared by Ouyang, et al. [126] via a hydrothermal method for disinfection of bacterial pathogens under visible light irradiation. Regarding disinfection of E. coli O157:H7, both $C_{3} \mathrm{~N}_{4} / \mathrm{C}_{60}$ and $\mathrm{C}_{3} \mathrm{~N}_{4} / \mathrm{C}_{70}$ 
hybrids showed stronger bacterial inactivation than pristine $\mathrm{C}_{3} \mathrm{~N}_{4}$ after $4 \mathrm{~h}$ irradiation, and the $\mathrm{C}_{3} \mathrm{~N}_{4} / \mathrm{C}_{70}$ exhibited the best performance. Note that both $\bullet \mathrm{O}_{2}{ }^{-}$and $\bullet \mathrm{OH}$ were identified as radical species to destruct bacterial cell in the solution under the visible light irradiation.

(a)

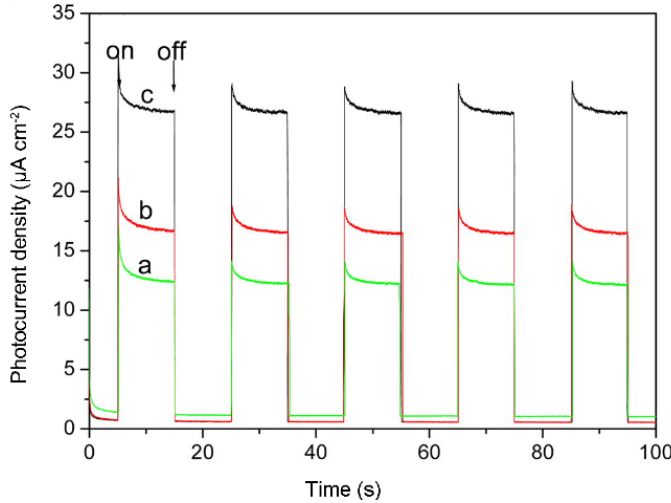

(c)

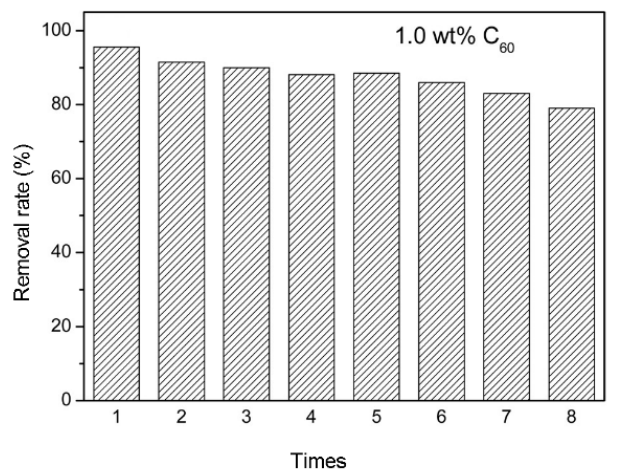

(b)

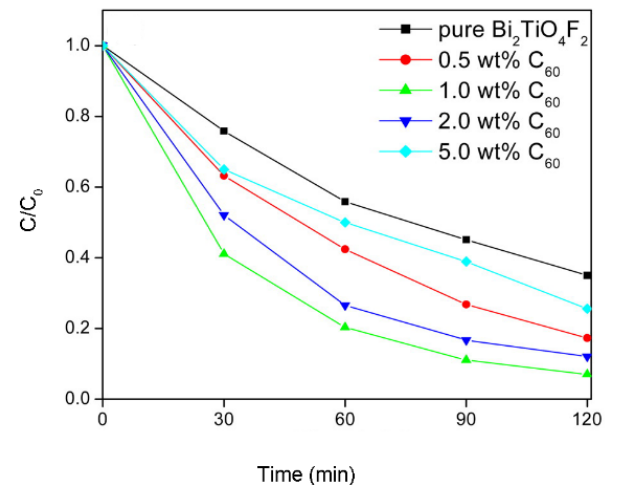

(d)

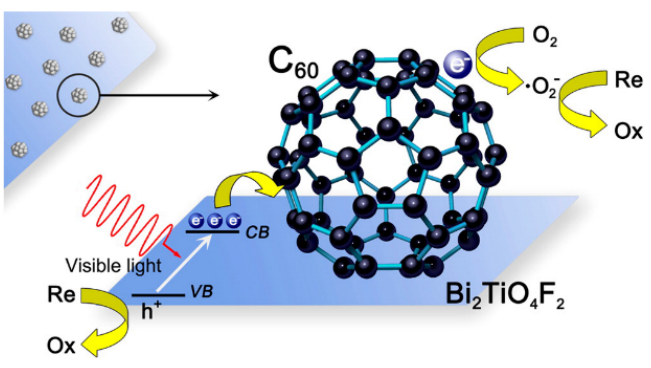

Figure 6. (a) Photocurrent responses of $\mathrm{Bi}_{2} \mathrm{TiO}_{4} \mathrm{~F}_{2}, \mathrm{C}_{60}(1 \mathrm{wt} \%)+\mathrm{Bi}_{2} \mathrm{TiO}_{4} \mathrm{~F}_{2}$ mixture and $1 \mathrm{wt} \% \mathrm{C}_{60} / \mathrm{Bi}_{2} \mathrm{TiO}_{4} \mathrm{~F}_{2}$. (b) Photocatalytic performance towards $\mathrm{RhB}$ degradation. (c) Recyclability test of the as-prepared composites $1 \mathrm{wt} \% \mathrm{C}_{60} / \mathrm{Bi}_{2} \mathrm{TiO}_{4} \mathrm{~F}_{2}$. (d) The mechanism of $\mathrm{C}_{60} / \mathrm{Bi}_{2} \mathrm{TiO}_{4} \mathrm{~F}_{2}$ photocatalyst is presented under visible light irradiation. Reproduced with permission from Reference [73]. Copyright 2013, ACS.

Coupling g- $\mathrm{C}_{3} \mathrm{~N}_{4}$ with $\mathrm{C}_{60}$ could elevate the photocatalytic ability to $\mathrm{H}_{2}$ generation as well. For instance, Chen, Chen, Guan, Zhen, Sun, Du, Lu and Yang [55] successfully synthesized a covalent bonding g- $\mathrm{C}_{3} \mathrm{~N}_{4} / \mathrm{C}_{60}$ nanocomposite via ball milling with $\mathrm{LiOH}$ as catalyst, which was the first time using this method for fabricating semiconductor/ $\mathrm{C}_{60}$ nanocomposite. As depicted in XRD image, the lattice structure of $\mathrm{g}-\mathrm{C}_{3} \mathrm{~N}_{4}$ nanomaterial was changed after the attachment of $\mathrm{C}_{60}$ component (Figure 7a). It was proven that the covalent bonds were formed in the $\mathrm{C}_{3} \mathrm{~N}_{4} / \mathrm{C}_{60}$ nanocomposite and a new peak at $399.5 \mathrm{eV}$ was detected in XPS spectra, which was ascribed to $\mathrm{N}-\mathrm{C}_{60}$ bond (Figure $7 \mathrm{~b}$ ). In this study, a new viewpoint was proposed that $\mathrm{C}_{60}$ forms covalent bond with $\mathrm{g}-\mathrm{C}_{3} \mathrm{~N}_{4}$ by a four-membered ring of azetidine. However, g- $\mathrm{C}_{3} \mathrm{~N}_{4} / \mathrm{C}_{60}$ alone hardly exhibited the photocatalytic capacity in $\mathrm{H}_{2}$ evolution, thus additional photosensitizer was necessary. Under visible light, the $\mathrm{H}_{2}$ generation rate of g- $\mathrm{C}_{3} \mathrm{~N}_{4} / \mathrm{C}_{60}$ was $266 \mu \mathrm{mol} \mathrm{h}^{-1} \mathrm{~g}^{-1}$ using EY as a photosensitizer, which was 4.0 times higher than that of g- $\mathrm{C}_{3} \mathrm{~N}_{4}$ in the same condition (Figure $7 \mathrm{c}$ ). As depicted in Figure $7 \mathrm{~d}$, the mechanisms of $\mathrm{g}-\mathrm{C}_{3} \mathrm{~N}_{4} / \mathrm{C}_{60}$ nanocomposite are described for photocatalytic $\mathrm{H}_{2}$ generation. Recently, a novel g- $\mathrm{C}_{3} \mathrm{~N}_{4} /$ graphene $/ \mathrm{C}_{60}$ composite was successfully prepared and significant enhancement for $\mathrm{H}_{2}$ evolution ability of the photocatalyst was observed [19]. In the presence of $\mathrm{Pt}$ (cocatalyst) and triethanolamine (sacrificial agent), the $\mathrm{H}_{2}$ evolution rate of the $\mathrm{g}-\mathrm{C}_{3} \mathrm{~N}_{4} /$ graphene/ $\mathrm{C}_{60}$ was $5449.5 \mu \mathrm{mol} \mathrm{g}^{-1}$ within $10 \mathrm{~h}$, which was 50.4 and 4.24 times that of g- $\mathrm{C}_{3} \mathrm{~N}_{4} /$ graphene and g- $\mathrm{C}_{3} \mathrm{~N}_{4} / \mathrm{C}_{60}$, respectively. It means that $\mathrm{C}_{60}$ and graphene 
mutually reinforced synergy in $\mathrm{H}_{2}$ generation of g- $\mathrm{C}_{3} \mathrm{~N}_{4}$, owing to high conductivity of graphene and excellent electron-attracting capacity of $\mathrm{C}_{60}$. Meanwhile, the quantum yield of g- $\mathrm{C}_{3} \mathrm{~N}_{4} /$ graphene $/ \mathrm{C}_{60}$ reached $7.2 \%$ within $72 \mathrm{~h}$.
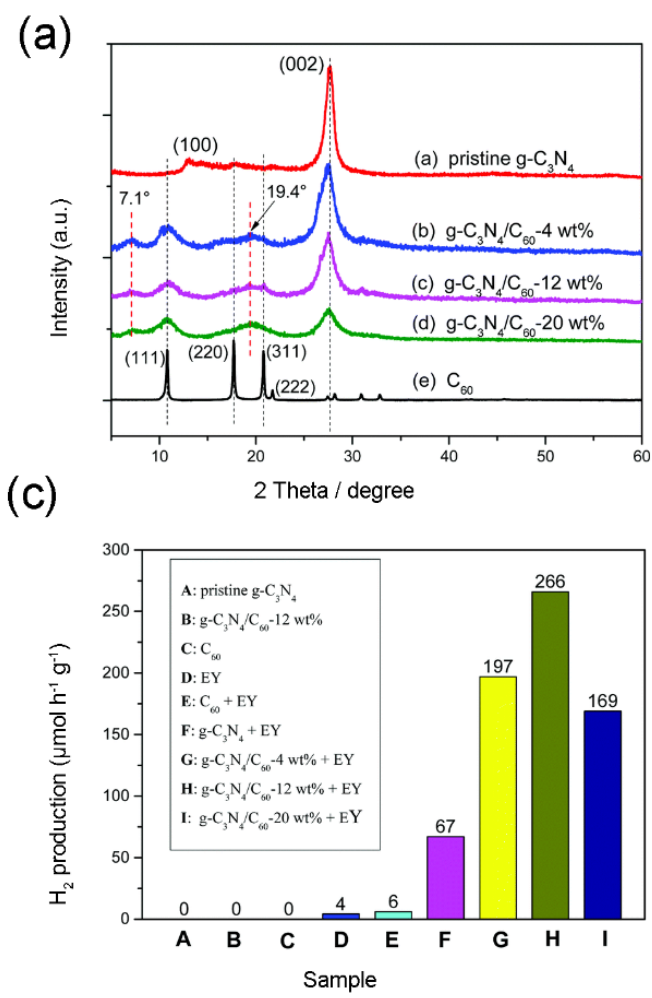

(b)

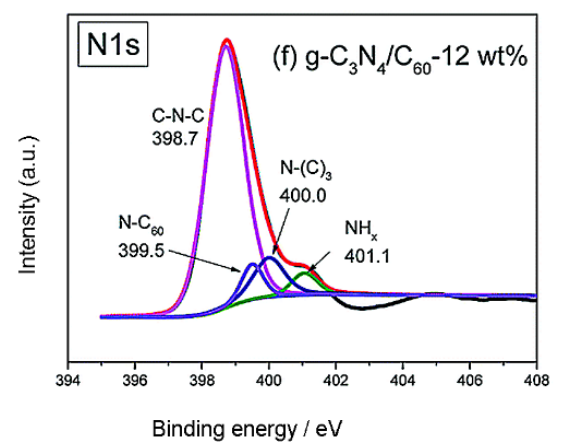

(d)

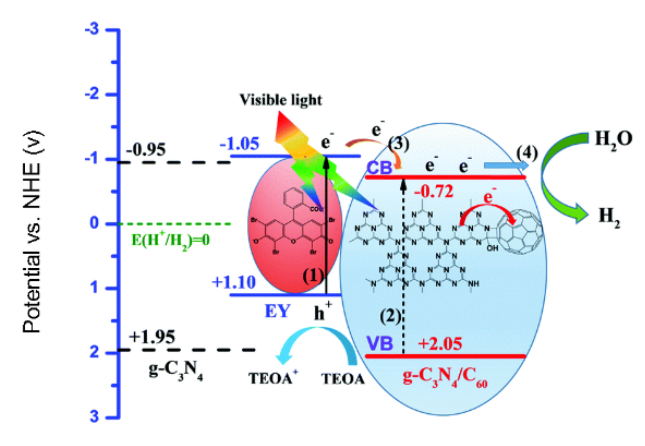

Figure 7. (a) $X R D$ patterns of g- $\mathrm{C}_{3} \mathrm{~N}_{4} / \mathrm{C}_{60}$ samples and pristine $\mathrm{g}-\mathrm{C}_{3} \mathrm{~N}_{4}$. (b) High-resolution $\mathrm{N}$ 1s XPS spectra of g- $\mathrm{C}_{3} \mathrm{~N}_{4} / \mathrm{C}_{60}-12 \mathrm{wt} \%$ nanocomposite. (c) Photocatalytic $\mathrm{H}_{2}$ generation rates of the as-prepared samples. (d) A schematic of the photocatalytic $\mathrm{H}_{2}$ generation mechanism for the $\mathrm{g}^{-} \mathrm{C}_{3} \mathrm{~N}_{4} / \mathrm{C}_{60}$ nanocomposite. Reproduced with permission from Reference [55]. Copyright 2017, RCS.

\subsection{Other Semiconductor/Fullerene Photocatalysts}

Other semiconductors have also been coupled with fullerene to boost the photocatalytic activity. For example, Dai, Yao, Liu, Mohamed, Chen and Huang [50] successfully fabricated a $\mathrm{PbMoO}_{4}-\mathrm{C}_{60}$ photocatalyst via a hydrothermal method. After introduction of $\mathrm{C}_{60}$, no obvious change was visible in lattice structure of $\mathrm{PbMoO}_{4}$, but defects were observed on the surface of $\mathrm{PbMoO}_{4}$ (Figure $8 \mathrm{a}, \mathrm{b}$ ), which could be owed to the decreased crystallinity. As depicted in energy dispersive spectrometry (EDS), a great deal of $\mathrm{C}$ element was evenly dispersed on the surface of $\mathrm{PbMoO}_{4}-\mathrm{C}_{60}$ nanocomposite, which was regarded as a layer coating of $\mathrm{C}_{60}$ moiety (Figure $8 \mathrm{c}, \mathrm{d}$ ). Upon the attachment of the $\mathrm{C}_{60}$ moiety, the $\mathrm{PbMoO}_{4}-\mathrm{C}_{60}$ composite displayed obvious enhancement of both $\mathrm{UV}$ and visible light absorption (Figure 8e). Meanwhile, the $\mathrm{Eg}$ of $5.0 \mathrm{wt} \% \mathrm{PbMoO}_{4}-\mathrm{C}_{60}(3.08 \mathrm{eV})$ was narrower than that of pure $\mathrm{PbMoO}_{4}(2.93 \mathrm{eV})$ (Figure 8f). Therefore, the improvement of optical features and energy band structure contributed to highly photocatalytic efficiency. Song, Yang, Chen and Zhang [72] prepared $\mathrm{Ag}_{3} \mathrm{PO}_{4} / \mathrm{C}_{60}$ photocatalyst via a simple chemical precipitation method. The photodegradation efficiency of $\mathrm{MO}$ achieved $93.5 \%$ within 8 min of visible light illumination. It is noteworthy that the introduction of $\mathrm{C}_{60}$ significantly enhanced the stabilization of $\mathrm{Ag}_{3} \mathrm{PO}_{4}$ which was usually susceptible to photo-corrosion. Additionally, some organic semiconductor nanoparticles composing of fullerene exhibited superior photocatalytic performance. For example, Huo and Zeng [86] successfully fabricated a triphenylamine functionalized bithiazole metal complex hybridized $\mathrm{C}_{60}$ photocatalyst. Under visible light irradiation, the photocatalytic $\mathrm{H}_{2}$ evolution of the as-prepared photocatalyst showed approximately 4-6-times higher than that of the pristine complex without fullerene. In this photocatalytic system, the organic 
metal nanocomposite worked as two roles which were both a photosensitizer and a photocatalyst. Additionally, Zhang, et al. [127] prepared an organic photocatalyst of fullerene hydrolyzed aluminum phthalocyanine chloride $\left(\mathrm{AlPc} / \mathrm{C}_{60}\right)$ by a reprecipitation method. The photocatalyst showed superior photooxidation degradation of various organic compounds (including N-methyl-2-pyrrolidone (NMP), methanal, and 2-mercaptoethanol). Note that the $\mathrm{AlPc} / \mathrm{C}_{60}$ exhibited highly efficiency in complete mineralization towards these organic materials, leading to effective $\mathrm{CO}_{2}$ generation in reaction solution under visible light irradiation. NMP mineralization experiment was tested in a closed cylindrical reactor containing $10 \mathrm{vol} \%$ substrate, wherein the $\mathrm{CO}_{2}$ generation amount in $\mathrm{AlPc} / \mathrm{C}_{60}$ reacting solution reached $3.7 \times 10^{-7}$ mol after $24 \mathrm{~h}$ irradiation, which was 2.9-times higher than that of the corresponding $\mathrm{C}_{60}+\mathrm{AlPc}$ mechanical mixture in solution. It was proposed that this novel photocatalyst based on a biphase structure and features $p / \mathrm{n}$ junction-like characteristics.
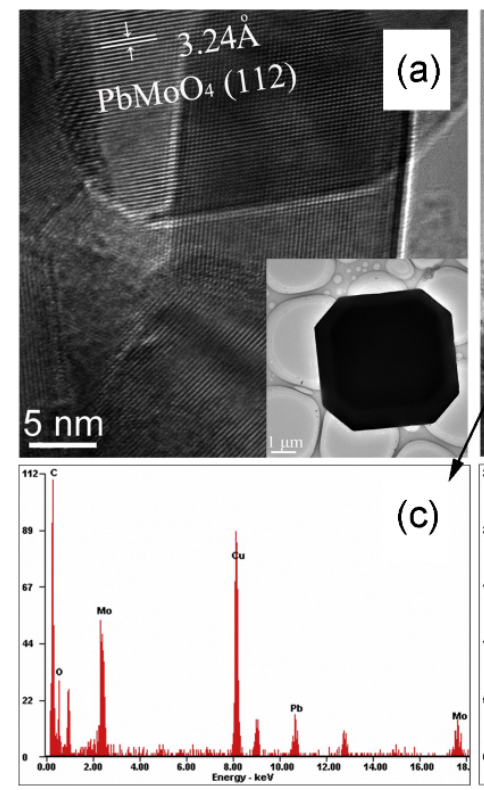

(c)

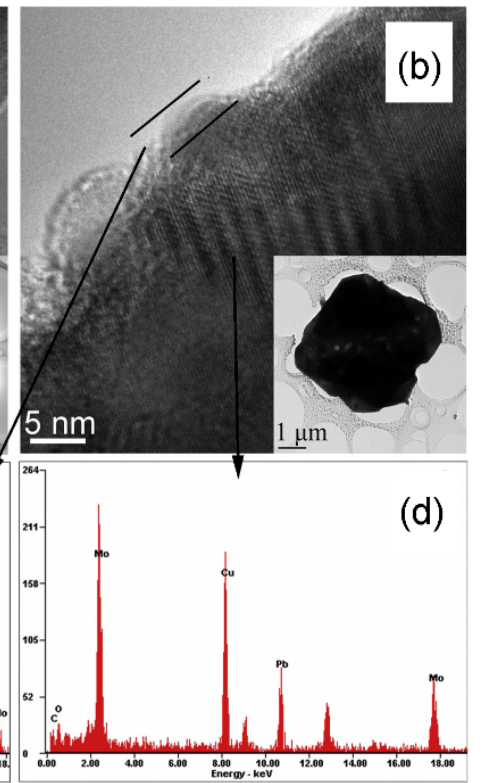

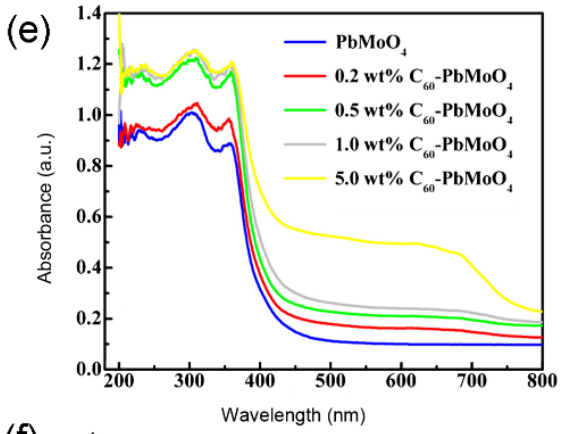

(f)

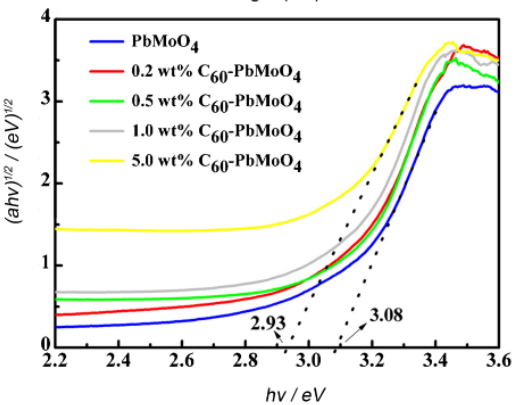

Figure 8. HRTEM images of $\mathrm{PbMoO}_{4}(\mathbf{a})$ and $\mathrm{C}_{60}-\mathrm{PbMoO}_{4}(\mathbf{b})$. EDS spectrum measured from the edge (c) and the center of $\mathrm{C}_{60}-\mathrm{PbMoO}_{4}$ composite (d). (e) DRS of the $\mathrm{C}_{60}-\mathrm{PbMoO}_{4}$ samples and pure $\mathrm{PbMoO}_{4}$ composite. (f) Plot of $(\alpha \mathrm{h} v)^{1 / 2}$ versus photon energy $(\mathrm{h} v)$ based on the DRS. Reproduced with permission from Reference [50]. Copyright 2013, Elsevier.

\subsection{Discussions and Conclusions for Photocatalytic Applications of Fullerene/Semiconductor Photocatalysts}

Among fullerene-based photocatalysts, the $\mathrm{TiO}_{2} /$ fullerene $\left(\mathrm{C}_{60}\right.$ and $\left.\mathrm{C}_{70}\right)$ composites have been the most extensively investigated in photocatalytic applications in the past decades. They exhibit efficient performances in wastewater treatment, such as pollutant degradation and disinfection. The synthetic methods are facile and eco-friendly without complicated steps, generally including simple adsorption and hydrothermal synthesis. After fullerene is inserted into $\mathrm{TiO}_{2}$, it shows to be fairly helpful in enhancing the photocatalytic efficiency of $\mathrm{TiO}_{2}$. However, there is a small deficiency in these materials, namely insufficient utilization of light energy. In other words, they exhibit excellent absorption of UV light but moderate absorption of visible light, while UV irradiation only accounts for $4 \%$ in solar irradiation. Besides, metal sulfide/fullerene nanocomposites are an appealing class of photocatalysts for not only decontamination but water splitting for $\mathrm{H}_{2}$ generation. They exhibit efficient absorption of visible light together with a moderate stability, such as $\mathrm{CdS} / \mathrm{C}_{60}, \mathrm{MoS}_{2}$ and $\mathrm{CdS} / \mathrm{TiO}_{2} / \mathrm{C}_{60}$. Compared with the responding pure metal sulfide, they perform significantly boosted efficiency, especially towards $\mathrm{H}_{2}$ generation. As to Bi-based semiconductor/fullerene photocatalysts, they appear to only be helpful for pollutant degradation but have not displayed effective capacity 
for photocatalytic $\mathrm{H}_{2}$ generation. There is no doubt that $\mathrm{g}-\mathrm{C}_{3} \mathrm{~N}_{4}$ has always been one of the hot nanomaterials in photocatalytic area since advent, so g- $\mathrm{C}_{3} \mathrm{~N}_{4} /$ fullerene photocatalysts are promising options for further photocatalysis. The facile synthetic method makes them attractive materials for photocatalytic applications, such as simple thermal treatment and balling mill. Additionally, it is easy to achieve more intensively oxidation or reduction capacity with tunable bandgap of g- $\mathrm{C}_{3} \mathrm{~N}_{4}$.

To sum up, three crucial characteristics of photocatalysts are needed to be considered for wastewater treatment, such as high-efficiency for removing pollutant, stability in duration and nontoxicity to the environment and humans, respectively. In order to convincingly evaluate a photocatalyst, it is required to concern various properties comprehensively, such as optical absorption, energy band, photocatalytic efficiency, stability, cost and so on. As we all know, photocatalytic applications are currently researched in the laboratory, which seldom involves the time consumption of process and economic efficiency. Future work is imperative to focus on these aspects.

\section{Fullerene/Support (Non-Semiconductor) Photocatalysts for Wastewater Treatment}

In addition to fullerene/semiconductor photocatalysts, a series of novel fullerene/solid-support photocatalysts have been developed for wastewater treatment. It is well established that pristine fullerene is extremely insoluble in water (solubility of $C_{60}$ in water $<10^{-9} \mathrm{mg} / \mathrm{L}$ ), but could dissolve in nonpolar organic solvent, such as toluene and 1,2-dichlorobenzen [128,129]. It is worthwhile mentioning that fullerene solution could induce photochemical reactive oxygen species (ROS) generation via two pathways which were defined as type I pathway (Equation (13)) and type II pathway (Equation (14)), taking $\mathrm{C}_{60}$ as an example as follows [22]. For example, single oxygen ${ }^{1} \mathrm{O}_{2}$ can be produced in fullerene-toluene solution (pathway II), and $\mathrm{O}_{2}{ }^{-\bullet}$ and $\bullet \mathrm{OH}$ can be generated in solvent in the present of electron donors such as EDTA and NADH (pathway I) under UV light illumination [130,131]. While easily aggregation of pristine fullerene in water impedes ROS production owing to self-quenching mechanisms within the aggregates [132,133]. It has been proven that coupling fullerene with hydrophilic functional groups (namely fullerene derivatives) is a helpful strategy to dissolve fullerene in water together with superior ROS generation, such as polyhydroxyl-fullerene, amine-fullerene and other cationic-fullerenes [134-136]. At the earlier time, these water-soluble fullerene derivatives were used as photosensitizers for photodynamic therapy, selective antimicrobial and photooxidation organic synthesis $[27,137]$. More recently, considerable research efforts have been devoted to wastewater treatment for fullerene-support photocatalysts, including photocatalytic pollutant degradation and disinfection in aqueous solution. Without support combination, aqueous fullerene $\left(\mathrm{nC}_{60}\right)$ and fullerene derivatives in aqueous solution are easily decomposed due to photolysis and other external conditions, seriously lowering efficacy of $\mathrm{C}_{60}$ as a photocatalyst generating ROS $[138,139]$. The separation and reutilization are also the barriers of fullerene derivatives used as photocatalysts. Herein, immobilization of fullerene-derivatives on solid support could be a hopeful strategy to fabricate fullerene/solid-support photocatalyst.

$$
\begin{array}{r}
{ }^{1} C_{60} \stackrel{h v}{\rightarrow}{ }^{1} C_{60}^{*} \stackrel{I S C}{\rightarrow} C^{*} C_{60}^{*} \stackrel{{ }^{3} \mathrm{O}_{2} \rightarrow^{1} \mathrm{O}_{2}}{\rightarrow} C_{60} \\
{ }^{1} C_{60} \stackrel{h v}{\rightarrow}{ }^{1} C_{60}^{*} \stackrel{I S C}{\rightarrow}{ }^{3} C_{60}^{*} \stackrel{e^{-}-\text {donor }}{\rightarrow} C_{60}^{-} \bullet \\
E_{\text {red }}=+1.14 V
\end{array}
$$

Lee, et al. [140] fabricated a series of amino $C_{60} /$ silica photocatalysts by covalent-bond immobilization of amino $\mathrm{C}_{60}$ on 3-(2-succinic anhydride) propyl functionalized silica gel. The synthesis route of the aminoC $\mathrm{C}_{60} /$ silica photocatalysts is presented in Figure 9. In this photocatalytic system, phosphate buffer was required for pollutant degradation and ${ }^{1} \mathrm{O}_{2}$ generated by photochemical procedure was the dominating ROS for photocatalytic activity. The photochemical ${ }^{1} \mathrm{O}_{2}$ generation ability of the as-prepared photocatalysts were estimated using furfuryl alcohol (FFA) as an indicator and immobilized amino $\mathrm{C}_{60}$ samples exhibited remarkedly higher ${ }^{1} \mathrm{O}_{2}$ generation than water-soluble 
amino $\mathrm{C}_{60}$, among which tetrakis amino $\mathrm{C}_{60} /$ silica performed the best (Figure 10a). Accordingly, these amino $\mathrm{C}_{60} /$ silica photocatalysts boosted the photocatalytic oxidation degradation towards pharmaceutical pollutants (including ranitidine and cimetidine) as well as photocatalytic disinfection towards MS-2 bacteriophage upon visible light illumination in contrast to corresponding amino $\mathrm{C}_{60}$ alone in aqueous solution. In this case, the immobilization method facilitated well dispersion of $\mathrm{C}_{60}$ onto the silica surface, so as to expose more active sites for ROS generation, resulting in enhancement of the photocatalytic efficiency. Additionally, the huge specific surface area of silica significantly enhanced the adsorption of pollutant to the surface of aminoC $60 /$ silica for promoting closer contact between ${ }^{1} \mathrm{O}_{2}$ and the pollutant, because the travel distance of ${ }^{1} \mathrm{O}_{2}$ in aqueous is really short within the diffusion length of $\sim 125 \mathrm{~nm}$ over one lifetime [141]. Note that the lifetime of ${ }^{1} \mathrm{O}_{2}$ in water was only $3 \sim 4 \mu \mathrm{s}$ which limits the catalytic performance, so immobilization of amino $\mathrm{C}_{60}$ could increase the contact time between ${ }^{1} \mathrm{O}_{2}$ and the pollutant from this point of view [142]. In order to further explore the performance of the tetrakis amino $\mathrm{C}_{60}$ /silica photocatalyst, a variety of emerging organic contaminants and endocrine disruptors were involved into photocatalytic degradation experiments [143]. The photodegradation rate of ranitidine and propranolol for amino silica/ $C_{60}$ were $13.987 \pm 0.016 \mathrm{~h}^{-1}$ and $10.77 \pm 0.019 \mathrm{~h}^{-1}$, which were respectively 31 -fold and 75 -fold faster than that for aimno $\mathrm{C}_{60}$ alone. In particular, the silica/amino $\mathrm{C}_{60}$ was quite effective in trimethoprim degradation while no degradation appeared in amino $\mathrm{C}_{60}$ aqueous solution, which was also observed in a $\mathrm{C}_{60}$ aminofullerene-magnetite nanocomposite suspension solution [144]. Moreover, at alkaline conditions ( $\mathrm{pH} 10)$, acetaminophen, bisphenol A, and 4-chlorophenol could also be effectively degraded over the silica/amino $\mathrm{C}_{60}$ photocatalyst under fluorescent light irradiation. Figure $10 \mathrm{~b}, \mathrm{c}$ compares the photocatalytic efficiency of silica/amino $\mathrm{C}_{60}$ with other semiconductor photocatalysts including $\mathrm{TiO}_{2}, \mathrm{C}-\mathrm{TiO}_{2}$ and $\mathrm{Pt} / \mathrm{WO}_{3}$. It is shown that silica/aminoC $\mathrm{C}_{60}$ exhibits remarkedly higher ${ }^{1} \mathrm{O}_{2}$ generation rate over $\mathrm{TiO}_{2}$ and $\mathrm{C}-\mathrm{TiO}_{2}$ while it performs lower rate than $\mathrm{Pt} / \mathrm{WO}_{3}$ under fluorescent light or visible light irradiation. Note that the silica/amino $\mathrm{C}_{60}$ exhibits the best efficiency in pharmaceutical (RA and $\mathrm{CM}$ ) degradation among these materials under visible light irradiation. Although these photoactive catalysts in the comparisons take effect owing to different $\mathrm{ROS}$ generation (e.g., primarily ${ }^{1} \mathrm{O}_{2}$ upon aminoC $\mathrm{C}_{60}, \bullet \mathrm{OH}$ upon $\mathrm{TiO}_{2}$ and $\left.\mathrm{Pt} / \mathrm{WO}_{3}\right)$, it is indicated that silica/amino $\mathrm{C}_{60}$ has a potential for application as an alternative environmental photocatalyst.
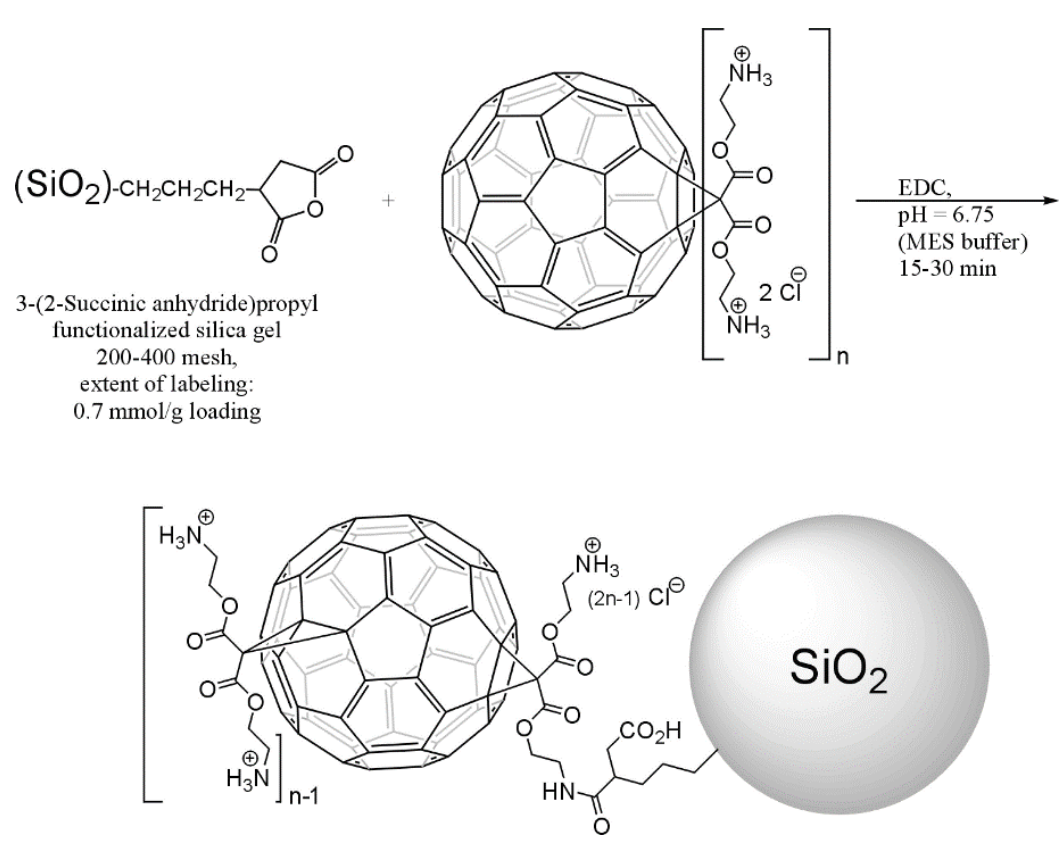

Figure 9. Route for immobilization of aminofullerenes on functionalized silica gel. Reproduced with permission from Reference [140]. Copyright 2010, ACS. 
(a)

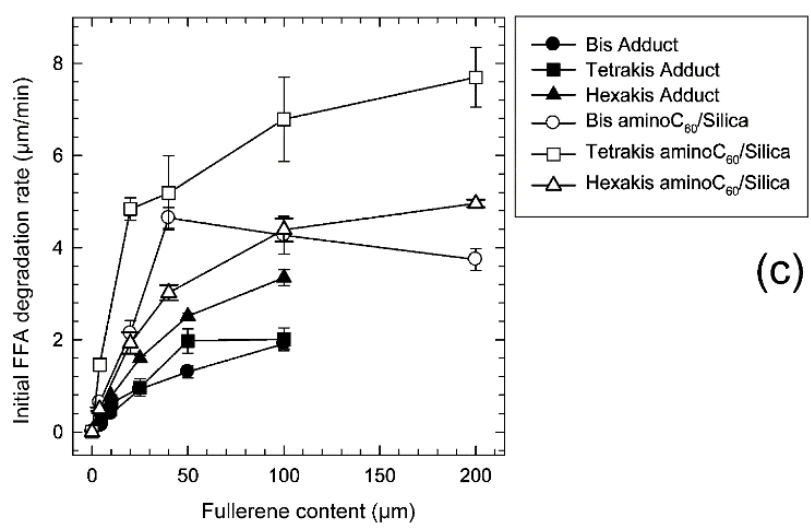

(b)

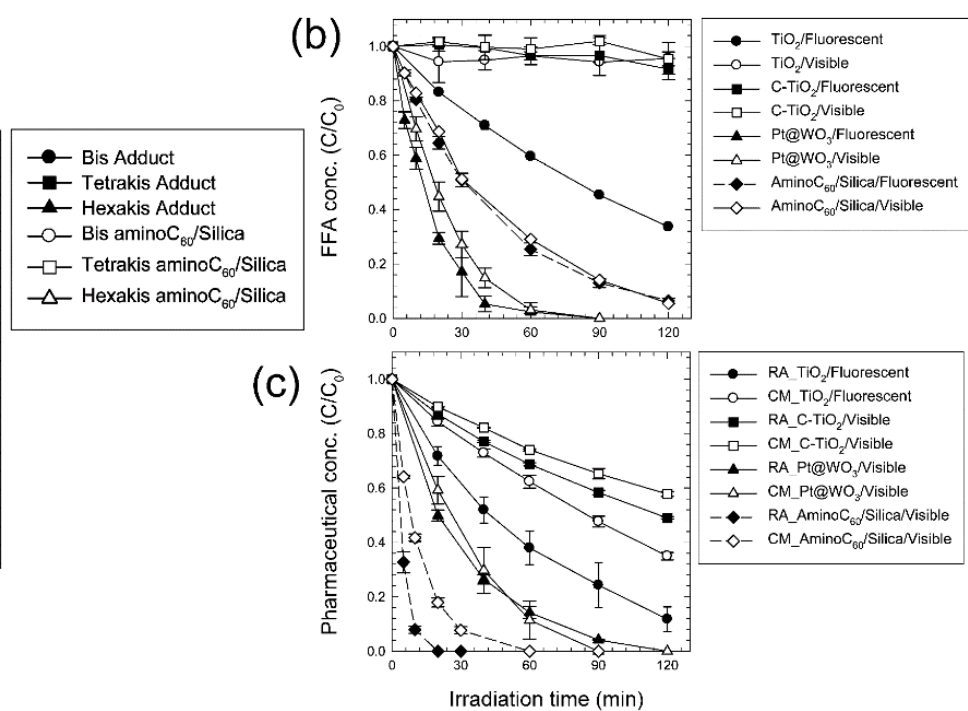

Figure 10. (a) Photochemical furfuryl alcohol (FFA) degradation (measuring photosensitized ${ }^{1} \mathrm{O}_{2}$ production) by aminofullerenes and aminofullerene/silica composites. Comparisons of degradation efficiency towards furfuryl alcohol (b) and ranitidine (RA) and cimetidine (CM) (c) by $\mathrm{TiO}_{2}$, carbon-doped $\mathrm{TiO}_{2}\left(\mathrm{C}-\mathrm{TiO}_{2}\right), \mathrm{Pt}_{\mathrm{W}} \mathrm{WO}_{3}$ and tetrakis aminoC $\mathrm{C}_{60} /$ silica. Reproduced with permission from Reference [140,143]. Copyright 2010, 2011, ACS.

There is no denying that aforementioned fullerene/solid photocatalysts are involved into complicated synthesis procedure with fullerene derivatives. Moor and Kim [145] used a simpler method to build solid supported $\mathrm{C}_{60}$ photocatalysts via a nucleophilic reaction of a terminal amine onto pristine $\mathrm{C}_{60^{\prime}} \mathrm{s}$ cage, and through this method $\mathrm{SiO}_{2} / \mathrm{C}_{60}$ and polystyrene resin/ $\mathrm{C}_{60}\left(\mathrm{PS} / \mathrm{C}_{60}\right)$ were developed. The above two photocatalysts both showed higher ${ }^{1} \mathrm{O}_{2}$ generation rate than $\mathrm{nC}_{60}$ (nanoscale aggregates) in aqueous solution under various illumination conditions, in which the $\mathrm{SiO}_{2} / \mathrm{C}_{60}$ was superior to $\mathrm{PS} / \mathrm{C}_{60}$. As a photosensitization catalyst, $\mathrm{SiO}_{2} / \mathrm{C}_{60}$ showed effectively photocatalytic MS2 inactivation, which was ascribed to ${ }^{1} \mathrm{O}_{2}$-mediated oxidization damage effect. In addition, Moor, Valle, $\mathrm{Li}$ and Kim [91] successfully fabricated a MCM- $41 / \mathrm{C}_{70}$ composite by the same nucleophilic reaction and it was the first time to use $\mathrm{C}_{70}$-solid support photocatalyst for wastewater treatment (Figure 11a). Within photoinactivation experiment towards MS2, the MCM- $41 / \mathrm{C}_{70}$ performed obviously higher efficiency than $\mathrm{N}-\mathrm{TiO}_{2}$ nanocomposite, which efficiently induced $\bullet \mathrm{OH}$ production in aqueous solution for microbial inactivation (Figure $11 \mathrm{~b}, \mathrm{c}$ ). It was confirmed that the as-prepared novel $\mathrm{MCM}-41 / \mathrm{C}_{70}$ photocatalyst exhibited efficient photodegradation ability to several pharmaceuticals and personal care products (PPCP), including bisphenol A, 17- $\alpha$-ethynylestradiol and amoxicillin (Figure 11d,e).

The majority of photocatalysts researched for traditional azo-dye decomposition based upon semiconductor composites. Few studies involved into non-semiconducting materials, especially $\mathrm{C}_{60} /$ solid support photocatalyst [146]. Whereas, Wakimoto, et al. [147] prepared a $\mathrm{SiO}_{2} / \mathrm{C}_{60}$ powder via a simple adsorption using pristine $\mathrm{C}_{60}$ and silica gel in toluene and it was important to highlight that a novel route for dye photodegradation was proposed for the $\mathrm{C}_{60} /$ solid support photocatalyst. Unlike typically semiconductor photocatalysts, the $\mathrm{SiO}_{2} / \mathrm{C}_{60}$ composite exhibited effectively visible-light-driven photocatalytic degradation towards methyl orange in the presence ascorbic acid, while $\mathrm{SiO}_{2} / \mathrm{C}_{60}$ alone without ascorbic acid did not show degradation performance. In this case, ascorbic acid could protonate $\mathrm{MO}$ and transform it into quinoid form with strong electron-acceptability. It was proved that both ${ }^{1} \mathrm{O}_{2}$ and $\mathrm{O}_{2}{ }^{\bullet-}$ species took part in the dye degradation. On one hand, $\mathrm{C}_{60}$ dispersed onto silica surface was excited to undergo the intersystem crossing from the single to triplet state for ${ }^{1} \mathrm{O}_{2}$ generating, then the generated ${ }^{1} \mathrm{O}_{2}$ could attack rich-electron quinoid structure to decompose $\mathrm{MO}$. On the other hand, the electron transferred from ascorbic acid to the excited $\mathrm{C}_{60}$ to forming the $\mathrm{C}_{60}$ radical anion, followed by generation of $\mathrm{O}_{2}{ }^{\bullet-}$ via $\mathrm{O}_{2}$ receiving the electron from $\mathrm{C}_{60}{ }^{\bullet}$, wherein $\mathrm{O}_{2}{ }^{\bullet-}$ was an effective specie for 
dye degradation. It was also confirmed that methyl red could be decomposed by $\mathrm{SiO}_{2} / \mathrm{C}_{60}$ at the same conditions. Likewise, Kyriakopoulos, et al. [148] successfully fabricated a MCM- $41 / \mathrm{C}_{60}$ photocatalyst via a dry impregnation method. Coupling $\mathrm{C}_{60}$ with MCM-41 significantly increased the BET of the as-prepared photocatalyst, thus effectively dispersing $\mathrm{C}_{60}$ clusters as well as strengthening its adsorption ability to pollutant. The optimum $3 \mathrm{MCM}-41 / \mathrm{C}_{60}\left(3 \mathrm{wt} \% \mathrm{C}_{60}\right)$ sample showed $74.9 \%$ decolorization efficiency in Orange $\mathrm{G}$, which was markedly higher than that of $\mathrm{C}_{60}$ alone. This photocatalyst proved to be remarkably stable, wherein less than $5 \%$ photodegradation efficiency was lost after five cycles.

(a)

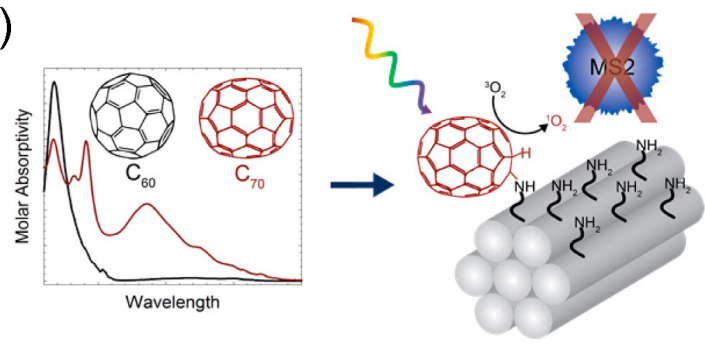

(b)

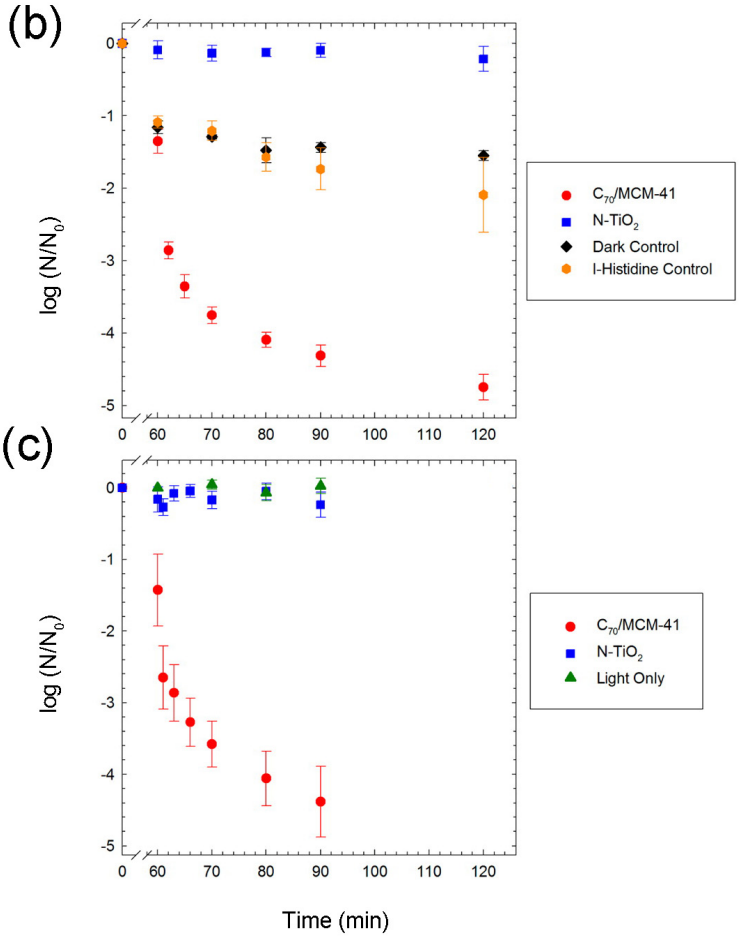

(d)

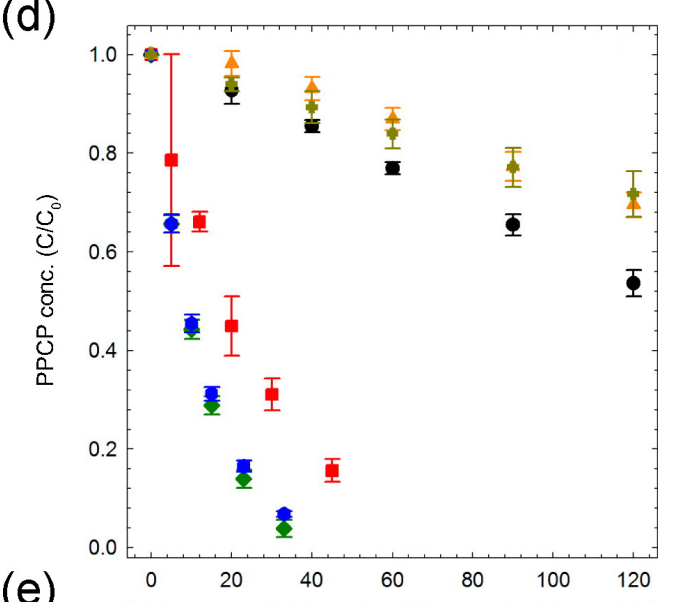

(e)

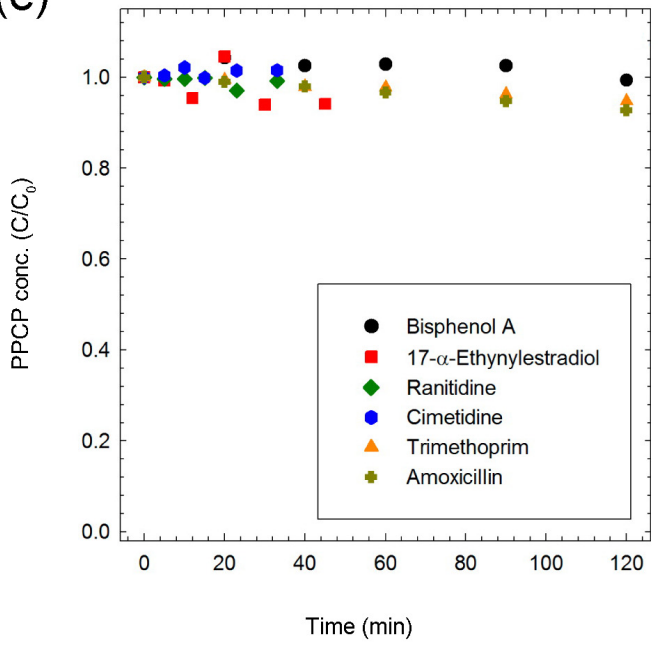

Figure 11. (a) A schematic of photocatalytic mechanism of novel $C_{70} / M C M-41$ photocatalyst. Photoinduced MS2 inactivation kinetics of $\mathrm{C}_{70} / \mathrm{MCM}-41$ and porous $\mathrm{N}-\mathrm{TiO}_{2}$ under visible light (b) and sunlight irradiation (c). Photodegradation kinetics of various PPCPs by $\mathrm{C}_{70} / \mathrm{MCM}-41$ under visible irradiation (d) and corresponding dark controls (e). Reproduced with permission from Reference [91]. Copyright 2015, ACS.

Fullerene-based solid photocatalysts could effectively prevent fullerene aggregations and enhance the photo-stabilization of fullerene alone as well as enhance the pollutant adsorption due to the introduced support, thus leading to increase the photocatalytic efficiency. In the meanwhile, this fullerene-based photocatalyst could perform selected oxidization of pollutant with ${ }^{1} \mathrm{O}_{2}$ that can prevent natural organic matter (NOM) interference, which underline the potential of these materials for wastewater treatment in natural water. Therefore, fullerene-based support photocatalysts are promising materials for environmental applications and further effort will be required to fabricate novel photocatalysts of this type. 


\section{Conclusions and Perspectives}

In summary, the essence of photocatalysis bases on the ROS generation in the presence of light resource irradiation. Fullerenes, including $C_{60}$ and $C_{70}$, have been extensively investigated in the photocatalytic application due to their unique optical and photochemical characteristics. Fullerene could be anchored on semiconductors to enhance their photocatalytic activity, and also supported on non-semiconductor solids to fabricate novel fullerene-based photocatalysts due to its self-photocatalytic features. In the present review, fullerene/semiconductor photocatalysts and fullerene-solid support photocatalysts are summarized for wastewater treatment (pollutant degradation, $\mathrm{Cr}(\mathrm{VI})$ reduction, disinfection etc.) and water splitting for $\mathrm{H}_{2}$ generation. A number of synthesis methods have been used to fabricate semiconductor/fullerene photocatalysts, including simple adsorption, hydrothermal synthesis, ball milling, sol-gel and so on. The semiconductors alone usually display limited photocatalytic performance, wherein the fast recombination of photoinduced hole-electron pairs and inefficient light energy utilization are the two main obstacles. Whereas, fullerene could availably enhance the photocatalytic efficiency of semiconductors by retarding the recombination of hole-electron pairs and increasing the light absorption ( $U V$ and visible light). In some cases, semiconductor/fullerene photocatalysts display better stabilization than semiconductors alone, and the introduced fullerene increases the BET of the semiconductor for enhancing the pollutant adsorption. The studies manifest that excess fullerene inhibits the photocatalytic ability due to the coverage effect towards excited sites. So, a suitable amount of fullerene is imperative for superior photocatalytic activity of semiconductor/fullerene photocatalysts. Plentiful semiconductors have been coupled with fullerene for wastewater treatment and water splitting, such as $\mathrm{TiO}_{2}, \mathrm{ZnO}, \mathrm{CdS}$ and $\mathrm{C}_{3} \mathrm{~N}_{4}$. The photocatalytic effect of these photocatalysts are presented and the involved mechanisms are discussed in detail in this review, including the reaction of ROS generation and the transfer route of electron. On the other hand, fullerene-solid support photocatalysts are also discussed in application for wastewater treatment, such as silica/ $\mathrm{C}_{60}, \mathrm{MCM}-41 / \mathrm{C}_{70}$ and polysiloxane-supported fullerene photocatalyst. They display excellent photoinduced ROS (mainly ${ }^{1} \mathrm{O}_{2}$ ) generation in aqueous solution after fullerene was dispersed onto the solid support, which is the direct factor contributing to the photocatalytic reaction. Meanwhile, they effectively enhance the photo-stabilization of fullerene alone as well as enhance the pollutant adsorption. It is noteworthy that these fullerene-based photocatalysts perform selected oxidization of the pollutant, wherein the photoinduced ${ }^{1} \mathrm{O}_{2}$ could prevent natural organic matter (NOM) interference. So, it underlines the potential of these materials for wastewater treatment in natural water.

Although some encouraging properties have been achieved for fullerene-based photocatalysts, the development of fullerene-based photocatalysts still has remaining challenges. (1) The interface contact between the fullerene and semiconductor is not so intimate, leading to limiting the electron transport ability and photostability of semiconductor/fullerene photocatalysts. The majority of semiconductor/fullerene photocatalysts formed by simple adsorption and hydrothermal synthesis, while few studies confirmed the existence of covalent bond or other tight bond in them. (2) The photocatalytic mechanisms of fullerene/semiconductor photocatalysts are partly not clear. Some studies indicated that the electrons transfer from the semiconductor to the fullerene due to the strong electron-accepting ability of fullerene, while others deemed that the electrons transfer in the opposite direction. (3) Not enough research has been done on the novel fullerene/solid (non-semiconductor) photocatalysts, in which the selection of solid support is restricted to silica, MCM-41 and polysiloxane. (4) The majority of fullerene-based photocatalysts are investigated in the treatment of simulated wastewater with the artificial addition of a single pollutant, and actual industrial wastewater is rarely involved.

In our opinion, several directions are worthy of attention for fullerene-based photocatalysts in the future: (1) Innovative strategy should be developed to construct semiconductor/fullerene photocatalysts with efficient performance and high stability. (2) Further works should focus on mechanism studies of the semiconductor/fullerene composite, especially the electron-transfer path which is still in dispute. (3) More attention should be paid to fullerene derivatives, which are promising materials for developing 
novel fullerene-based photocatalysts. (4) The studying of fullerene-based photocatalysts on their actual performance in natural water, industrial wastewater and multi-polluted wastewater.

Author Contributions: Conceptualization, X.Y. and L.J.; writing—original draft preparation, S.Y.; writing—review and editing, T.X. and J.Z. All authors have read and agreed to the published version of the manuscript.

Funding: The authors gratefully acknowledge the financial support provided by the National Natural Science Foundation of China (No. 51739004, 21776066 and 71431006).

Conflicts of Interest: The authors declare no conflict of interest.

\section{References}

1. Pan, Y.; Yuan, X.; Jiang, L.; Yu, H.; Zhang, J.; Wang, H.; Guan, R.; Zeng, G. Recent advances in synthesis, modification and photocatalytic applications of micro/nano-structured zinc indium sulfide. Chem. Eng. J. 2018, 354, 407-431. [CrossRef]

2. Yi, H.; Qin, L.; Huang, D.; Zeng, G.; Lai, C.; Liu, X.; Li, B.; Wang, H.; Zhou, C.; Huang, F.; et al. Nano-structured bismuth tungstate with controlled morphology: Fabrication, modification, environmental application and mechanism insight. Chem. Eng. J. 2019, 358, 480-496. [CrossRef]

3. Fujishima, A.; Honda, K. Electrochemical Photolysis of Water at a Semiconductor Electrode. Nature 1972, 238, 37-38. [CrossRef]

4. Smazna, D.; Rodrigues, J.; Shree, S.; Postica, V.; Neubueser, G.; Martins, A.F.; Ben Sedrine, N.; Jena, N.K.; Siebert, L.; Schuett, F.; et al. Buckminsterfullerene hybridized zinc oxide tetrapods: Defects and charge transfer induced optical and electrical response. Nanoscale 2018, 10, 10050-10062. [CrossRef]

5. Zhang, W.; Wang, Y.; Wang, Z.; Zhong, Z.; Xu, R. Highly efficient and noble metal-free NiS/CdS photocatalysts for $\mathrm{H}_{2}$ evolution from lactic acid sacrificial solution under visible light. Chem. Commun. 2010, 46, 7631-7633. [CrossRef]

6. Luo, C.-Y.; Huang, W.-Q.; Xu, L.; Yang, Y.-C.; Li, X.; Hu, W.; Peng, P.; Huang, G.-F. Enhanced photocatalytic performance of an $\mathrm{Ag}_{3} \mathrm{PO}_{4}$ photocatalyst via fullerene modification: First-principles study. Phys. Chem. Chem. Phys. 2016, 18, 2878-2886. [CrossRef]

7. Obregón, S.; Caballero, A.; Colón, G. Hydrothermal synthesis of $\mathrm{BiVO}_{4}$ : Structural and morphological influence on the photocatalytic activity. Appl. Catal. B 2012, 117, 59-66. [CrossRef]

8. Yu, H.; Jiang, L.; Wang, H.; Huang, B.; Yuan, X.; Huang, J.; Zhang, J.; Zeng, G. Modulation of $\mathrm{Bi}_{2} \mathrm{MoO}_{6}$-Based Materials for Photocatalytic Water Splitting and Environmental Application: A Critical Review. Small 2019, 15, 1901008. [CrossRef] [PubMed]

9. Wang, H.; Yuan, X.; Wu, Y.; Zeng, G.; Dong, H.; Chen, X.; Leng, L.; Wu, Z.; Peng, L. In situ synthesis of In2S3@MIL-125(Ti) core-shell microparticle for the removal of tetracycline from wastewater by integrated adsorption and visible-light-driven photocatalysis. Appl. Catal. B 2016, 186, 19-29. [CrossRef]

10. Jiang, L.; Yuan, X.; Pan, Y.; Liang, J.; Zeng, G.; Wu, Z.; Wang, H. Doping of graphitic carbon nitride for photocatalysis: A reveiw. Appl. Catal. B 2017, 217, 388-406. [CrossRef]

11. Xiang, Q.; $\mathrm{Yu}, \mathrm{J}$; J Jaroniec, M. Synergetic Effect of $\mathrm{MoS}_{2}$ and Graphene as Cocatalysts for Enhanced Photocatalytic $\mathrm{H}_{2}$ Production Activity of $\mathrm{TiO}_{2}$ Nanoparticles. J. Am. Chem. Soc. 2012, 134, 6575-6578. [CrossRef] [PubMed]

12. Zong, X.; Han, J.; Ma, G.; Yan, H.; Wu, G.; Li, C. Photocatalytic $\mathrm{H}_{2}$ Evolution on CdS Loaded with $\mathrm{WS}_{2}$ as Cocatalyst under Visible Light Irradiation. J. Phys. Chem. C 2011, 115, 12202-12208. [CrossRef]

13. Yeh, T.-F.; Cihlář, J.; Chang, C.-Y.; Cheng, C.; Teng, H. Roles of graphene oxide in photocatalytic water splitting. Mater. Today 2013, 16, 78-84. [CrossRef]

14. Ge, J.; Zhang, Y.; Park, S.-J. Recent Advances in Carbonaceous Photocatalysts with Enhanced Photocatalytic Performances: A Mini Review. Materials 2019, 12, 1916. [CrossRef]

15. Gangu, K.K.; Maddila, S.; Jonnalagadda, S.B. A review on novel composites of MWCNTs mediated semiconducting materials as photocatalysts in water treatment. Sci. Total Environ. 2019, 646, 1398-1412. [CrossRef] [PubMed]

16. Luo, Y.; Heng, Y.; Dai, X.; Chen, W.; Li, J. Preparation and photocatalytic ability of highly defective carbon nanotubes. J. Solid State Chem. 2009, 182, 2521-2525. [CrossRef] 
17. Yeh, T.-F.; Syu, J.-M.; Cheng, C.; Chang, T.-H.; Teng, H. Graphite Oxide as a Photocatalyst for Hydrogen Production from Water. Adv. Funct. Mater. 2010, 20, 2255-2262. [CrossRef]

18. Krishnamoorthy, K.; Mohan, R.; Kim, S.J. Graphene oxide as a photocatalytic material. Appl. Phys. Lett. 2011, 98, 244101. [CrossRef]

19. Song, L.; Guo, C.; Li, T.; Zhang, S. C-60/graphene/g- $\mathrm{C}_{3} \mathrm{~N}_{4}$ composite photocatalyst and mutually-reinforcing synergy to improve hydrogen production in splitting water under visible light radiation. Ceram. Int. 2017, 43, 7901-7907. [CrossRef]

20. Li, Q.; Xu, L.; Luo, K.W.; Huang, W.Q.; Wang, L.L.; Li, X.F.; Huang, G.F.; Yu, Y.B. Insights into enhanced visible-light photocatalytic activity of $\mathrm{C}_{60}$ modified g- $\mathrm{C}_{3} \mathrm{~N}_{4}$ hybrids: The role of nitrogen. Phys. Chem. Chem. Phys. 2016, 18, 33094-33102. [CrossRef]

21. Kumar, I.; Sharma, R.; Kumar, R.; Kumar, R.; Sharma, U. C-70 Fullerene-Catalyzed Metal-Free Photocatalytic ipso-Hydroxylation of Aryl Boronic Acids: Synthesis of Phenols. Adv. Synth. Catal. 2018, 360, 2013-2019. [CrossRef]

22. Yamakoshi, Y.; Umezawa, N.; Ryu, A.; Arakane, K.; Miyata, N.; Goda, Y.; Masumizu, T.; Nagano, T. Active Oxygen Species Generated from Photoexcited Fullerene $\left(\mathrm{C}_{60}\right)$ as Potential Medicines: $\mathrm{O}_{2}$-versus 1O2. J. Am. Chem. Soc. 2003, 125, 12803-12809. [CrossRef] [PubMed]

23. Panahian, Y.; Arsalani, N.; Nasiri, R. Enhanced photo and sono-photo degradation of crystal violet dye in aqueous solution by 3D flower like $\mathrm{F}-\mathrm{TiO}_{2}(\mathrm{~B}) /$ fullerene under visible light. J. Photochem. Photobiol. A Chem. 2018, 365, 45-51. [CrossRef]

24. Hu, Y.; Xie, X.; Wang, X.; Wang, Y.; Zeng, Y.; Pui, D.Y.H.; Sun, J. Visible-Light Upconversion Carbon Quantum Dots Decorated $\mathrm{TiO}_{2}$ for the Photodegradation of Flowing Gaseous Acetaldehyde. Appl. Surf. Sci. 2018, 440, 266-274. [CrossRef]

25. Cho, B.H.; Lee, K.B.; Miyazawa, K.I.; Ko, W.B. Preparation of Fullerene (C-60) Nanowhisker-ZnO Nanocomposites by Heat Treatment and Photocatalytic Degradation of Methylene Blue. Asian J. Chem. 2013, 25, 8027-8030. [CrossRef]

26. Panagiotou, G.D.; Tzirakis, M.D.; Vakros, J.; Loukatzikou, L.; Orfanopoulos, M.; Kordulis, C.; Lycourghiotis, A. Development of 60 fullerene supported on silica catalysts for the photo-oxidation of alkenes. Appl. Catal. A Gen. 2010, 372, 16-25. [CrossRef]

27. Latassa, D.; Enger, O.; Thilgen, C.; Habicher, T.; Offermanns, H.; Diederich, F. Polysiloxane-supported fullerene derivative as a new heterogeneous sensitiser for the selective photooxidation of sulfides to sulfoxides by 1O2. J. Mater. Chem. 2002, 12, 1993-1995. [CrossRef]

28. Manjon, F.; Santana-Magana, M.; Garcia-Fresnadillo, D.; Orellana, G. Are silicone-supported [C60]-fullerenes an alternative to $\mathrm{Ru}(\mathrm{II})$ polypyridyls for photodynamic solar water disinfection? Photochem. Photobiol. Sci. 2014, 13, 397-406. [CrossRef]

29. Guan, G.; Ye, E.; You, M.; Li, Z. Hybridized 2D Nanomaterials Toward Highly Efficient Photocatalysis for Degrading Pollutants: Current Status and Future Perspectives. Small 2020, 16, 1907087. [CrossRef]

30. Perovic, K.; Dela Rosa, F.M.; Kovacic, M.; Kusic, H.; Lavrencic Stangar, U.; Fresno, F.; Dionysiou, D.D.; Bozic, A.L. Recent Achievements in Development of $\mathrm{TiO}_{2}$-Based Composite Photocatalytic Materials for Solar Driven Water Purification and Water Splitting. Materials 2020, 13, 1338. [CrossRef]

31. Xu, T.; Zhu, R.; Zhu, J.; Liang, X.; Zhu, G.; Liu, Y.; Xu, Y.; He, H. Fullerene modification of $\mathrm{Ag}_{3} \mathrm{PO}_{4}$ for the visible-light-driven degradation of acid red 18. RSC Adv. 2016, 6, 85962-85969. [CrossRef]

32. Sepahvand, S.; Farhadi, S. Preparation and characterization of fullerene (C-60)-modified $\mathrm{BiVO}_{4} / \mathrm{Fe}_{3} \mathrm{O}_{4}$ nanocomposite by hydrothermal method and study of its visible light photocatalytic and catalytic activity. Fuller. Nanotub. Carbon Nanostruct. 2018, 26, 417-432. [CrossRef]

33. Virovska, D.; Paneva, D.; Manolova, N.; Rashkov, I.; Karashanova, D. Photocatalytic self-cleaning poly(L-lactide) materials based on a hybrid between nanosized zinc oxide and expanded graphite or fullerene. Mater. Sci. Eng. C Mater. Biol. Appl. 2016, 60, 184-194. [CrossRef] [PubMed]

34. Ding, S.-S.; Huang, W.-Q.; Zhou, B.-X.; Peng, P.; Hu, W.-Y.; Long, M.-Q.; Huang, G.-F. The mechanism of enhanced photocatalytic activity of $\mathrm{SnO}_{2}$ through fullerene modification. Curr. Appl. Phys. 2017, 17, 1547-1556. [CrossRef]

35. Bai, X.; Wang, L.; Wang, Y.; Yao, W.; Zhu, Y. Enhanced oxidation ability of $g-\mathrm{C}_{3} \mathrm{~N}_{4}$ photocatalyst via C60 modification. Appl. Catal. B 2014, 153, 262-270. [CrossRef] 
36. Meng, Z.-D.; Zhu, L.; Oh, W.-C. Preparation and high visible-light-induced photocatalytic activity of CdSe and CdSe-C-60 nanoparticles. J. Ind. Eng. Chem. 2012, 18, 2004-2009. [CrossRef]

37. Luo, C.-Y.; Huang, W.-Q.; Hu, W.; Peng, P.; Huang, G.-F. Non-covalent functionalization of WS W $_{2}$ monolayer with small fullerenes: Tuning electronic properties and photoactivity. Dalton Trans. 2016, 45, 13383-13391. [CrossRef]

38. Ju, L.; Wu, P.; Lai, X.; Yang, S.; Gong, B.; Chen, M.; Zhu, N. Synthesis and characterization of Fullerene modified ZnAlTi-LDO in photo-degradation of Bisphenol A under simulated visible light irradiation. Environ. Pollut. 2017, 228, 234-244. [CrossRef]

39. Ma, D.; Zhong, J.; Li, J.; Wang, L.; Peng, R. Enhanced photocatalytic activity of BiOCl by C-70 modification and mechanism insight. Appl. Surf. Sci. 2018, 443, 497-505. [CrossRef]

40. Zhu, S.; Xu, T.; Fu, H.; Zhao, J.; Zhu, Y. Synergetic effect of $\mathrm{Bi}_{2} \mathrm{WO}_{6}$ photocatalyst with C-60 and enhanced photoactivity under visible irradiation. Environ. Sci. Technol. 2007, 41, 6234-6239. [CrossRef]

41. Aich, N.; Flora, J.; Saleh, N. Preparation and characterization of stable aqueous higher-order fullerenes. Nanotechnology 2012, 23, 55705. [CrossRef]

42. Sampaio, M.J.; Bacsa, R.R.; Benyounes, A.; Axet, R.; Serp, P.; Silva, C.G.; Silva, A.M.T.; Faria, J.L. Synergistic effect between carbon nanomaterials and $\mathrm{ZnO}$ for photocatalytic water decontamination. J. Catal. 2015, 331, 172-180. [CrossRef]

43. Cai, Q.; Hu, Z.; Zhang, Q.; Li, B.; Shen, Z. Fullerene (C-60)/CdS nanocomposite with enhanced photocatalytic activity and stability. Appl. Surf. Sci. 2017, 403, 151-158. [CrossRef]

44. Prylutskyy, Y.I.; Petrenko, V.I.; Ivankov, O.I.; Kyzyma, O.A.; Bulavin, L.A.; Litsis, O.O.; Evstigneev, M.P.; Cherepanov, V.V.; Naumovets, A.G.; Ritter, U. On the Origin of $\mathrm{C}_{60}$ Fullerene Solubility in Aqueous Solution. Langmuir 2014, 30, 3967-3970. [CrossRef] [PubMed]

45. Chai, B.; Liao, X.; Song, F.; Zhou, H. Fullerene modified $\mathrm{C}_{3} \mathrm{~N}_{4}$ composites with enhanced photocatalytic activity under visible light irradiation. Dalton Trans. 2014, 43, 982-989. [CrossRef] [PubMed]

46. Zhao, X.; Liu, H.; Shen, Y.; Qu, J. Photocatalytic reduction of bromate at C60 modified Bi2MoO6 under visible light irradiation. Appl. Catal. B 2011, 106, 63-68. [CrossRef]

47. Zhang, L.; Wang, Y.; Xu, T.; Zhu, S.; Zhu, Y. Surface hybridization effect of C60 molecules on $\mathrm{TiO}_{2}$ and enhancement of the photocatalytic activity. J. Mol. Catal. A Chem. 2010, 331, 7-14. [CrossRef]

48. Yu, J.; Ma, T.; Liu, G.; Cheng, B. Enhanced photocatalytic activity of bimodal mesoporous titania powders by C-60 modification. Dalton Trans. 2011, 40, 6635-6644. [CrossRef] [PubMed]

49. Ouyang, K.; Dai, K.; Walker, S.L.; Huang, Q.; Yin, X.; Cai, P. Efficient Photocatalytic Disinfection of Escherichia coli O157:H7 using C-70-TiO 2 Hybrid under Visible Light Irradiation. Sci. Rep. 2016, 6, 25702. [CrossRef]

50. Dai, K.; Yao, Y.; Liu, H.; Mohamed, I.; Chen, H.; Huang, Q. Enhancing the photocatalytic activity of lead molybdate by modifying with fullerene. J. Mol. Catal. A Chem. 2013, 374, 111-117. [CrossRef]

51. Lin, X.; Xi, Y.; Zhao, R.; Shi, J.; Yan, N. Construction of C-60-decorated SWCNTs (C-60-CNTs)/bismuth-based oxide ternary heterostructures with enhanced photocatalytic activity. RSC Adv. 2017, 7, 53847-53854. [CrossRef]

52. Meng, Z.-D.; Zhu, L.; Ullah, K.; Ye, S.; Sun, Q.; Jang, W.K.; Oh, W.-C. Study of the photochemically generated of oxygen species by fullerene photosensitized $\mathrm{CoS}_{2}$ nanocompounds. Mater. Res. Bull. 2014, 49, $272-278$. [CrossRef]

53. Tahir, M.B.; Nabi, G.; Rafique, M.; Khalid, N.R. Role of fullerene to improve the WO3 performance for photocatalytic applications and hydrogen evolution. Int. J. Energy Res. 2018, 42, 4783-4789. [CrossRef]

54. Guan, J.; Wu, J.; Jiang, D.; Zhu, X.; Guan, R.; Lei, X.; Du, P.; Zeng, H.; Yang, S. Hybridizing MoS2 and C-60 via a van der Waals heterostructure toward synergistically enhanced visible light photocatalytic hydrogen production activity. Int. J. Hydrog. Energy 2018, 43, 8698-8706. [CrossRef]

55. Chen, X.; Chen, H.; Guan, J.; Zhen, J.; Sun, Z.; Du, P.; Lu, Y.; Yang, S. A facile mechanochemical route to a covalently bonded graphitic carbon nitride $\left(\mathrm{g}-\mathrm{C}_{3} \mathrm{~N}_{4}\right)$ and fullerene hybrid toward enhanced visible light photocatalytic hydrogen production. Nanoscale 2017, 9, 5615-5623. [CrossRef]

56. Meng, Z.-D.; Peng, M.-M.; Zhu, L.; Oh, W.-C.; Zhang, F.-J. Fullerene modification $\mathrm{CdS}_{\mathrm{TiO}} 2$ to enhancement surface area and modification of photocatalytic activity under visible light. Appl. Catal. B Environ. 2012, 113, 141-149. [CrossRef]

57. Li, J.; Ko, W.B. Facile Synthesis of MoS2-C60Nanocomposites and Their Application to Catalytic Reduction and Photocatalytic Degradation. Elastom. Compos. 2016, 51, 286-300. [CrossRef] 
58. Apostolopoulou, V.; Vakros, J.; Kordulis, C.; Lycourghiotis, A. Preparation and characterization of 60 fullerene nanoparticles supported on titania used as a photocatalyst. Colloids Surf. A Physicochem. Eng. Asp. 2009, 349, 189-194. [CrossRef]

59. Hamandi, M.; Berhault, G.; Dappozze, F.; Guillard, C.; Kochkar, H. Titanium dioxide nanotubes/polyhydroxyfullerene composites for formic acid photodegradation. Appl. Surf. Sci. 2017, 412, 306-318. [CrossRef]

60. Donar, Y.O.; Bilge, S.; Sinag, A.; Pliekhov, O. $\mathrm{TiO}_{2} /$ Carbon Materials Derived from Hydrothermal Carbonization of Waste Biomass: A Highly Efficient, Low-Cost Visible-Light-Driven Photocatalyst. Chemcatchem 2018, 10, 1134-1139. [CrossRef]

61. Mu, S.; Long, Y.; Kang, S.-Z.; Mu, J. Surface modification of $\mathrm{TiO}_{2}$ nanoparticles with a C60 derivative and enhanced photocatalytic activity for the reduction of aqueous $\mathrm{Cr}(\mathrm{VI})$ ions. Catal. Commun. 2010, 11, 741-744. [CrossRef]

62. Zhao, Z.; An, H.; Lin, J.; Feng, M.; Murugadoss, V.; Ding, T.; Liu, H.; Shao, Q.; Mai, X.; Wang, N.; et al. Progress on the Photocatalytic Reduction Removal of Chromium Contamination. Chem. Rec. 2019, 19, 873-882. [CrossRef] [PubMed]

63. Lü, X.-F.; Qian, H.; Mele, G.; De Riccardis, A.; Zhao, R.; Chen, J.; Wu, H.; Hu, N.-J. Impact of different $\mathrm{TiO}_{2}$ samples and porphyrin substituents on the photocatalytic performance of $\mathrm{TiO}_{2} @$ copper porphyrin composites. Catal. Today 2017, 281, 45-52. [CrossRef]

64. Hashimoto, K.; Irie, H.; Fujishima, A. $\mathrm{TiO}_{2}$ Photocatalysis: A Historical Overview and Future Prospects. Jpn. J. Appl. Phys. 2005, 44, 8269-8285. [CrossRef]

65. Fujishima, A.; Zhang, X.; Tryk, D.A. $\mathrm{TiO}_{2}$ photocatalysis and related surface phenomena. Surf. Sci. Rep. 2008, 63, 515-582. [CrossRef]

66. Youssef, Z.; Colombeau, L.; Yesmurzayeva, N.; Baros, F.; Vanderesse, R.; Hamieh, T.; Toufaily, J.; Frochot, C.; Roques-Carmes, T.; Acherar, S. Dye-sensitized nanoparticles for heterogeneous photocatalysis: Cases studies with $\mathrm{TiO}_{2}, \mathrm{ZnO}$, fullerene and graphene for water purification. Dyes Pigm. 2018, 159, 49-71. [CrossRef]

67. Oh, W.-C.; Jung, A.-R.; Ko, W.-B. Preparation of fullerene $/ \mathrm{TiO}_{2}$ composite and its photocatalytic effect. J. Ind. Eng. Chem. 2007, 13, 1208-1214.

68. Zhang, X.; Wang, Q.; Zou, L.-H.; You, J.-W. Facile fabrication of titanium dioxide/fullerene nanocomposite and its enhanced visible photocatalytic activity. J. Colloid Interface Sci. 2016, 466, 56-61. [CrossRef]

69. Wang, S.; Liu, C.; Dai, K.; Cai, P.; Chen, H.; Yang, C.; Huang, Q. Fullerene C-70-TiO 2 hybrids with enhanced photocatalytic activity under visible light irradiation. J. Mater. Chem. A 2015, 3, 21090-21098. [CrossRef]

70. Fu, H.; Xu, T.; Zhu, S.; Zhu, Y. Photocorrosion Inhibition and Enhancement of Photocatalytic Activity for ZnO via Hybridization with C-60. Environ. Sci. Technol. 2008, 42, 8064-8069. [CrossRef]

71. Behera, A.; Mansingh, S.; Das, K.K.; Parida, K. Synergistic $\mathrm{ZnFe}_{2} \mathrm{O}_{4}$-carbon allotropes nanocomposite photocatalyst for norfloxacin degradation and Cr (VI) reduction. J. Colloid Interface Sci. 2019, 544, 96-111. [CrossRef] [PubMed]

72. Song, L.; Yang, J.; Chen, Q.; Zhang, S. Enhanced photocatalytic activity of $\mathrm{Ag}_{3} \mathrm{PO}_{4}$ via Fullerene C-60 modification. Appl. Organomet. Chem. 2018, 32, e4472. [CrossRef]

73. Li, G.; Jiang, B.; Li, X.; Lian, Z.; Xiao, S.; Zhu, J.; Zhang, D.; Li, H. C-60/Bi $2 \mathrm{TiO}_{4} \mathrm{~F}_{2}$ Heterojunction Photocatalysts with Enhanced Visible-Light Activity for Environmental Remediation. ACS Appl. Mater. Interface 2013, 5, 7190-7197. [CrossRef] [PubMed]

74. Sepahvand, S.; Farhadi, S. Fullerene-modified magnetic silver phosphate $\left(\mathrm{Ag}_{3} \mathrm{PO}_{4} / \mathrm{Fe}_{3} \mathrm{O}_{4} / \mathrm{C}-60\right)$ nanocomposites: Hydrothermal synthesis, characterization and study of photocatalytic, catalytic and antibacterial activities. RSC Adv. 2018, 8, 10124-10140. [CrossRef]

75. Meng, Z.-D.; Zhu, L.; Choi, J.-G.; Chen, M.-L.; Oh, W.-C. Effect of Pt treated fullerene/TiO ${ }_{2}$ on the photocatalytic degradation of MO under visible light. J. Mater. Chem. 2011, 21, 7596-7603. [CrossRef]

76. Meng, Z.-D.; Zhang, F.-J.; Zhu, L.; Park, C.-Y.; Ghosh, T.; Choi, J.-G.; Oh, W.-C. Synthesis and characterization of $\mathrm{M}$-fullerene/TiO 2 photocatalysts designed for degradation azo dye. Mater. Sci. Eng. C Mater. Biol. Appl. 2012, 32, 2175-2182. [CrossRef]

77. Islam, M.T.; Hangkun, J.; Ting, Y.; Zubia, E.; Goos, A.G.; Bernal, R.A.; Botez, C.E.; Narayan, M.; Chan, C.K.; Noveron, J.C. Fullerene stabilized gold nanoparticles supported on titanium dioxide for enhanced photocatalytic degradation of methyl orange and catalytic reduction of 4-nitrophenol. J. Environ. Chem. Eng. 2018, 6, 3827-3836. [CrossRef] 
78. Meng, Z.-D.; Zhu, L.; Choi, J.-G.; Park, C.-Y.; Oh, W.-C. Preparation, characterization and photocatalytic behavior of $\mathrm{WO}_{3}$-fullerene/TiO 2 catalysts under visible light. Nanoscale Res. Lett. 2011, 6, 459. [CrossRef]

79. Ali, M.M.; Sandhya, K.Y. Visible light responsive titanium dioxide-cyclodextrin-fullerene composite with reduced charge recombination and enhanced photocatalytic activity. Carbon 2014, 70, 249-257. [CrossRef]

80. Bai, W.; Krishna, V.; Wang, J.; Moudgil, B.; Koopman, B. Enhancement of nano titanium dioxide photocatalysis in transparent coatings by polyhydroxy fullerene. Appl. Catal. B Environ. 2012, 125, 128-135. [CrossRef]

81. Lim, J.; Monllor-Satoca, D.; Jang, J.S.; Lee, S.; Choi, W. Visible light photocatalysis of fullerol-complexed $\mathrm{TiO}_{2}$ enhanced by $\mathrm{Nb}$ doping. Appl. Catal. B 2014, 153, 233-240. [CrossRef]

82. Song, T.; Huo, J.; Liao, T.; Zeng, J.; Qin, J.; Zeng, H. Fullerene C-60 modified $\mathrm{Cr}_{2}-\mathrm{xFexO}_{3}$ nanocomposites for enhanced photocatalytic activity under visible light irradiation. Chem. Eng. J. 2016, 287, 359-366. [CrossRef]

83. Song, T.; Zhang, P.; Zeng, J.; Wang, T.; Ali, A.; Zeng, H. Boosting the photocatalytic H-2 evolution activity of $\mathrm{Fe}_{2} \mathrm{O}_{3}$ polymorphs (alpha-, gamma- and beta- $\mathrm{Fe}_{2} \mathrm{O}_{3}$ ) by fullerene C-60 -modification and dye-sensitization under visible light irradiation. RSC Adv. 2017, 7, 29184-29192. [CrossRef]

84. Lian, Z.; Xu, P.; Wang, W.; Zhang, D.; Xiao, S.; Li, X.; Li, G. C-60-Decorated CdS/TiO 2 Mesoporous Architectures with Enhanced Photostability and Photocatalytic Activity for H-2 Evolution. ACS Appl. Mater. Interface 2015, 7, 4533-4540. [CrossRef]

85. Chai, B.; Peng, T.; Zhang, X.; Mao, J.; Li, K.; Zhang, X. Synthesis of C-60-decorated SWCNTs (C-60-d-CNTs) and its $\mathrm{TiO}_{2}$-based nanocomposite with enhanced photocatalytic activity for hydrogen production. Dalton Trans. 2013, 42, 3402-3409. [CrossRef] [PubMed]

86. Huo, J.; Zeng, H. A novel triphenylamine functionalized bithiazole-metal complex with C-60 for photocatalytic hydrogen production under visible light irradiation. J. Mater. Chem. A 2015, 3, 6258-6264. [CrossRef]

87. Shahzad, K.; Tahir, M.B.; Sagir, M. Engineering the performance of heterogeneous WO3/fullerene@ $\mathrm{Ni}_{3} \mathrm{~B} / \mathrm{Ni}(\mathrm{OH})_{2}$ Photocatalysts for Hydrogen Generation. Int. J. Hydrog. Energy 2019, 44, 21738-21745. [CrossRef]

88. Katsumata, K.-I.; Matsushita, N.; Okada, K. Preparation of $\mathrm{TiO}_{2}$-Fullerene Composites and Their Photocatalytic Activity under Visible Light. Int. J. Photoenergy 2012. [CrossRef]

89. Grandcolas, M.; Ye, J.; Miyazawa, K. Titania nanotubes and fullerenes C-60 assemblies and their photocatalytic activity under visible light. Ceram. Int. 2014, 40, 1297-1302. [CrossRef]

90. Bastakoti, B.P.; Ishihara, S.; Leo, S.-Y.; Ariga, K.; Wu, K.C.W.; Yamauchi, Y. Polymeric Micelle Assembly for Preparation of Large-Sized Mesoporous Metal Oxides with Various Compositions. Langmuir 2014, 30, 651-659. [CrossRef]

91. Moor, K.J.; Valle, D.C.; Li, C.; Kim, J.-H. Improving the Visible Light Photoactivity of Supported Fullerene Photocatalysts through the Use of C-70 Fullerene. Environ. Sci. Technol. 2015, 49, 6190-6197. [CrossRef] [PubMed]

92. Kumar, R.; Gleissner, E.H.; Tiu, E.G.; Yamakoshi, Y. C70 as a Photocatalyst for Oxidation of Secondary Benzylamines to Imines. Org. Lett. 2016, 18, 184-187. [CrossRef] [PubMed]

93. Arbogast, J.W.; Foote, C.S. Photophysical properties of C70. J. Am. Chem. Soc. 1991, 113, 8886-8889. [CrossRef]

94. Cho, E.-C.; Ciou, J.-H.; Zheng, J.-H.; Pan, J.; Hsiao, Y.-S.; Lee, K.-C.; Huang, J.-H. Fullerene C-70 decorated $\mathrm{TiO}_{2}$ nanowires for visible-light-responsive photocatalyst. Appl. Surf. Sci. 2015, 355, 536-546. [CrossRef]

95. Oh, W.-C.; Ko, W.-B. Characterization and photonic properties for the Pt-fullerene/ $\mathrm{TiO}_{2}$ composites derived from titanium (IV) n-butoxide and C-60. J. Ind. Eng. Chem. 2009, 15, 791-797. [CrossRef]

96. Kanchanatip, E.; Grisdanurak, N.; Thongruang, R.; Neramittagapong, A. Degradation of paraquat under visible light over fullerene modified $\mathrm{V}-T i O_{2}$. React. Kinet. Mech. Catal. 2011, 103, 227-237. [CrossRef]

97. Oh, W.-C.; Zhang, F.-J.; Chen, M.-L. Synthesis and characterization of V-C-60/TiO 2 photocatalysts designed for degradation of methylene blue. J. Ind. Eng. Chem. 2010, 16, 299-304. [CrossRef]

98. Meng, Z.-D.; Zhu, L.; Ye, S.; Sun, Q.; Ullah, K.; Cho, K.-Y.; Oh, W.-C. Fullerene modification CdSe/TiO 2 and modification of photocatalytic activity under visible light. Nanoscale Res. Lett. 2013, 8, 1-10. [CrossRef]

99. Pickering, K.D.; Wiesner, M.R. Fullerol-sensitized production of reactive oxygen species in aqueous solution. Environ. Sci. Technol. 2005, 39, 1359-1365. [CrossRef]

100. Schreiner, K.M.; Filley, T.R.; Blanchette, R.A.; Bowen, B.B.; Bolskar, R.D.; Hockaday, W.C.; Masiello, C.A.; Raebiger, J.W. White-Rot Basidiomycete-Mediated Decomposition of C60 Fullerol. Environ. Sci. Technol. 2009, 43, 3162-3168. [CrossRef] 
101. Vileno, B.; Marcoux, P.R.; Lekka, M.; Sienkiewicz, A.; Fehér, T.; Forró, L. Spectroscopic and Photophysical Properties of a Highly Derivatized C60 Fullerol. Adv. Funct. Mater. 2006, 16, 120-128. [CrossRef]

102. Husebo, L.O.; Sitharaman, B.; Furukawa, K.; Kato, T.; Wilson, L.J. Fullerenols revisited as stable radical anions. J. Am. Chem. Soc. 2004, 126, 12055-12064. [CrossRef] [PubMed]

103. Trajković, S.; Dobrić, S.; Jaćević, V.; Dragojević-Simić, V.; Milovanović, Z.; Đorđević, A. Tissue-protective effects of fullerenol $\mathrm{C}_{60}(\mathrm{OH})_{24}$ and amifostine in irradiated rats. Colloids Surf. B Biointerfaces 2007, 58, 39-43. [CrossRef] [PubMed]

104. Krishna, V.; Noguchi, N.; Koopman, B.; Moudgil, B. Enhancement of titanium dioxide photocatalysis by water-soluble fullerenes. J. Colloid Interface Sci. 2006, 304, 166-171. [CrossRef] [PubMed]

105. Krishna, V.; Yanes, D.; Imaram, W.; Angerhofer, A.; Koopman, B.; Moudgil, B. Mechanism of enhanced photocatalysis with polyhydroxy fullerenes. Appl. Catal. B 2008, 79, 376-381. [CrossRef]

106. Park, Y.; Singh, N.J.; Kim, K.S.; Tachikawa, T.; Majima, T.; Choi, W. Fullerol-Titania Charge-Transfer-Mediated Photocatalysis Working under Visible Light. Chem. A Eur. J. 2009, 15, 10843-10850. [CrossRef] [PubMed]

107. Seo, Y.S.; Lee, C.; Lee, K.H.; Yoon, K.B. 1:1 and 2:1 charge-transfer complexes between aromatic hydrocarbons and dry titanium dioxide. Angew. Chem. Int. Ed. Engl. 2005, 44, 910-913. [CrossRef]

108. Ramakrishnan, A.; Neubert, S.; Mei, B.; Strunk, J.; Wang, L.; Bledowski, M.; Muhler, M.; Beranek, R. Enhanced performance of surface-modified $\mathrm{TiO}_{2}$ photocatalysts prepared via a visible-light photosynthetic route. Chem. Commun. 2012, 48, 8556-8558. [CrossRef]

109. Velmurugan, R.; Swaminathan, M. An efficient nanostructured ZnO for dye sensitized degradation of Reactive Red 120 dye under solar light. Sol. Energy Mater. Sol. Cells 2011, 95, 942-950. [CrossRef]

110. Chen, D.; Ye, J. Hierarchical $\mathrm{WO}_{3}$ Hollow Shells: Dendrite, Sphere, Dumbbell, and Their Photocatalytic Properties. Adv. Funct. Mater. 2008, 18, 1922-1928. [CrossRef]

111. Xie, X.; Yang, H.; Zhang, F.; Li, L.; Ma, J.; Jiao, H.; Zhang, J. Synthesis of hollow microspheres constructed with $\alpha-\mathrm{Fe}_{2} \mathrm{O}_{3}$ nanorods and their photocatalytic and magnetic properties. J. Alloys Compd. 2009, 477, 90-99. [CrossRef]

112. Bae, K.W. Synthesis of $\mathrm{SnO}_{2}-\mathrm{Mn}-\mathrm{C} 60$ Nanocomposites and Their Photocatalytic Activity for Degradation of Organic Dyes. Elastom. Compos. 2017, 52, 287-294.

113. Di Paola, A.; Garcia-Lopez, E.; Marci, G.; Palmisano, L. A survey of photocatalytic materials for environmental remediation. J. Hazard. Mater. 2012, 211, 3-29. [CrossRef] [PubMed]

114. Hong, S.K.; Lee, J.H.; Cho, B.H.; Ko, W.B. Preparation of a 70 fullerene-ZnO nanocomposite in an electric furnace and photocatalytic degradation of organic dyes. J. Ceram. Process. Res. 2011, 12, $212-217$.

115. Chang, K.; Mei, Z.; Wang, T.; Kang, Q.; Ouyang, S.; Ye, J. MoS2/Graphene Cocatalyst for Efficient Photocatalytic H2 Evolution under Visible Light Irradiation. ACS Nano 2014, 8, 7078-7087. [CrossRef]

116. Yuan, X.; Wang, H.; Wang, J.; Zeng, G.; Chen, X.; Wu, Z.; Jiang, L.; Xiong, T.; Zhang, J.; Wang, H. Near-infrared-driven $\mathrm{Cr}(\mathrm{vi})$ reduction in aqueous solution based on a $\mathrm{MoS}_{2} / \mathrm{Sb}_{2} \mathrm{~S}_{3}$ photocatalyst. Catal. Sci. Technol. 2018, 8, 1545-1554. [CrossRef]

117. Yuan, X.; Jiang, L.; Liang, J.; Pan, Y.; Zhang, J.; Wang, H.; Leng, L.; Wu, Z.; Guan, R.; Zeng, G. In-situ synthesis of $3 \mathrm{D}$ microsphere-like $\mathrm{In}_{2} \mathrm{~S}_{3} / \mathrm{InVO}_{4}$ heterojunction with efficient photocatalytic activity for tetracycline degradation under visible light irradiation. Chem. Eng. J. 2019, 356, 371-381. [CrossRef]

118. Simon, T.; Bouchonville, N.; Berr, M.J.; Vaneski, A.; Adrović, A.; Volbers, D.; Wyrwich, R.; Döblinger, M.; Susha, A.S.; Rogach, A.L.; et al. Redox shuttle mechanism enhances photocatalytic $\mathrm{H}_{2}$ generation on Ni-decorated CdS nanorods. Nat. Mater. 2014, 13, 1013-1018. [CrossRef]

119. Meng, Z.-D.; Ghosh, T.; Zhu, L.; Choi, J.-G.; Park, C.-Y.; Oh, W.-C. Synthesis of fullerene modified with $\mathrm{Ag}_{2} \mathrm{~S}$ with high photocatalytic activity under visible light. J. Mater. Chem. 2012, 22, 16127-16135. [CrossRef]

120. Di, J.; Xia, J.; Ji, M.; Wang, B.; Yin, S.; Zhang, Q.; Chen, Z.; Li, H. Advanced photocatalytic performance of graphene-like $\mathrm{BN}$ modified $\mathrm{BiOBr}$ flower-like materials for the removal of pollutants and mechanism insight. Appl. Catal. B 2016, 183, 254-262. [CrossRef]

121. Yu, H.; Huang, B.; Wang, H.; Yuan, X.; Jiang, L.; Wu, Z.; Zhang, J.; Zeng, G. Facile construction of novel direct solid-state Z-scheme $\mathrm{AgI} / \mathrm{BiOBr}$ photocatalysts for highly effective removal of ciprofloxacin under visible light exposure: Mineralization efficiency and mechanisms. J. Colloid Interface Sci. 2018, 522, 82-94. [CrossRef]

122. Wang, X.; Maeda, K.; Thomas, A.; Takanabe, K.; Xin, G.; Carlsson, J.M.; Domen, K.; Antonietti, M. A metal-free polymeric photocatalyst for hydrogen production from water under visible light. Nat. Mater. 2009, 8, 76-80. [CrossRef] [PubMed] 
123. Jiang, L.; Yuan, X.; Zeng, G.; Liang, J.; Wu, Z.; Yu, H.; Mo, D.; Wang, H.; Xiao, Z.; Zhou, C. Nitrogen self-doped g- $\mathrm{C}_{3} \mathrm{~N}_{4}$ nanosheets with tunable band structures for enhanced photocatalytic tetracycline degradation. J. Colloid Interface Sci. 2019, 536, 17-29. [CrossRef] [PubMed]

124. Jiang, L.; Yuan, X.; Zeng, G.; Liang, J.; Wu, Z.; Wang, H.; Zhang, J.; Xiong, T.; Li, H. A facile band alignment of polymeric carbon nitride isotype heterojunctions for enhanced photocatalytic tetracycline degradation. Environ. Sci. Nano 2018, 5, 2604-2617. [CrossRef]

125. Wu, Y.; Wang, H.; Tu, W.; Wu, S.; Liu, Y.; Tan, Y.Z.; Luo, H.; Yuan, X.; Chew, J.W. Petal-like CdS nanostructures coated with exfoliated sulfur-doped carbon nitride via chemically activated chain termination for enhanced visible-light-driven photocatalytic water purification and H2 generation. Appl. Catal. B 2018, 229, 181-191. [CrossRef]

126. Ouyang, K.; Dai, K.; Chen, H.; Huang, Q.; Gao, C.; Cai, P. Metal-free inactivation of E. coli O157:H7 by fullerene/ $\mathrm{C}_{3} \mathrm{~N}_{4}$ hybrid under visible light irradiation. Ecotoxicol. Environ. Saf. 2017, 136, 40-45. [CrossRef]

127. Zhang, S.; Arunachalam, P.; Abe, T.; Iyoda, T.; Nagai, K. Photocatalytic decomposition of $\mathrm{N}$-methyl-2-pyrrolidone, aldehydes, and thiol by biphase and $\mathrm{p} / \mathrm{n}$ junction-like organic semiconductor composite nanoparticles responsive to nearly full spectrum of visible light. J. Photochem. Photobiol. A Chem. 2012, 244, 18-23. [CrossRef]

128. Ruoff, R.S.; Tse, D.S.; Malhotra, R.; Lorents, D.C. Solubility of fullerene (C60) in a variety of solvents. J. Phys. Chem. 1993, 97, 3379-3383. [CrossRef]

129. Kyriakopoulos, J.; Papastavrou, A.T.; Panagiotou, G.D.; Tzirakis, M.D.; Triantafyllidis, K.S.; Alberti, M.N.; Bourikas, K.; Kordulis, C.; Orfanopoulos, M.; Lycourghiotis, A. Deposition of fullerene C-60 on the surface of MCM-41 via the one-step wet impregnation method: Active catalysts for the singlet oxygen mediated photooxidation of alkenes. J. Mol. Catal. A Chem. 2014, 381, 9-15. [CrossRef]

130. Hou, W.-C.; Jafvert, C.T. Photochemistry of Aqueous C60 Clusters: Evidence of $1 \mathrm{O} 2$ Formation and its Role in Mediating C60 Phototransformation. Environ. Sci. Technol. 2009, 43, 5257-5262. [CrossRef] [PubMed]

131. Tzirakis, M.D.; Vakros, J.; Loukatzikou, L.; Amargianitakis, V.; Orfanopoulos, M.; Kordulis, C.; Lycourghiotis, A. Gamma-Alumina-supported 60 fullerene catalysts: Synthesis, properties and applications in the photooxidation of alkenes. J. Mol. Catal. A Chem. 2010, 316, 65-74. [CrossRef]

132. Lee, J.; Yamakoshi, Y.; Hughes, J.B.; Kim, J.-H. Mechanism of C60 Photoreactivity in Water: Fate of Triplet State and Radical Anion and Production of Reactive Oxygen Species. Environ. Sci. Technol. 2008, 42, 3459-3464. [CrossRef]

133. Hotze, E.M.; Labille, J.; Alvarez, P.; Wiesner, M.R. Mechanisms of Photochemistry and Reactive Oxygen Production by Fullerene Suspensions in Water. Environ. Sci. Technol. 2008, 42, 4175-4180. [CrossRef] [PubMed]

134. Vileno, B.; Sienkiewicz, A.; Lekka, M.; Kulik, A.J.; Forró, L. In vitro assay of singlet oxygen generation in the presence of water-soluble derivatives of C60. Carbon 2004, 42, 1195-1198. [CrossRef]

135. Cho, M.; Lee, J.; Mackeyev, Y.; Wilson, L.J.; Alvarez, P.J.J.; Hughes, J.B.; Kim, J.-H. Visible Light Sensitized Inactivation of MS-2 Bacteriophage by a Cationic Amine-Functionalized C60 Derivative. Environ. Sci. Technol. 2010, 44, 6685-6691. [CrossRef] [PubMed]

136. Snow, S.D.; Park, K.; Kim, J.-H. Cationic Fullerene Aggregates with Unprecedented Virus Photoinactivation Efficiencies in Water. Environ. Sci. Technol. Lett. 2014, 1, 290-294. [CrossRef]

137. Mroz, P.; Tegos, G.P.; Gali, H.; Wharton, T.; Sarna, T.; Hamblin, M.R. Photodynamic therapy with fullerenes. Photochem. Photobiol. Sci. 2007, 6, 1139-1149. [CrossRef]

138. Hou, W.-C.; Kong, L.; Wepasnick, K.A.; Zepp, R.G.; Fairbrother, D.H.; Jafvert, C.T. Photochemistry of Aqueous C60 Clusters: Wavelength Dependency and Product Characterization. Environ. Sci. Technol. 2010, 44, 8121-8127. [CrossRef]

139. Hou, W.-C.; Jafvert, C.T. Photochemical Transformation of Aqueous C60 Clusters in Sunlight. Environ. Sci. Technol. 2009, 43, 362-367. [CrossRef]

140. Lee, J.; Mackeyev, Y.; Cho, M.; Wilson, L.J.; Kim, J.-H.; Alvarez, P.J.J. C60 Aminofullerene Immobilized on Silica as a Visible-Light-Activated Photocatalyst. Environ. Sci. Technol. 2010, 44, 9488-9495. [CrossRef]

141. Redmond, R.W.; Kochevar, I.E. Symposium-in-Print: Singlet Oxygen Invited Review. Photochem. Photobiol. 2006, 82, 1178-1186. [CrossRef] 
142. Foote, C.S.; Clennan, E.L. Properties and Reactions of Singlet Dioxygen. In Active Oxygen in Chemistry; Foote, C.S., Valentine, J.S., Greenberg, A., Liebman, J.F., Eds.; Springer: Dordrecht, The Netherlands, 1995; pp. 105-140.

143. Lee, J.; Hong, S.; Mackeyev, Y.; Lee, C.; Chung, E.; Wilson, L.J.; Kim, J.H.; Alvarez, P.J. Photosensitized oxidation of emerging organic pollutants by tetrakis $C(6)(0)$ aminofullerene-derivatized silica under visible light irradiation. Environ. Sci. Technol. 2011, 45, 10598-10604. [CrossRef]

144. Choi, Y.; Ye, Y.; Mackeyev, Y.; Cho, M.; Lee, S.; Wilson, L.J.; Lee, J.; Alvarez, P.J.J.; Choi, W.; Lee, J. C60 aminofullerene-magnetite nanocomposite designed for efficient visible light photocatalysis and magnetic recovery. Carbon 2014, 69, 92-100. [CrossRef]

145. Moor, K.J.; Kim, J.H. Simple synthetic method toward solid supported c60 visible light-activated photocatalysts. Environ. Sci. Technol. 2014, 48, 2785-2791. [CrossRef] [PubMed]

146. Rogozea, E.A.; Meghea, A.; Olteanu, N.L.; Bors, A.; Mihaly, M. Fullerene-modified silica materials designed for highly efficient dyes photodegradation. Mater. Lett. 2015, 151, 119-121. [CrossRef]

147. Wakimoto, R.; Kitamura, T.; Ito, F.; Usami, H.; Moriwaki, H. Decomposition of methyl orange using C60 fullerene adsorbed on silica gel as a photocatalyst via visible-light induced electron transfer. Appl. Catal. B 2015, 166-167, 544-550. [CrossRef]

148. Kyriakopoulos, J.; Kordouli, E.; Bourikas, K.; Kordulis, C.; Lycourghiotis, A. Decolorization of Orange-G Aqueous Solutions over C-60/MCM-41 Photocatalysts. Appl. Sci. 2019, 9, 1958. [CrossRef]

(C) 2020 by the authors. Licensee MDPI, Basel, Switzerland. This article is an open access article distributed under the terms and conditions of the Creative Commons Attribution (CC BY) license (http://creativecommons.org/licenses/by/4.0/). 